University of Nebraska - Lincoln

DigitalCommons@University of Nebraska - Lincoln

U.S. Environmental Protection Agency Papers

U.S. Environmental Protection Agency

2007

\title{
Fundulus as the premier teleost model in environmental biology: Opportunities for new insights using genomics
}

\author{
Karen G. Burnett \\ College of Charleston, burnettk@cofc.edu \\ Lisa J. Bain \\ Clemson University \\ William S. Baldwin \\ Clemson University \\ Gloria V. Callard \\ Boston University \\ Sarah Cohen \\ San Francisco State University

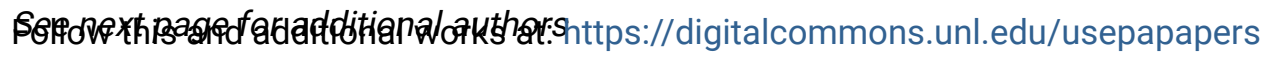 \\ Part of the Earth Sciences Commons, Environmental Health and Protection Commons, Environmental \\ Monitoring Commons, and the Other Environmental Sciences Commons
}

Burnett, Karen G.; Bain, Lisa J.; Baldwin, William S.; Callard, Gloria V.; Cohen, Sarah; Di Giulio, Richard T.; Evans, David H.; Gómez-Chiarri, Marta; Hahn, Mark E.; Hoover, Cindi A.; Karchner, Sibel I.; Katoh, Fumi; MacLatchy, Deborah L.; Marshall, William S.; Meyer, Joel N.; Nacci, Diane E.; Oleksiak, Marjorie F.; Rees, Bernard B.; Singer, Thomas D.; Stegeman, John J.; Towle, David W.; Van Veld, Peter A.; Vogelbein, Wolfgang K.; Whitehead, Andrew; Winn, Richard N.; and Crawford, Douglas L., "Fundulus as the premier teleost model in environmental biology: Opportunities for new insights using genomics" (2007). U.S. Environmental Protection Agency Papers. 98.

https://digitalcommons.unl.edu/usepapapers/98

This Article is brought to you for free and open access by the U.S. Environmental Protection Agency at DigitalCommons@University of Nebraska - Lincoln. It has been accepted for inclusion in U.S. Environmental Protection Agency Papers by an authorized administrator of DigitalCommons@University of Nebraska - Lincoln. 


\section{Authors}

Karen G. Burnett, Lisa J. Bain, William S. Baldwin, Gloria V. Callard, Sarah Cohen, Richard T. Di Giulio, David H. Evans, Marta Gómez-Chiarri, Mark E. Hahn, Cindi A. Hoover, Sibel I. Karchner, Fumi Katoh, Deborah L. MacLatchy, William S. Marshall, Joel N. Meyer, Diane E. Nacci, Marjorie F. Oleksiak, Bernard B. Rees, Thomas D. Singer, John J. Stegeman, David W. Towle, Peter A. Van Veld, Wolfgang K. Vogelbein, Andrew Whitehead, Richard N. Winn, and Douglas L. Crawford 


\title{
Fundulus as the premier teleost model in environmental biology: Opportunities for new insights using genomics
}

\author{
Karen G. Burnett ${ }^{\mathrm{a}, *}$, Lisa J. Bain ${ }^{\mathrm{b}}$, William S. Baldwin ${ }^{\mathrm{b}}$, Gloria V. Callard ${ }^{\mathrm{c}}$, Sarah Cohen ${ }^{\mathrm{d}}$, \\ Richard T. Di Giulio ${ }^{\text {e }}$, David H. Evans ${ }^{\text {f }}$, Marta Gómez-Chiarri ${ }^{\mathrm{g}}$, Mark E. Hahn ${ }^{\mathrm{h}}$, \\ Cindi A. Hoover ${ }^{c}$, Sibel I. Karchner ${ }^{\text {h}}$, Fumi Katoh ${ }^{j}$, Deborah L. MacLatchy ${ }^{i}$,
}

William S. Marshall ${ }^{\mathrm{j}}$, Joel N. Meyer ${ }^{\mathrm{e}}$, Diane E. Nacci ${ }^{\mathrm{k}}$, Marjorie F. Oleksiak ${ }^{1}$, Bernard B. Rees ${ }^{\mathrm{m}}$, Thomas D. Singer ${ }^{\mathrm{n}}$, John J. Stegeman ${ }^{\mathrm{h}}$, David W. Towle ${ }^{\mathrm{o}}$, Peter A. Van Veld ${ }^{\mathrm{p}}$, Wolfgang K. Vogelbein ${ }^{p}$, Andrew Whitehead ${ }^{\mathrm{q}}$, Richard N. Winn ${ }^{\mathrm{r}}$, Douglas L. Crawford ${ }^{1}$

\author{
${ }^{a}$ Grice Marine Laboratory, College of Charleston, Charleston, SC 29412, USA \\ ${ }^{\mathrm{b}}$ Clemson Institute of Environmental Toxicology, Clemson University; Pendleton, SC 29670, USA \\ ${ }^{\mathrm{c}}$ Department of Biology, Boston University, Boston, MA, USA \\ ${ }^{\mathrm{d}}$ Romberg Tiburon Center and Department of Biology, San Francisco State University, Tiburon, CA 94120, USA \\ ${ }^{\mathrm{e}}$ Nicholas School of the Environment and Earth Sciences, Duke University, Durham, NC, USA \\ ${ }^{\mathrm{f}}$ Department of Zoology, University of Florida, Gainesville, FL 32611, USA \\ ${ }^{\mathrm{g}}$ Department of Fisheries, Animal and Veterinary Science, University of Rhode Island, Kingston, RI 02881, USA \\ ${ }^{\mathrm{h}}$ Biology Department, Woods Hole Oceanographic Institution, Woods Hole, MA 02543, USA \\ ${ }^{\mathrm{i}}$ Faculty of Science, Wilfred Laurier University, Waterloo, Ontario, Canada N2L 3C5 \\ ${ }^{\mathrm{j}}$ Department of Biology, St. Francis Xavier University, Antigonish, N.S., Canada B2G 2W5 \\ ${ }^{k}$ US Environmental Protection Agency Office of Research and Development, Narragansett, RI 02882, USA \\ ${ }^{1}$ Rosenstiel School of Marine \& Atmospheric Science, University of Miami, Miami, FL 33149, USA \\ ${ }^{\mathrm{m}}$ Department of Biological Sciences, University of New Orleans, New Orleans, LA 70148, USA \\ ${ }^{\mathrm{n}}$ School of Optometry, University of Waterloo, Waterloo, ON, Canada N2L $3 G 1$ \\ ${ }^{\circ}$ Center for Marine Functional Genomics, Mount Desert Island Biological Laboratory, Salsbury Cove, Maine 04672, USA \\ ${ }^{\mathrm{p}}$ The College of William and Mary, Virginia Institute of Marine Science, Gloucester Point, VA 23062, USA \\ ${ }^{\mathrm{q}}$ Department of Biological Sciences, Louisiana State University, Baton Rouge, LA 70803, USA \\ ${ }^{\mathrm{r}}$ Aquatic Biotechnology and Environmental Laboratory, University of Georgia, Athens, GA 30602, USA
}

Received 25 April 2007; received in revised form 31 August 2007; accepted 1 September 2007 Available online 8 September 2007

\footnotetext{
Abbreviations: AHR, Aryl hydrocarbon receptor; AHRR, AHR repressor; ANF, $\alpha$-naphthoflavone; ARNT, AHR nuclear translocator; BAC, Bacterial artificial chromosome; BAP, Benzo[a]pyrene; bHLH-PAS, Basic helix-loop-helix Per-ARNT-Sim; BNF, $\beta$ naphthoflavone; CAR, Constitutive androstane receptor; CFTR, Cystic fibrosis transmembrane conductance regulator; COX, Cyclooxygenase; CYP, Cytochrome P450; DDT, Dichloro-diphenyl-trichloroethane; DLC, Dioxin-like compound; DO, Dissolved oxygen; ECOTOX, Environmental Protection Agency's database of aquatic toxicity testing; ENU, $N$-ethyl- $N$-nitrosourea; ER, Estrogen receptor; ERR, Estrogen receptor-related receptor; EST, Expressed sequence tag; FGC, Fundulus Genomics Consortium; FXR, Farnesoid X-receptor; GO, Gene Ontologies; GR, Glutocorticoid receptor; GST, Glutathione $S$-transferase; HAH, Halogenated aromatic hydrocarbon; HIF, Hypoxia-inducible factor; KEGG, Kyoto Encyclopedia of Genes and Genomes; LDH, Lactate dehydrogenase; LXR, Liver X-receptor; MH, Major histocompatibility; MIS, Maturation induction steroid; MR, Mineralocorticoid receptor; NBH, New Bedford Harbor; NCBI, National Center for Biotechnology Information; $\mathrm{NR}, \mathrm{Nuclear}$ receptor; $\mathrm{NKCC} \mathrm{Na}^{+}, \mathrm{K}^{+}, 2 \mathrm{Cl}^{-}$ cotransporter; NHE, $\mathrm{Na}^{+}-\mathrm{H}^{+}$-exchangers; P450arom, Cytochrome $P 450$ aromatase; PAH, Polycyclic aromatic hydrocarbon; PCB, Polychlorinated biphenyl; $P_{\text {crit }}$, critical oxygen pressure; $\mathrm{PO}_{2}$, Oxygen partial pressure; PCR, Polymerase chain reaction; PXR, Pregnane X-receptor; SET protein, Phosphatase 2A inhibitor I2PP2A; SNP, Single nucleotide polymorphism; TCDD, 2,3,7,8-tetrachlorodibenzo- $p$-dioxin; VDR, Vitamin D receptor.

* Corresponding author. Tel.: +1 843762 8933; fax: +1 8437628737.

E-mail address: burnettk@cofc.edu (K.G. Burnett).
} 


\begin{abstract}
A strong foundation of basic and applied research documents that the estuarine fish Fundulus heteroclitus and related species are unique laboratory and field models for understanding how individuals and populations interact with their environment. In this paper we summarize an extensive body of work examining the adaptive responses of Fundulus species to environmental conditions, and describe how this research has contributed importantly to our understanding of physiology, gene regulation, toxicology, and ecological and evolutionary genetics of teleosts and other vertebrates. These explorations have reached a critical juncture at which advancement is hindered by the lack of genomic resources for these species. We suggest that a more complete genomics toolbox for F. heteroclitus and related species will permit researchers to exploit the power of this model organism to rapidly advance our understanding of fundamental biological and pathological mechanisms among vertebrates, as well as ecological strategies and evolutionary processes common to all living organisms.
\end{abstract}

(C) 2007 Elsevier Inc. All rights reserved.

Keywords: Fundulus heteroclitus; Physiological genomics; Ecological genomics; Evolutionary genomics; Toxicogenomics; Environmental genomics

\title{
Contents
}

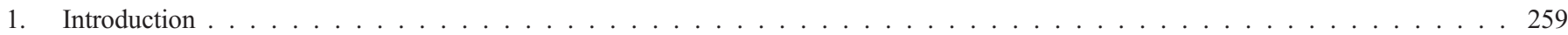

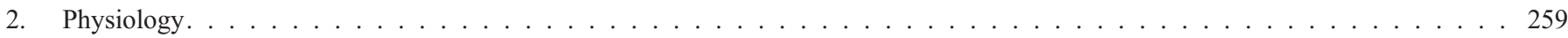

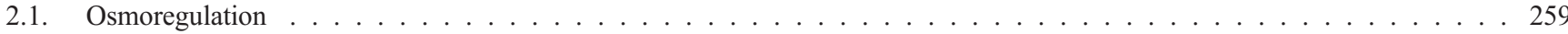

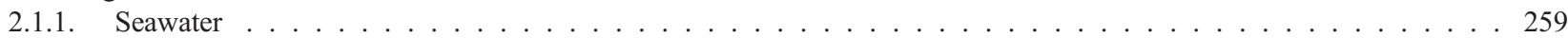

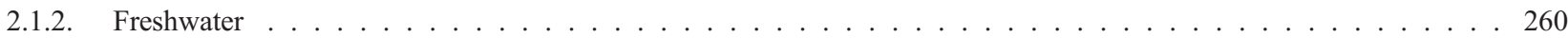

2.1.3. Kidney and intestine . . . . . . . . . . . . . . . . . . . . . . 260

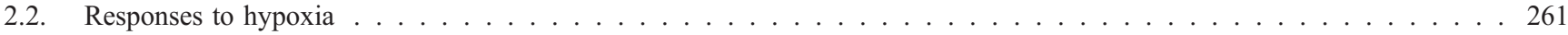

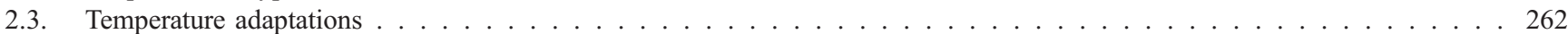

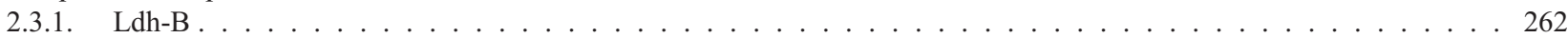

2.3.2. Glycolysis. . . . . . . . . . . . . . . . . . . . . . . . 262

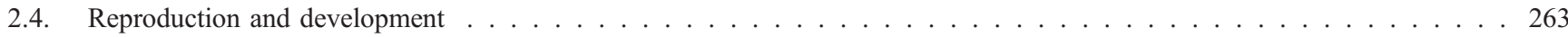

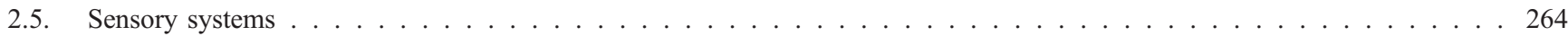

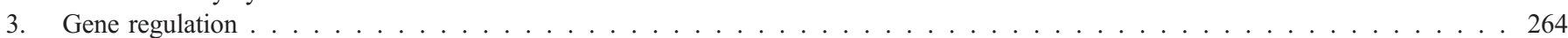

3.1. Receptors and other ligand-activated transcription factors . . . . . . . . . . . . . . . . . . . 265

3.1.1. Nuclear receptors . . . . . . . . . . . . . . . . . . . . . . . . . . 265

3.1.2. Basic helix-loop-helix Per-Arnt-Sim family of proteins . . . . . . . . . . . . . . . . 265

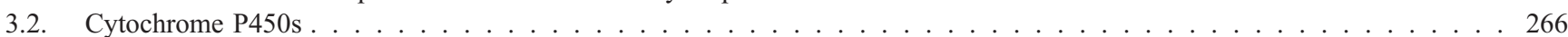

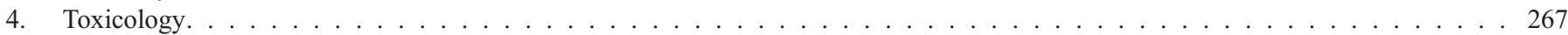

4.1. Reproductive and developmental effects . . . . . . . . . . . . . . . . . . . . . . 267

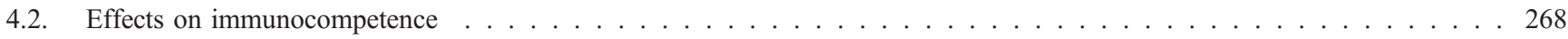

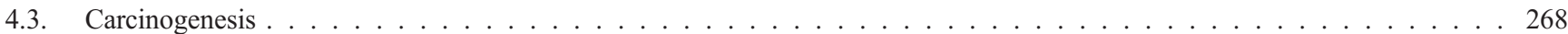

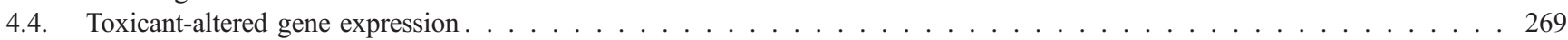

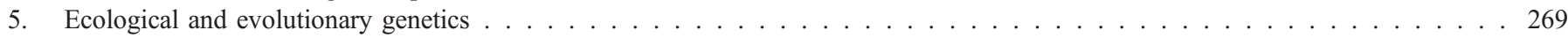

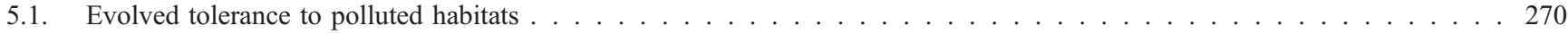

5.1.1. Tolerance to mercury and TCDD (Newark, NJ, USA) . . . . . . . . . . . . . . . . . . . . 270

5.1.2. Tolerance to PCBs (New Bedford Harbor, MA, USA) . . . . . . . . . . . . . . . . . . . . . 270

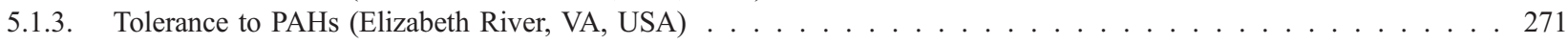

5.2. Evolution of host-parasite interactions . . . . . . . . . . . . . . . . . . . . . . 272

5.3. Evolutionary variation in glycolytic enzyme expression . . . . . . . . . . . . . . . . . . . . . 272

5.4. Evolutionary variation in messenger RNA expression . . . . . . . . . . . . . . . . . . . . . . . . . 273

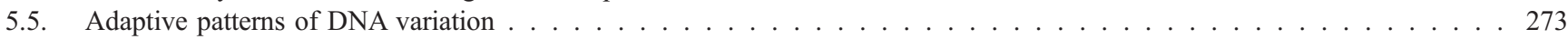

6. Fundulus genomics: current status . . . . . . . . . . . . . . . . . . . . . . . . . 274

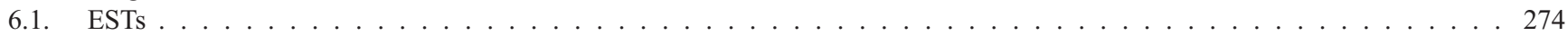

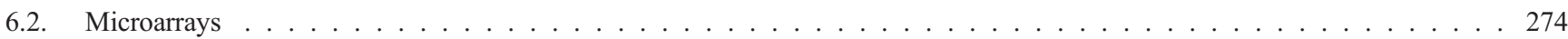

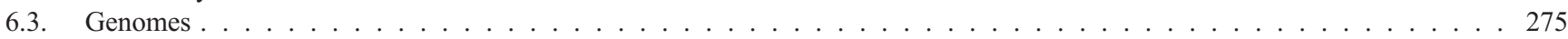

6.4. Natural and constructed genetic modifications . . . . . . . . . . . . . . . . . . . . . 276

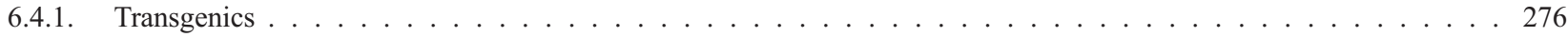

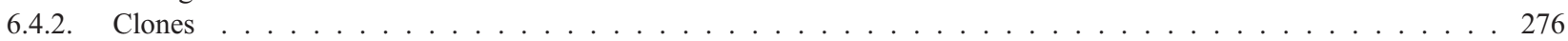

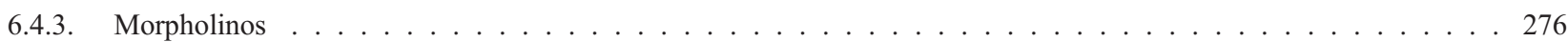

6.4.4. Targeted mutagenesis: knockout mutants . . . . . . . . . . . . . . . . . . . 276

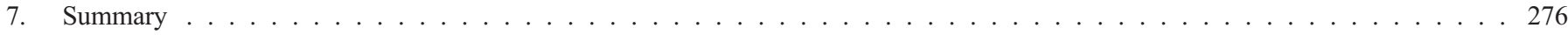

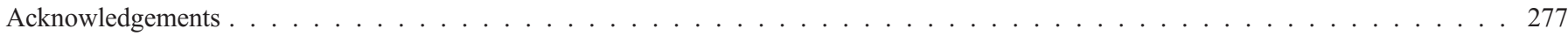

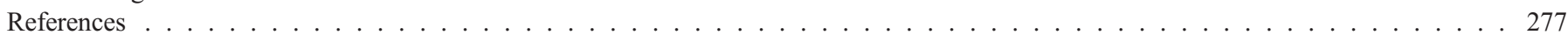




\section{Introduction}

Fundulus is a diverse and widespread genus of small teleost fishes, with species inhabiting coastal marshes from New Brunswick and the north shore of the St. Lawrence to Florida and the Gulf Coast from Florida to Texas, as well as inland systems of North America (Bigelow and Schroeder, 1953; Lee et al., 1980; Scott and Crossman, 1998). Fundulus heteroclitus, also called the killifish, mud minnow or mummichog, is one of the most abundant intertidal marsh fishes along the east coast of North America, where they play a dominant role as both piscivore and prey for a variety of birds, fishes and invertebrates (reviewed in Able, 2002; Able et al., 2007; Kimball and Able, 2007).

F. heteroclitus is non-migratory (Skinner et al., 2005), with local sub-populations exhibiting summer home ranges on the order of 30-40 m (Lotrich, 1975) and greatly restricted winter movements (Fritz et al., 1975). This broad distribution and limited home range have made $F$. heteroclitus a powerful field model for examining biological and ecological responses to natural environmental changes, such as the wide variations in salinity, oxygen, $\mathrm{pH}$, and temperature, that routinely occur in estuarine ecosystems. F. heteroclitus thrive in highly populated coastal areas and chemically-polluted sites where they have evolved mechanisms to tolerate some toxic chemicals. Abundance and accessibility make $F$. heteroclitus easy to collect; their small size and adaptability to a range of environmental conditions make them easy to maintain in the laboratory. All life stages are hardy and amenable to experimental manipulation. These attributes make $F$. heteroclitus a valuable laboratory model for the study of physiological processes such as osmoregulation and reproduction in aquatic vertebrates. Consequently, these organisms are used both in laboratory and field studies to examine basic disease processes and toxicological mechanisms, as well as ecological responses associated with chemical pollutants and other anthropogenic stressors. Finally, the many related species of Fundulus distributed over great geographic distances provide a powerful framework for investigating fundamental ecological and evolutionary processes.

This paper reviews selected key advances in physiology, gene regulation, toxicology, and evolutionary genetics that have relied on the distinctive, often unique, attributes of Fundulidae. Given the scope of research that relies on Fundulus models, this review is not comprehensive; rather, emphasis is placed on research in which genomics-based technologies have enhanced our knowledge of fundamental biological processes. Within this perspective, we summarize genomics resources that are currently available for $F$. heteroclitus. Finally, we argue that further development of such resources will position $F$. heteroclitus and related species as a powerful model system for testing hypotheses regarding biological responses to environmental change across levels of biological organization from molecules to ecosystems.

\section{Physiology}

Physiological studies in F. heteroclitus have been aided by the species tolerance to a range of abiotic factors, ease of capture, and adaptation to laboratory conditions. As described here, research on $F$. heteroclitus has significantly increased our fundamental knowledge on the mechanisms by which fish adapt to key environmental challenges such as changes in salinity (2.1), oxygen levels (2.2) and temperature (2.3). In addition, they have been used to better understand selected integrated systems, such as reproduction and development (2.4) and vision (2.5), among other physiological processes. Many of these studies have led to important new knowledge regarding gene regulation (3.0) and responses to toxicants (4.0).

\subsection{Osmoregulation}

F. heteroclitus is renowned for its euryhaline capabilities, readily adapting to environments ranging from ion-poor to hypersaline conditions as high as $120 \%$ (Griffith, 1974). Based upon this attribute, $F$. heteroclitus has been and continues to be an important model organism for understanding mechanisms of teleost osmoregulation, as documented in two major reviews: Karnaky (1986) focused on chloride cell structure and function and Wood and Marshall (1994) compared in vitro and in vivo approaches to understanding euryhalinity in this species. Current models for teleost ion transport and acid-base regulation in gills (Evans et al., 2004, 2005) and other major osmoregulatory organs (Marshall and Grosell, 2005) also rely extensively on research conducted with $F$. heteroclitus.

\subsubsection{Seawater}

Keys and Willmer (1932) identified a morphologicallydistinct cell type in eel gills that was rich in mitochondria that they reasoned was responsible for $\mathrm{NaCl}$ secretion by marine teleost gills. Philpott and Copeland (1963) recognized a field of these cells in the gills, skin and buccal epithelium of $F$. heteroclitus and described the curious ultrastructure, with a hugely expanded basolateral membrane surface in serpentine tubules that formed a mesh among the well-organized mitochondria. $\mathrm{Na}^{+}, \mathrm{K}^{+}$-ATPase, localized specifically on the basolateral membrane of these "chloride cells" (Karnaky et al., 1976), displayed higher activity in the gills of $F$. heteroclitus adapted to seawater than to fresh water, and higher in both conditions than in fish adapted to brackish water resembling the ionic composition of the blood (Epstein et al., 1967; Towle et al., 1977). These observations of $\mathrm{Na}^{+}, \mathrm{K}^{+}$-ATPase activity explained the transepithelial secretion of $\mathrm{Na}^{+}$, but not $\mathrm{Cl}^{-}$exit from the animal into seawater (Silva et al., 1977).

An explanation for the movement of $\mathrm{Cl}^{-}$against both electrical and concentration gradients, the "pump-leak" pathway, relied on two additional discoveries: a transporter that used the $\mathrm{Na}^{+}$gradient to drive $\mathrm{Cl}^{-}$accumulation intracellularly and an anion channel in the apical membrane that allowed the $\mathrm{Cl}^{-}$to leak out into the environment. Using the patch-clamp technique, Marshall et al. (1993) showed that the F. heteroclitus chloride cell has a channel that is similar to the mammalian cystic fibrosis transmembrane conductance regulator (CFTR). Singer et al. (1998) cloned this CFTR homolog in F. heteroclitus, showing that its expression increased after transfer to seawater, and that cAMP activated anion conductance by the channel 
when expressed in amphibian oocytes. Adaptation to seawater augments ion secretion in parallel with CFTR expression (Marshall et al., 1999) and there is mobilization of both the CFTR and $\mathrm{Na}^{+}, \mathrm{K}^{+}, 2 \mathrm{Cl}^{-}$cotransporter (NKCC) in chloride cells, placing more of the former in apical membrane and more of the latter in the basolateral membrane (Marshall et al., 2002).

Soon after Eveloff et al. (1978) first recognized the role of NKCC in ion balance in the shark rectal gland, Degnan et al. (1977) documented NKCC function in isolated opercular membranes of $F$. heteroclitus. Since then, others have shown NKCC dependence on $\mathrm{K}^{+}$(Marshall, 2002), inhibition by loop diuretics (Eriksson et al., 1985; Marshall and Grosell, 2005), and expression changes during adaptation to seawater (Scott et al., 2004a). Other recent studies in this area have explored the regulatory pathways involved in NKCC activation (Flemmer et al., 2002; Gagnon et al., 2006) and the role of inducible cyclooxygenase COX-2 in seawater acclimation (Choe et al., 2006; Delpire and Gagnon, 2006). COX-2 regulates prostaglandin metabolism and mediates eicosanoid synthesis which, in turn, regulate $\mathrm{NaCl}$ secretion by the killifish opercular epithelium (Van Praag et al., 1987; Evans et al., 2004).

The $\mathrm{Na}^{+}, \mathrm{K}^{+}$-ATPase, which is responsible for producing the $\mathrm{Na}^{+}$transmembrane gradient that drives NKCC operation, has been cloned from $F$. heteroclitus (Semple et al., 2002). Current evidence indicates a complicated layering of regulation at the protein and expression levels associated with adaptation to seawater (Mancera and McCormick, 2000; Lima and Kültz, 2004; Scott et al., 2004a,b; Choe et al., 2006). The $\mathrm{Na}^{+}-\mathrm{H}^{+}-$ exchangers (NHE), which are usually associated with acid secretion in freshwater ion and acid-base balance (Evans et al., 2005), also appear to play a role in the regulation of acid transport in marine conditions (Edwards et al., 2005).

\subsubsection{Freshwater}

Most of the osmoregulatory research with $F$. heteroclitus has been directed toward mechanisms accommodating increased salinities, yet the converse, adjustment to lower salinities, requires even more challenging and diverse strategies (Evans et al., 2005; Marshall and Grosell, 2005). Because freshwater habitats are geologically transient, with inland lakes and streams forming with geological changes, there have been innumerable opportunities for different freshwater osmoregulatory mechanisms to evolve. As a result, the paradigm followed by the major model species, e.g. rainbow trout, in which acid-secreting and base-secreting cells operate in parallel to link acid-base regulation with $\mathrm{NaCl}$ uptake (Evans et al., 2005), is not present in other groups. F. heteroclitus (Katoh et al., 2003) expresses the pivotal enzyme V-type $\mathrm{H}^{+}$-ATPase in the basolateral rather than the apical membrane, as in trout (Lin et al., 1994). The seawater opercular membrane secretes $\mathrm{NaCl}$, as does the gill. However, in freshwater the gills actively absorb $\mathrm{Na}^{+}$but not $\mathrm{Cl}^{-}$ (Wood and Marshall, 1994), while the opercular epithelium actively absorbs $\mathrm{Ca}^{2+}$ (Patrick et al., 1997; Patrick and Wood, 1999; Marshall and Grosell, 2005) and $\mathrm{Cl}^{-}$(Marshall et al., 1997), but not $\mathrm{Na}^{+}$. Adaptation to freshwater relies on complex dynamics of $\mathrm{Na}^{+}-\mathrm{H}^{+}$-exchanger isoforms, $\mathrm{Na}^{+}, \mathrm{K}^{+}$-ATPase and carbonic anhydrase (Edwards et al., 2002, 2005; Scott et al., 2005a) and likely reflects both a rapid turnover of transporting cells (Daborn et al., 2001; Laurent et al., 2006) and a $\mathrm{Na}^{+}$uptake system that could rely instead on $\mathrm{Na}^{+}-\mathrm{H}^{+}$-exchange or neutral $\mathrm{NaCl}$ cotransport. As a result, $\mathrm{Na}^{+}$uptake is much less efficient than in the trout, yet it is a mechanism that still operates sufficiently to allow $F$. heteroclitus to occupy even ion-poor freshwater habitats, so long as the animals are actively feeding. Indeed the ionic contribution of food is essential for $F$. heteroclitus survival in ion-poor freshwater because $\mathrm{Cl}^{-}$uptake is limited in the opercular membrane and absent in the gill (Marshall et al., 1997; Laurent et al., 2006).

Although the important discovery of CFTR occurred in $F$. heteroclitus before other teleosts, and other transport protein genes are now known $\left(\mathrm{Na}^{+}, \mathrm{K}^{+}\right.$-ATPase, NHE, carbonic anhydrase, $\mathrm{H}^{+}$-ATPase, NKCC), many other transporter homo$\operatorname{logs}$ and their regulatory proteins remain enigmatic. Importantly, the regulatory proteins that may be intimately associated with $\mathrm{Na}^{+}, \mathrm{K}^{+}$-ATPase, $\mathrm{H}^{+}$-ATPase, NKCC, and CFTR are not yet described. To date only three potential regulatory proteins have been sequenced, the glucocorticoid receptor (Scott et al., 2005a), COX-2 and the 14-3-3 protein (Kültz et al., 2001; Scott et al., 2004a, 2005a; Choe et al., 2006).

\subsubsection{Kidney and intestine}

In the marine environment $F$. heteroclitus (Malvin et al., 1980; Burgess et al., 1998) drinks to offset osmotic water loss to the environment in a reflex stimulated by angiotensins. The intestine absorbs water and ions from the seawater ingested by the animal and in the posterior portion there is also some ion secretion, specifically of bicarbonate (Marshall and Grosell, 2005). The digestive tract of $F$. heteroclitus is unusual as it lacks a stomach and is relatively short. The intestine is normally absorptive, involving $\mathrm{NaCl}$ absorption in parallel to water channels that impart hydraulic conductivity and allow fluid reabsorption. The kidney of teleosts is an important means for excretion of water by freshwater-adapted teleosts and in marine teleosts for the secretion of divalent ions, especially $\mathrm{Mg}^{2+}, \mathrm{Ca}^{2+}$ and $\mathrm{SO}_{4}^{2-}$ (Marshall and Grosell, 2005). The $F$. heteroclitus kidney is small and has a reduced urinary bladder where ureteral urine might accumulate and be altered before release. In seawater, tubular secretion of $\mathrm{Na}^{+}$and $\mathrm{Cl}^{-}$occurs as secondary active $\mathrm{Cl}^{-}$transport with electrically coupled paracellular $\mathrm{Na}^{+}$transport. Electrochemical gradients for $\mathrm{K}^{+}$ and $\mathrm{Na}^{+}$allow $\mathrm{Cl}^{-}$entry across the basolateral membrane presumably via $\mathrm{NKCC}$ and results in cytosolic $\mathrm{Cl}^{-}$concentrations above electrochemical equilibrium. Apical $\mathrm{Cl}^{-}$secretion is via a cAMP stimulated conductive pathway, by an as yet unidentified anion channel (Cliff and Beyenbach, 1992; Marshall and Grosell, 2005). In both seawater and freshwater killifish, NKCC immunoreactivity was detected in the apical membrane of the distal and collecting tubules, and in the basolateral membrane of the second segment of the proximal tubules, the major part of killifish renal tubules (Katoh, F., Cozzi, R.R.F., Marshall, W.S., and Goss, G.G., unpublished data). These results support the secretory function of the early and absorptive function of the more distal portions of renal tubules of these euryhaline fishes. 
In freshwater, the killifish proximal tubule is also secretory (Cliff and Beyenbach, 1992), being balanced by reabsorptive $\mathrm{NaCl}$ transport in the distal portions of the tubule for the net excretion of dilute urine. As mentioned above, NKCC in freshwater killifish kidney have the same immunolocalization as the kidney of seawater individuals, and agreeing with the functional findings by Cliff and Beyenbach (1992). Development of miniaturized techniques and molecular approaches that use small tissue samples will enable future studies of transporter and channel expression in the kidney, a wide-open and particularly fascinating area for study.

\subsection{Responses to hypoxia}

The responses of $F$. heteroclitus to changes in oxygen have received considerable attention because this species and related Fundulidae thrive in estuarine habitats with variable and frequently low oxygen concentrations (Diaz and Rosenberg, 1995; Diaz, 2001; Smith and Able, 2003) and because hypoxia has been shown to cause reproductive and developmental effects in several species of fishes (Wu et al., 2003; Shang and Wu, 2004; Shang et al., 2006). In comparison to other abundant resident and transient marsh fishes, F. heteroclitus was found to be most tolerant of low oxygen (Davanzo and Kremer, 1994; Wannamaker and Rice, 2000; Smith and Able, 2003), with little or no mortality occurring until dissolved oxygen drops below $1 \mathrm{mg} \mathrm{L}^{-1}$ [DO of $1 \mathrm{mg} \mathrm{L}^{-1}$ is equivalent to an oxygen partial pressure $\left(\mathrm{PO}_{2}\right)$ of $2.9 \mathrm{kPa}$ at $25^{\circ} \mathrm{C}$ and $25-30 \mathrm{ppt}$ salinity] (Voyer and Hennekey, 1972; Smith and Able, 2003). Consistent with this high tolerance of hypoxia, $F$. heteroclitus does not avoid water of $1 \mathrm{mg} \mathrm{L}^{-1}$ in laboratory choice experiments, whereas other marsh fish show strong avoidance behaviors (Wannamaker and Rice, 2000). Fundulus grandis occurs in similar habitats along the Gulf of Mexico (Timmerman and Chapman, 2004), and has a correspondingly high hypoxia tolerance (Rees et al., 2001; Love and Rees, 2002). Thus, studies of the physiological and molecular mechanisms that underlie this tolerance to hypoxia in Fundulus species offer unique insights into individual and population level adaptations to low oxygen.

Like most fish, $F$. heteroclitus and $F$. grandis are oxygen regulators: aerobic metabolism is independent of water $\mathrm{PO}_{2}$ across a broad range, but becomes limited at low $\mathrm{PO}_{2}$. The point at which respiration becomes dependent upon ambient oxygen, the critical oxygen pressure $\left(P_{\text {crit }}\right)$, is about $4.6 \mathrm{kPa}$ (DO of $1.6 \mathrm{mg} \mathrm{O}_{2} \mathrm{~L}^{-1}$ ) in both species (Cochran and Burnett, 1996; Virani and Rees, 2000). During chronic exposure to oxygen tensions near their $P_{\text {crit, }}$, the oxygen-binding capacity of blood in $F$. heteroclitus increases due to increases in hematocrit and hemoglobin oxygen affinity (Greaney and Powers, 1977, 1978; Greaney et al., 1980). The increase in hematocrit is likely due to several factors, including splenic contraction and, potentially, synthesis and maturation of red blood cells stimulated by erythropoietin (Lai et al., 2006). The increase in hemoglobin oxygen affinity is mediated, in part, by a decrease in red blood cell ATP, a negative allosteric regulator of oxygen affinity in fish (Greaney and Powers, 1977, 1978). As oxygen drops below $P_{\text {crit }}, F$. heteroclitus and $F$. grandis recruit anaerobic metabolism to augment energy production. Glycolysis is the primary pathway of anaerobic energy metabolism in fishes, and greater rates are reflected by the accumulation of lactate in blood and tissues. Increased blood and tissue lactate have been documented in Fundulus species after both acute and chronic hypoxic exposure (Greaney and Powers, 1978; Greaney et al., 1980; Cochran and Burnett, 1996), with as much as a 20 -fold increase in blood lactate in $F$. grandis exposed to acute hypoxia $(1 \mathrm{~h}$, $\mathrm{PO}_{2}=1.9 \mathrm{kPa}$ ) (Virani and Rees, 2000). However, even these elevated rates of lactate accumulation only accounted for a fraction $(25-50 \%)$ of decreased ATP yield from reduced aerobic metabolism. This suggests that overall metabolism (ATP turnover) is suppressed in these fish during hypoxic exposure.

Low oxygen negatively impacts growth and reproduction of Fundulus spp. (see also Reproduction and Development, below). Stierhoff et al. (2003) observed lower growth rates in F. heteroclitus over a 9 day exposure to $1.0 \mathrm{mg} \mathrm{L}^{-1}$ compared to normoxic controls, most likely due to decreased food intake during hypoxia. Three other observations of this study are especially noteworthy: first, moderate hypoxia $\left(3.0 \mathrm{mg} \mathrm{L}^{-1}\right)$ did not reduce growth; second, the negative effects of severe hypoxia were partly, but not completely, offset when fish were allowed access to the surface and engaged in aquatic surface respiration; and third, growth was not negatively affected when oxygen concentrations were varied between 1.0 and $11.0 \mathrm{mg}$ $\mathrm{L}^{-1}$ on a diel cycle. This latter treatment, which simulates naturally occurring oxygen cycles, suggests that brief daily exposures to low oxygen are not detrimental to growth as long as fish experience normal oxygen levels for part of the day. In $F$. grandis exposed to chronic hypoxia (28 days at $1.3 \mathrm{mg} \mathrm{L}^{-1}$ ), indices of growth and reproduction (gonad-somatic index, sex hormones, and number of eggs spawned) were lower in fish held under hypoxia compared to normoxic controls (Landry et al., 2007) suggesting a possible link to population effects of chronic hypoxia.

The effects of hypoxia on the expression of specific genes, or, more commonly, the activities of their protein products, have been documented in F. heteroclitus and F. grandis, especially with regard to their capacity for carbohydrate metabolism. Under appropriate conditions, maximal enzyme activity reflects protein amount, and hence serves as a proxy for changes in gene expression (Pierce and Crawford, 1994). Greaney et al. (1980) found significantly higher activities of three enzymes of carbohydrate metabolism in liver, but not in skeletal muscle, of $F$. heteroclitus during chronic hypoxia. Increased activities of many but not all liver glycolytic enzymes have been documented in $F$. heteroclitus and F. grandis following exposure to hypoxia (Kraemer and Schulte, 2004; Martinez et al., 2006). In F. grandis, fewer and smaller changes in the glycolytic enzyme activities were noted in heart and brain while many enzymes were strongly suppressed in skeletal muscle (Martinez et al., 2006). In aggregate, these results demonstrate that chronic hypoxia alters the capacity for carbohydrate metabolism in F. heteroclitus and F. grandis, with the important caveat that the responses are both tissue- and enzyme-specific.

Microarrays have been used to study the effects of hypoxia on global gene expression in two other teleost fish (Gracey 
et al., 2001; Ton et al., 2003; Van der Meer et al., 2005). In all three studies, hypoxia resulted in changes in the levels of numerous transcripts encoding proteins involved carbohydrate metabolism, protein synthesis, cell proliferation, and motility. In contrast, a proteomic study of zebrafish skeletal muscle revealed limited changes in protein expression after hypoxia (Bosworth et al., 2005). The difference between results of microarray and proteomic studies may be due to experimental design (levels and lengths of hypoxia) or biological differences (species, tissues, or developmental stages), or could be the result of uncoupling of mRNA and protein expression under hypoxia.

\subsection{Temperature adaptations}

F. heteroclitus is distributed along one of the largest and steepest thermal cline in the world, the eastern seacoast of North America where there is a $1{ }^{\circ} \mathrm{C}$ change per degree latitude (Powers et al., 1993; Crawford et al., 1999a). Thus, fish in Maine are more than $12{ }^{\circ} \mathrm{C}$ cooler than fish from Georgia. This steep thermal gradient is thought to be responsible for many of the biochemical and physiological differences among populations. For example, there are many enzyme loci where one allelic isozyme replaces another along the coast (Place and Powers, 1978; Powers and Place, 1978; Palumbi et al., 1980; Cashon et al., 1981; Van Beneden and Powers, 1985; Brown et al., 1988; Ropson and Powers, 1989; Ropson et al., 1990). For one of these loci, the heart-type lactate dehydrogenase (Ldh-B), the clinal variation is selectively important (Powers et al., 1991; Crawford et al., 1999a).

\subsection{1. $L d h-B$}

In the teleost fish $F$. heteroclitus, the heart-type lactate dehydrogenase (Ldh-B) encodes two predominant allelic isozymes: $\mathrm{LDH}-\mathrm{Bb}_{4}$ (a homotetramer of one allelic form) in the northern population and $\mathrm{LDH}-\mathrm{Ba}_{4}$ (a homotetramer of an alternative allelic form) in the southern population (Place and Powers, 1978; Powers and Place, 1978). Sequence comparisons (Lauerman, 1990; Bernardi et al., 1993) reveal two nonsynonymous changes which distinguish the two codominant Ldh-B alleles. One of these polymorphisms is located in exon 7 , encoding amino acid position 311 (northern serine, southern alanine). The other polymorphism is located in exon 4, encoding amino acid position 185 (northern alanine and southern asparagine). This 4 th exon amino acid substitution was found to be responsible for the difference in the thermal stability of the two LDH-B allelic enzymes (Lauerman, 1990).

The considerable evolutionary investigations of Ldh-B polymorphisms (see review by Powers et al., 1993) have focused on the apparent adaptive differences between populations in the northern and southern extremes of $F$. heteroclitus' distribution along the North American Atlantic Coast. The variations at the Ldh-B locus reflect this difference in environmental temperature: northern populations produce an enzyme with a lower $K_{\mathrm{m}}$ and greater $k_{\mathrm{cat}}$ when measured at low or intermediate temperatures (Place and Powers, 1979, 1984), and have significantly greater levels of Ldh-B transcription that results in greater concentration of this protein (Crawford and
Powers, 1989, 1992). These differences compensate for the effect of lower habitat temperature on metabolism (Crawford and Powers, 1989) and appear to be an adaptive response to lower temperature (Place and Powers, 1979; Pierce and Crawford, 1997b; Crawford et al., 1999b). The biochemical differences in the Ldh-B enzyme are important for organismal performance. Individuals from a single well-mixed population that are homozygotic for $\mathrm{Ldh}-\mathrm{Bb}_{4}$ (northern alleles) swim faster at the lower temperatures than individuals homozygotic for Ldh$\mathrm{Ba}_{4}$, reflecting the difference in enzyme kinetics (DiMichele and Powers, 1982b). Developmental rates and metabolisms are affected by the Ldh-B genotype (DiMichele and Powers, 1982a, 1984a; Paynter et al., 1991) and juvenile survival is dependent on the Ldh-B genotype (DiMichele and Powers, 1991). Importantly, metabolic rates are directly affected by the Ldh-B genotype. Replacing one allelic form of the protein with another alters the rate of carbon flux (DiMichele et al., 1991).

\subsubsection{Glycolysis}

The Ldh-B locus is an example of biochemical adaptation. To better quantify the frequency of adaptive changes, the variation in enzyme concentration was examined for all the eleven glycolytic enzymes within and among species of Fundulus acclimated to one temperature, including 14 taxa (8 species, with 2 populations from 6 species) of Fundulus (Pierce and Crawford, 1997b; Crawford et al., 1999a). Among these 14 taxa were 3 pairs of sister species where one species was distributed along the steep thermal cline of the North American Atlantic coast and the sister species lacked this distribution (Pierce and Crawford, 1997a). Measuring all eleven glycolytic enzymes among all these taxa allow us to test the effect of phylogeny and whether the changes in enzyme expression were adaptative or more parsimoniously described as neutral evolved changes.

Much of the variation in 7 of the 11 glycolytic enzymes is explained by phylogenetic distance. With greater evolutionary distances, there are greater differences between taxa. Thus these differences are most parsimonously explained by random changes among lineages (Pierce and Crawford, 1997a). The amount of variation that can be explained by phylogenetic distance exceeds $70 \%$ for some enzymes. However, among the glycolytic enzymes within and among Fundulus species, there are significant variations in three enzymes (glyceraldehyde 3phosphate dehydrogenase, pyruvate kinase and $\mathrm{LDH}$ ) that cannot be explained by phylogenetic distance. These three enzymes have a pattern of variation in which species distributed along the steep thermal cline of the North American Atlantic coast have greater intraspecific variation than their sister taxa that exist in the Gulf of Mexico, where no clinal variation in temperature exists. Not only is there a difference in the amount of variation but there is a specific pattern: these three enzymes have greater concentration in taxa subjected to colder environmental temperatures. This trend - more enzyme in colder environments - is significant among Fundulus species after accounting for the phylogenetic relationships. It is very unlikely that random or neutral evolutionary processes could create this pattern of variation among all the species and 
populations tested. The most likely, and the most parsimonious, explanation for the variation in these three enzymes is that they have evolved by natural selection.

Metabolism is most likely to be affected by the changes in glycolytic enzyme expression. To test this, Podrabsky et al. (2000) examined the variation in cardiac glucose use in southern and northern population of $F$. heteroclitus. At a single common temperature heart ventricles from northern $F$. heteroclitus utilized glucose faster than hearts from southern fish. After measuring all eleven glycolytic enzymes in these individuals, the variation in enzyme concentration of three enzymes explained most the variation in glucose utilization: glyceraldehyde 3phosphate dehydrogenase, pyruvate kinase and LDH. These are the same loci where the variation in concentration was identified as evolutionarily important by Pierce and Crawford (1997a). These data indicate that the adaptive variation in enzyme expression affected cardiac metabolism.

These data on Ldh-B and on the glycolytic enzymes provide some of the most extensive data on biochemical adaptation to temperature. This research was made possible by the uniquely broad population and phylogenetic variation within and among Fundulus species.

\subsection{Reproduction and development}

The reproductive strategy of killifish demonstrates several adaptations that maximize reproductive success in the intertidal zone generally and, more specifically, at local residence sites. Adult killifish often display semi-lunar reproductive (including endocrine) cycles, coincident with spring tide cycles, which synchronizes reproductive maturity and spawning with availability of specific spawning substrates that are restricted to spring tides (Taylor, 1986). F. heteroclitus typically deposit eggs at the high water mark during high spring tides associated with new and full moons (Hsiao et al., 1996; Taylor, 1999). Therefore, mature gametes are usually produced within 5 days of a spring tide. The maturation of eggs from vitellogenic follicles is associated with the accumulation of vitellogenin, a yolk precursor protein (Selman and Wallace, 1983, 1986). The accumulation of vitellogenin appears to be triggered by increased levels of estrogen in the bloodstream, leading to the hepatic induction of the estrogen-responsive vitellogenin gene (Cerda et al., 1996; Hsiao et al., 1996). These vitellogenic follicles progress from early-maturing follicles and then to latematuring follicles in response to a maturation induction steroid (MIS), 17 $\alpha, 20 \beta$-dihydroxy-4-pregnen-3-one (Greeley et al., 1986; Petrino et al., 1993; Cerda et al., 1996; Hsiao et al., 1996). While the exact trigger for ovulation in killifish is unknown, it is thought that increases in serum levels of estradiol-17 $\beta$ play a role because of an increased production of estradiol-17 $\beta$ by mature follicles (Bradford and Taylor, 1987; Lin et al., 1987; Petrino et al., 1989, 1993; Hsiao et al., 1996).

Eggs are laid in multiple clutches in groups of 50 to several hundred depending on the spawning substrate (Taylor, 1999). Like many other Cyprinodontiform fish, $F$. heteroclitus are oviparous with external fertilization (Meyer and Lydeard, 1993). Killifish eggs are resistant to desiccation, an adaptation that permits them to be laid at the high water mark. While it has been reported that eggs can survive aerially for 14 days or more, a recent study has shown that this dessication resistance is only effective over short time periods of $2 \mathrm{~h}$ or less in relative humidities of $84 \%$ or less. Nonetheless, long-term egg survival may be possible depending on the humidity of the microenvironment where eggs are laid (Preston et al., 2006). In nature, eggs hatch upon immersion in water. Nonetheless, field experiments showed that eggs exposed to continuous immersion or daily immersion by flood tides failed to develop, while those placed at the high tide mark developed and hatched within 14 days as the high tide reached them (Taylor and DiMichele, 1983).

Killifish eggs are adapted to hatch only upon immersion in water and embryo development takes only 9-15 days, therefore, eggs laid on one high tide are ready to hatch with the next tide (Taylor, 1999). Like other teleosts, egg hatching is triggered by the release of chorionase, an enzyme found in hatching gland cells. These cells are located in the buccal cavity of the opercular epithelium, and are fully developed by approximately 9 to 10 days (Armstrong and Child, 1965; Taylor, 1999). Immediately after hatching, $F$. heteroclitus are free-swimming larvae.

There is some variation in developmental and hatching rates depending on dissolved oxygen levels, temperature, photoperiod, and latitude (DiMichele and Powers, 1984b; DiMichele and Westerman, 1997; Shimizu, 2003). For example, northern populations from Massachusetts and Delaware had median hatching times between 10.5 and 12.5 days, while a southern population of killifish from Georgia exhibited hatching times of 14-15 days (DiMichele and Westerman, 1997). However, it appears that these observed differences in hatching time due to latitude counterbalance the effect of water temperature differences across the geographic distribution of the species. DiMichele and Westerman (1997) reported that among killifish collected from Massachusetts, Delaware, and Florida at temperatures between 15 and $30{ }^{\circ} \mathrm{C}$, those from Massachusetts reached hatching stage faster than the other populations. Additionally, eggs from Massachusetts failed to survive at $30{ }^{\circ} \mathrm{C}$, while those from Florida failed to survive at $15^{\circ} \mathrm{C}$. Thus, each population is adapted to local thermal conditions such that hatching occurs within 10-15 days. Other factors such as metabolic rate (Paynter et al., 1991), enzyme activity (DiMichele and Powers, 1991), or hemoglobin function (Powers et al., 1979) may also result in hatching time variation (Taylor, 1999). However, population-specific adaptations have likely arisen due to the small home ranges of these non-migratory fish, thus allowing for the development over multiple generations of reproductive adaptations to the temperature and climate of their immediate environment (Lotrich, 1975).

Many of the same adaptations that are useful for reproductive success in intertidal environments also make $F$. heteroclitus well-suited to laboratory experimentation. The semi-lunar spawning cycle continues to occur without lunar or tidal stimuli (Taylor, 1986). Thus, F. heteroclitus spawning cycles can be maintained in captivity and are free-running in the laboratory (Taylor, 1986; Hsiao and Meier, 1992; Hsiao et al., 1994, 1996). However, laboratory cycling causes individuals to lose their 
synchrony, both to high tide and lunar patterns, as there is no entrainment (Taylor, 1991). Nonetheless, a free-running reproductive cycle is advantageous as it allows for daily egg collection and frequent ovarian sampling (Hsiao et al., 1996). Predictable spawning in the field and under lab conditions provides a ready source of embryos. Females produce dozens of eggs for each of many semi-lunar cycles over several months in the field or in the laboratory with high rates of embryonic and early larval survival (Taylor et al., 1979; Hsiao et al., 1996; Black et al., 1998a; Nacci et al., 1998, 2005).

Reproduction and development in F. heteroclitus display several other features that continue to make the species an important model for basic and applied research. Killifish produce large (approximately $2.0 \mathrm{~mm}$ diameter), robust eggs that readily lend themselves to embryological and developmental studies (Trinkaus, 1963; Armstrong and Child, 1965; Atz, 1986; Weis and Weis, 1989; Trinkaus, 1998; Taylor, 1999). Eggs can be stripped from females and fertilized in vitro (Armstrong and Child, 1965). While these features are not different from zebrafish (Danio rerio), embryonic development in killifish is much more protracted ( 9 days versus 3 days in zebrafish), which facilitates observation and experimental intervention. These attributes have also made the embryonic development of varying populations of $F$. heteroclitus important test subjects for toxicological investigations (see below, Toxicology). A final advantage of killifish for reproductive, developmental, and genetic studies rests on the fact that female hybrids of $F$. heteroclitus and $F$. diaphanous reproduce clonally. This feature has not been exploited to date but could be valuable in the future for studies requiring non-recombinant genetic conditions and may also increase understanding of clonal reproduction in vertebrates (Dawley, 1992).

\subsection{Sensory systems}

In the estuarine environment $F$. heteroclitus is both an active predator and an important prey item. It is expected that a welldeveloped sensory system would be an asset to these active fish. Surprisingly, research on the sensory systems of $F$. heteroclitus has been essentially limited to its visual system. That $F$. heteroclitus are visual fish is suggested by the enhanced overall coloration of the males during spawning season. There are even suggestions that killifish possess the ability to change color in response to background color. In addition, the eye and its many complex components, such as the retina, have been the source of discovery of unique gene isoforms, including a $F$. heteroclitus retinal specific lactate dehydrogenase-C (Ldh-C) isoform (Quattro et al., 1993).

The osmoregulatory mechanisms described for the gill and opercular epithelium (see above, Osmoregulation) provide the basis for characterizing the unique mechanisms required to maintain hydration levels in the eye. In particular, the lens epithelial layer is important in maintaining tightly regulated internal ion and hydration balance in the avascular lens (for review see Delamere and Tamiya, 2004). Preliminary studies suggest that killifish lenses undergo reversible changes in opacity during seawater adaptation (Dixon, M. and Singer, T.D., unpublished data). Likewise, abrupt changes in salinity have been associated with lens opacities and cataract formation in salmonid fish species during smoltification (Bjerkas et al., 2003). Because compromised transporter function in mammalian lens has been associated with cataract formation (Moseley et al., 2002), mechanisms used by $F$. heteroclitus to maintain lens clarity during salinity change may permit greater understanding of cataract formation.

The killifish has a wide latitudinal distribution that gives rise to both thermal and lighting gradients. Temperature plays an important role in determining the retinal rod outer segment length in F. zebrinus (Allen, 1995). In the bluefin killifish, $\mathrm{Lu}$ cania goodie, the expression patterns of retinal UV and other photo pigments were correlated with gradients in the lighting environment (Fuller et al., 2004, 2005). Natural populations of F. heteroclitus are distributed over a wide, well-studied thermal gradient (for example, Fangue et al., 2006); light intensities are expected to vary even more dramatically along the same gradient. Thus $F$. heteroclitus is an important model to investigate the evolution of vision in a biophysically-variable environment.

Several other specific visual system components have been characterized in the killifish. F. heteroclitus possesses four cone types including UV cones (Flamarique and Harosi, 2000). The presence of UV cones, although rare among marine teleosts, is similar to teleost fishes including cyprinids and salmonids, and may be important in increasing prey contrast as well as in conspecific communication. Additional studies have described the ultrastructure of the pineal organ of the F. heteroclitus and compared its dual role as a photosensor and secretory organ (Omura and Ali, 1981).

Clearly Fundulus species provide an unparalleled model in which to examine basic physiological processes and adaptations to environmental change. Limited genomic and proteomic efforts have been begun to examine reproduction and development, and sensory systems, as well as the adaptations to changes in salinity and oxygen pressure. Greater access to genomic resources for $F$. heteroclitus would provide the opportunity to examine the potential involvement of broad suites of genes and proteins in physiological processes, both hastening and deepening our understanding of functional plasticity among vertebrates. Many of these resources can be made readily available to physiologists because of the extensive work that has been done by others in Fundulus genomics, as noted in the following sections.

\section{Gene regulation}

The extensive body of work examining the responses of $F$. heteroclitus to environmental perturbations has contributed enormously to our understanding of basic processes of cell signaling and gene expression, including the induction of biotransformation enzymes, anti-oxidant enzymes and transporters. Many of the most prominent environmental contaminants and other physiological stressors cause changes in gene expression through activation of receptors or other ligandactivated transcription factors. Several environmentally-relevant 
transcription factors have been characterized in species of Fundulus, in some cases confirming findings in other fish and in other cases providing novel insight into receptor diversity. Key examples are summarized here.

\subsection{Receptors and other ligand-activated transcription factors}

\subsubsection{Nuclear receptors}

Members of the nuclear receptor superfamily have important roles in endocrinology and, as such, have emerged as targets or potential targets of endocrine-disrupting environmental chemicals. Among these, the estrogen receptors (ERs; NR3A subfamily) have received the most attention. F. heteroclitus, like other fishes, differs from mammals in having two ER $\beta$ paralogs (ER $\beta a$ and $E R \beta b)$ in addition to a single ER $\alpha$ (Urushitani et al., 2003; Greytak and Callard, 2007). Evidence that these ERs are involved in toxic and adaptive responses to contaminant exposure is discussed below (Toxicology). In addition to the ERs, $F$. heteroclitus have four ER-related receptors (ERRs; NR3B) (Tarrant et al., 2006). Although not well understood even in mammals, these enigmatic members of the nuclear receptor family are potential targets for xenoestrogens (Coward et al., 2001; Tremblay et al., 2001). cDNA fragments of glucocorticoid and mineralocorticoid receptors (GR and MR; NR3C), which are involved in stress response and osmoregulation and also are potential targets for environmental chemicals, have been identified in F. heteroclitus, (Coward et al., 2001; Scott et al., 2004a; Marshall et al., 2005; Scott et al., $2005 b)$. One group of nuclear receptors that has not yet been well-characterized in $F$. heteroclitus includes families NR1H and NR1I, which contain constitutive androstane receptor (CAR), pregnane X-receptor (PXR), vitamin D receptor (VDR), liver X-receptor (LXR), and farnesoid X-receptor (FXR). These receptors have important roles in the regulation of biotransformation enzymes, transferases, and transporters in response to endogenous toxicants such as bile acids and heme breakdown products (bilirubin) as well as to xenobiotics. Studies in other fish suggest that killifish possess a PXR, LXR, and FXR, but not CAR (Moore et al., 2002; Maglich et al., 2003). F. heteroclitus PXR and FXR orthologs have recently been cloned (S.I. Karchner and M.E. Hahn, unpublished data).

\subsubsection{Basic helix-loop-helix Per-Arnt-Sim family of proteins}

Members of the bHLH-PAS family of transcription factors are involved in developmental signaling and in sensing environmental variables such as light, oxygen, and chemicals. The most well known chemical sensor in this family is the aryl hydrocarbon receptor (AHR), which in mammals exists as a single gene. The AHR regulates the expression of cytochrome P450s (CYPs) and other genes in response to planar halogenated aromatic hydrocarbons $(\mathrm{HAH})$ such as 2,3,7,8tetrachlorodibenzo- $p$-dioxin (TCDD) and polynuclear aromatic hydrocarbons such as benzo[ $a]$ pyrene (BAP). In both mammals and fish, the AHR is required for TCDD toxicity (FernandezSalguero et al., 1996; Prasch et al., 2003). Early work in F. heteroclitus provided evidence for an AHR protein (Hahn et al., 1994; Willett et al., 1995). Subsequently, F. heteroclitus was the first species in which multiple AHR genes were identified (Hahn et al., 1997; Karchner et al., 1999). AHR1 and AHR2 are highly divergent AHR paralogs that are differentially-expressed (Karchner et al., 1999). Enhanced AHR diversity was subsequently found to be a general characteristic of fishes (reviewed in Hahn, 2002; Hahn et al., 2006). In addition to having multiple AHR genes, F. heteroclitus also possesses greater allelic diversity at AHR loci as compared to mammals (Hahn et al., 2002; Yang, 2003; Cohen et al., 2006; Hahn et al., 2004). At the population level, in a broad survey of 23 populations from South Carolina to New Hampshire, there were more than 12 single nucleotide polymorphisms in a 512 nucleotide segment of the transactivation domain found in exon 10 of AHR1 (Cohen et al., 2006). In another study examining full-length coding sequences of AHR1, AHR2, and AHR repressor (AHRR) in seven populations of $F$. heteroclitus, all three loci were highly polymorphic (AHR1: 45 SNPs; AHR2: 30 SNPs; AHRR: 38 SNPs) (Hahn et al., 2005). For AHRl and $A H R 2$, the distribution of SNPs and inferred haplotypes (specific arrangements of SNPs on a single chromosome) varied significantly among sites.

Other bHLH-PAS proteins characterized in F. heteroclitus include the AHR dimerization partner ARNT2 (Powell et al., 1999), an AHR repressor (AHRR) (Karchner et al., 2002), and hypoxia-inducible factor (HIF $\alpha$ ) (Powell and Hahn, 2002). AHRR inhibits transcriptional activation by both AHR1 and AHR2, and is induced by exposure to AHR agonists (Karchner et al., 2002). Thus, it appears to be part of a negative regulatory loop that controls the AHR signaling pathway. Although not directly a target for chemicals, HIF proteins are toxicologically relevant because of potential cross-talk with AHR signaling during fish development (Powell et al., 2002; Powell and Hahn, 2002; Meyer and Di Giulio, 2003; Kraemer and Schulte, 2004; Prasch et al., 2004).

Evidence in mammals and selected model systems suggests that the dimeric transcription factor HIF is a master regulator of gene expression during hypoxia (Wenger et al., 2005). In mammals, at least 70 genes are known to be regulated by HIF, and the list includes genes involved in oxygen delivery (erythropoietin), vasculogenesis (vascular endothelial growth factor), carbohydrate metabolism (glucose transporters and several glycolytic enzymes), and many other functions (Wenger et al., 2005; Gorr et al., 2006). The HIF dimer is composed of an $\alpha$ subunit, of which there are three described forms (HIF-1 $\alpha$, HIF- $2 \alpha$, and HIF-3 $\alpha$ ), and a $\beta$ subunit (HIF- $\beta$, also known as the aryl hydrocarbon receptor nuclear translocator, ARNT). Oxygen-sensitivity of HIF signaling is conferred by oxygendependent degradation of HIF- $\alpha$ subunits by the ubiquitinmediated proteosomal pathway. There are several excellent recent reviews of HIF signaling in mammals (Berra et al., 2005; Hirota and Semenza, 2005; Schofield and Ratcliffe, 2005; Wenger et al., 2005).

Homologs of HIF have been identified in a handful of teleost fish (reviewed in Nikinmaa and Rees, 2005). Three forms of $\alpha$ subunit have been described in F. heteroclitus; these apparently correspond to homologs of mammalian HIF-1 $\alpha$ and HIF- $2 \alpha$, and a third form that may be fish-specific (Powell and Hahn, 
2002 and B.B. Rees, S.I. Karchner, E. Skripnikova, and M.E. Hahn, unpublished data; Law et al., 2006). Only a single form of ARNT, ARNT2, has been reported for $F$. heteroclitus (Powell et al., 1999); it interacts with HIF-2 $\alpha$ to bind the mammalian HIF-binding consensus DNA sequence (Powell and Hahn, 2002). Although there are several putative targets of HIF regulation in fish (Nikinmaa and Rees, 2005), direct interaction with HIF has been demonstrated for only a limited number of fish genes (Kajimura et al., 2006). One putative target gene is the liver form of lactate dehydrogenase, LDH-B (Rees et al., 2001) one of the glycolytic enzymes upregulated by hypoxic exposure of $F$. heteroclitus and $F$. grandis. Deletion and mutation analysis of the $L d h-b$ promoter has identified a HIFbinding region (B.B. Rees, Y.G. Figueroa, T.E. Wiese, B.S. Beckman, and P.M. Schulte, unpublished data). Interestingly, the DNA sequence of this region is not the consensus sequence described for mammalian target genes (Wenger et al., 2005), suggesting that a broader taxonomic view of HIF function will reveal greater diversity of HIF targets.

\subsection{Cytochrome P450s}

CYP enzymes catalyze oxidative transformation of the structure of organic chemicals by monooxygenase reactions, involving scission of molecular oxygen and fixation of an oxygen atom into the structure (De Montellano, 1995). Currently, there are more than 6000 named genes in the CYP gene superfamily with members in archaea, bacteria, plants and animals (http:// drnelson.utmem.edu/P450.stats.2006.htm). Multiple CYP genes occur in animals, and in vertebrates CYP enzymes are expressed in some cell types in all organs of the body.

Substrates for CYP enzymes include an astonishing number and diversity of moderately or highly lipophilic compounds of physiological and toxicological significance. In animals, CYP enzymes involved in the synthesis and transformation of endogenous regulatory molecules (steroids, retinoids, fatty acids etc) often have narrower substrate specificity than those CYP that also have evolved functions with exogenous toxic chemicals or xenobiotics, whether of biological or anthropogenic origin. The enzymes having broad substrate specificity with toxic chemicals are principally in CYP gene families 1-3. CYP activities with exogenously derived substrates might be considered primarily as adaptive functions, involving the protection against toxic chemicals, although metabolism can activate some compounds to derivatives that are more reactive and more toxic (Guengerich and Liebler, 1985).

The full complement of CYP genes has not been established in killifish. To date, F. heteroclitus CYP genes identified by cloning and sequencing occur in twelve CYP families: CYP1, CYP2, CYP3, CYP4, CYP5, CYP7, CYP8, CYP17, CYP19, CYP24, CYP46, and CYP51. By comparison with other fish species whose genomes have been sequenced, the pufferfishes Takifugu rubripes and Tetraodon nigroviridis, and the zebrafish (D. rerio), we can anticipate 60 to 80 or more CYP genes in $F$. heteroclitus. We can anticipate these genes will occur in the same 18 CYP gene families seen in mammals, although only 17 of the 18 mammalian CYP families have been reported in the pufferfish T. rubripes. CYP39 is the only family not found in pufferfish (Nelson, 2003), although it has been detected in other fish.

CYP gene diversity known to date in F. heteroclitus varies among the gene families. Among the steroidogenic enzymes, there are duplicated CYP19 (aromatase) genes in F. heteroclitus, with one (CYP19A) expressed predominantly in the ovary and the other (CYP19B) in the brain (Greytak et al., 2005); in mammals there is a single CYP19. CYP19B, but not CYP19A, is estrogen-inducible and is more highly expressed than CYP19A. CYP19 gene duplicates with subdivided expression domains is a general characteristic of teleosts (Engle and Callard, 2007), and the expressed isozymes differ in their kinetic parameters and responses to known aromatization inhibitors and phytoestrogens (Zhao et al., 2001).

Among the toxicologically important gene families, we know most about the CYP1 genes. Among these are the CYP1A enzymes that metabolize aromatic and chlorinated hydrocarbon pollutants and that are induced by these chemicals via the $\mathrm{AH}$ receptor. There is a growing diversity of CYP1 family genes in fishes; recent studies show that fish express four genes in three CYP1 subfamilies, CYP1A, CYP1B1 and CYP1C1 and CYP1C2 (Godard et al., 2005); three of these have been studied in killifish (Wang et al., 2006). Functions of these newer CYP1s are not yet known.

There are paralogous CYP3A genes in F. heteroclitus, CYP3A30 and CYP3A56, with one expressed more in intestine and one in liver (Hegelund and Celander, 2003). Several other fishes have been found to have two CYP3A genes, which in phylogenetic analysis appear to have resulted from separate duplications. However, it is possible that gene conversion may be masking orthologous relationships among these CYP3As and giving the appearance of independent paralog pairs (Kashiwada et al., 2005; Goldstone and Stegeman, 2006).

In other vertebrates the CYP2 and CYP4 families show the greatest degree of diversity, and the number of CYP2 subfamilies identified in F. heteroclitus so far (seven) suggests that this family is highly diverse in killifish as well. Notably, some CYP2 gene subfamilies were identified first in killifish, including the CYP2Ps and CYP2Ns (Oleksiak et al., 2000, 2003). These subfamilies are closely related to the mammalian CYP2Js, and are among the fish CYP2 subfamilies showing the greatest diversity. The functional significance of this diversity is not known; however, the enzymatic properties of the CYP2Ps and the CYP2Js are very similar with respect to arachidonic acid metabolism, suggesting that fundamental aspects of the role of these CYPs are conserved. Finding shared synteny in other species (J.V. Goldstone and J.J. Stegeman, unpublished data) suggests that the CYP2Ps are orthologous to the CYP2Js and that the fundamental biological roles of these enzymes may be approached by studies in F. heteroclitus. Some CYP2s may be inducible by environmental chemicals (Peterson and Bain, 2004) and, as with other CYP, there are numerous variables also to be considered in CYP2 regulation, exemplified by studies of CYP2K activities (Haasch, 2002).

While multiple CYP genes have been identified in $F$. heteroclitus based on sequence identities, details of function and 
regulation are known for few of these. Functional studies have been done with microsomal preparations, and on some that have been expressed in heterologous systems, e.g., the CYP2Ns, CYP2Ps, and CYP51 (Oleksiak et al., 2000, 2003). For Fundulus, fundamental questions remain concerning the identity and number of CYP, their catalytic functions, their regulation and expression, their evolution and inter-relatedness, and finally, their endogenous functions. There is likely complex sharing of functions of many CYPs with endogenous and exogenous substrates, and multiple modes of regulation for individual genes. Thus, the same CYP that oxidize xenobiotics also metabolize a broad range of endobiotic substrates including hormones, bile acids, lipids, arachidonic acid and others, and it has been suggested that all CYP may have some endogenous function (Nebert and Russell, 2002).

The role of these receptors, transcription factors, biotransformation enzymes and their regulatory networks is still poorly understood in fish and thus remains a rich source of research questions. The availability of improved genomic resources will provide powerful tools to understand, for example, whether receptor paralogs such as AHR1 and AHR2 (or ERßa and $\mathrm{ER} \beta \mathrm{b}$ ) regulate distinct or overlapping target genes, or whether there are ligand-specific gene expression profiles. Genomic tools also will facilitate mechanistic studies of cross-talk among receptor types (e.g. AHR-HIF, AHR-ER, ER-ERR) and how this influences adaptation to environments when multiple stressors co-occur.

\section{Toxicology}

Because of its ecological importance, Fundulus was recognized early as an important laboratory model to evaluate the toxicity of environmental pollutants (reviewed in Eisler, 1986). F. heteroclitus is widely used for marine toxicology studies. A search of the US Environmental Protection Agency's database of aquatic toxicity testing (ECOTOX) reveals over 1000 studies using this species. Consistent with its reputation as hardy, adult Fundulus are relatively insensitive to lethal effects of some chemicals. In fact, an analysis of ECOTOX reveals that $F$. heteroclitus was ranked among the most sensitive species (top $25 \%$ ) for only two out of 17 chemicals tested, and typically ranked in the third quartile (50-75\%) for sensitivity among tested species. While this sample is small and potentially biased by the use of various chemicals, exposures, and lifestages, these results suggest that chemical sensitivities for $F$. heteroclitus are not universally high but vary by compound. During early life stages, killifish are among the more sensitive fish species to the extremely toxic dioxin-like compounds (DLCs), ranking third when compared to ten freshwater fish species tested similarly (reviewed in Van Veld and Nacci, in press). However, unlike other teleost species, some populations of $F$. heteroclitus have also demonstrated an 'evolved tolerance' to DLCs (see below, Evolved tolerance to polluted habitats).

Because of their usefulness as a laboratory model and a representative ecological model, embryos and larvae of $F$. heteroclitus have been used to assess the toxicity of single chemicals, chemical mixtures and environmental samples
(Crawford and Guarino, 1976; Weis and Weis, 1977; Sharp and Neff, 1982; Khan and Weis, 1987a; Zhou et al., 1999, 2001; Couillard, 2002; Nacci et al., 2002b; Wassenberg and Di Giulio, 2004a; Wassenberg et al., 2005; Arzuaga et al., 2006; Gonzalez et al., 2006; Timme-Laragy et al., 2006). As described above (Reproduction and Development), embryonic development is well-characterized and easily observable. Furthermore, biomarkers of xenobiotic exposure such as CYP1A inducibility are measurable early in the embryonic period and can be quantified using traditional measures of enzyme activity (e.g., Binder and Stegeman, 1980) or immunodetectable CYP1A protein (Van Veld et al., 1992, 1997; Toomey et al., 2001). Similarly, the predominant brain form of aromatase CYP19B mRNA is a sensitive and robust biomarker of environmental estrogen in both adult and larval killifish (Greytak et al., 2005; Greytak and Callard, 2007). In addition, novel non-invasive methods have been developed for quantifying the activity of contaminantinducible embryonic enzymes to assess variation in sensitivity to contaminants among embryos and populations (Nacci et al., 1998, 2005; Arzuaga et al., 2006).

\subsection{Reproductive and developmental effects}

The sensitivity of $F$. heteroclitus, as well as its suitability and flexibility for field and artificial stream studies and for laboratory bioassays, has allowed demonstration of reproductive effects at various locations, determination of mechanisms responsible for reproductive effects, and demonstration of recovery in reproductive function following process changes.

In both laboratory and field studies, killifish have been used to document effects of environmental chemicals on many different end-points of reproduction and development such as viability and fertilizability of eggs and sperm (Khan and Weis, 1987a), cytogenetic effects (Crawford and Guarino, 1976; Perry et al., 1988; Black et al., 1998a,b), embryo mortality, rate of development, developmental deformities, time to hatching and hatching success (Weis and Weis, 1974; Crawford and Guarino, 1976; Weis and Weis, 1977; Black et al., 1998a,b; Ownby et al., 2002; Boudreau et al., 2004; Wassenberg and Di Giulio, 2004b; Boudreau et al., 2005; Wassenberg et al., 2005; Gonzalez et al., 2006; Timme-Laragy et al., 2006), as well as larval growth, spontaneous activity, prey-capture ability, startle response, learning ability, neurotransmitter levels (Zhou et al., 1999; Zhou et al., 2001; Weis et al., 2003; Timme-Laragy et al., 2006) and sex ratios (Matta et al., 2001). End-points used to assess reproductive condition of sexually mature adults include reproductive success, circulating sex steroids, gonadal size, hepatic size, yolk protein synthesis, and genetic markers such as CYP19 aromatases, ER and vitellogenin (Black et al., 1998a,b; Monteverdi and Di Giulio, 2000; Matta et al., 2001; MacLatchy et al., 2003; Boudreau et al., 2004; Boudreau et al., 2005; Greytak et al., 2005; Greytak and Callard, 2007).

Studies on pulp and paper mill effluents have identified reproductive effects in fish, linked to the presence of endocrineactive contaminants in marine and estuarine environments (Hewitt et al., 2005). Studies in the field (LeBlanc and Bain, 1997), artificial streams (Dubé and MacLatchy, 2000) and 
laboratory (Dubé et al., 2002; Hewitt et al., 2002; Belknap et al., 2006; Shaughnessy et al., 2007) have identified reproduction and endocrine effects in $F$. heteroclitus as sensitive end-points that are responsive to endocrine-active contaminants in pulp mill effluents. These studies in killifish have led the way in determining the source(s) of contaminants within the mill process as well as confirming, for the purposes of environmental protection, an effective within-mill treatment process to remove the contaminants (Dubé and MacLatchy, 2001; Hewitt et al., 2002).

AHRs, ERs, or other receptors could mediate at least some effects of environmental chemicals on these reproductive and developmental end-points. Dioxins, PCBs, pesticides, plasticizers, pharmaceuticals, heavy metals and other chemicals that accumulate in the environment are known to disrupt processes of reproduction and development, even at low doses and after transient exposures, by virtue of their ability to mimic or block hormone actions on cognate receptors or otherwise alter hormone-mediated signal transduction (reviewed in Phillips and Harrison, 1999; Sumpter and Johnson, 2005). Although the "endocrine disruptor hypothesis" is still debated in the context of human health (Crisp et al., 1998; Safe, 2004), studies of fieldcollected $F$. heteroclitus reveal clear signs of receptor-dependent chemical effects. For example, killifish inhabiting sites contaminated by PCBs or petroleum-derived PAHs exhibit elevated CYP1A levels (Stegeman, 1978; Elskus and Stegeman, 1989; Teal et al., 1992). In F. heteroclitus resident in New Bedford Harbor (NBH), markers of estrogen effect, P450aromB and vitellogenin, are inappropriately elevated in males, signifying an "estrogenic environment" (Greytak et al., 2005; see below Section 5.1.2. for additional details). PCBs, the major NBH contaminant, or their in vivo metabolites, are known to interact with ER. Not surprisingly, the hypothalamic-pituitarygonadal axis is functionally impaired in NBH fish during the breeding season (Greytak et al., 2005).

Changes in reproductive parameters of sexually mature killifish at sites other than NBH have also been reported (LeBlanc et al., 1997; Rice and Xiang, 2000; McArdle et al., 2004). Additionally, reproductive and biomarker changes similar to those observed in wild-caught fish can be induced in the laboratory by administering hormonal estradiol-17 $\beta$, PCB mixtures, ethinylestradiol, BAP, 4-nonylphenol, 4-(tertoctyl)phenol, bisphenol-A and DDT, as well as the androgen methyl testosterone and the anti-androgen cyproterone acetate (Crawford and Guarino, 1976; Black et al., 1998a; Matta et al., 2001; MacLatchy et al., 2003; Pait and Nelson, 2003; Sharpe et al., 2004; Patel et al., 2006). Furthermore, early exposure to estrogenic compounds has been shown to cause developmental deformities in the vertebrae and cranial bones in developing $F$. heteroclitus, as well as soft tissue abnormalities (Urushitani et al., 2002).

\subsection{Effects on immunocompetence}

Fundulus was one of the first fish species used as a model to study the links between pollution, immune response, and disease susceptibility (Fries, 1986). Basic parameters of immune function, from phagocytosis and respiratory burst to antibody production, have been evaluated as biomarkers of environmental stress. In general, exposure to pollutants and other stressors led to a decrease in immune function (Fries, 1986; Faisal et al., 1991; Fournier et al., 1998; Baier-Anderson et al., 2000; Rice and Xiang, 2000; Boleza et al., 2001). However, some differences in the results between in vivo and in vitro exposures suggest modulation of certain immune parameters in vivo (Roszell and Anderson, 1993; Roszell and Anderson, 1994; Roszell and Anderson, 1996), or differences in the responses to the complex mixtures of contaminants present in the field (Kelly-Reay and Weeks-Perkins, 1994). Some of these seemingly contradicting results also might be explained by the influence of the endocrine system and circadian rhythm on the immune response (Nevid and Meier, 1995; Fournier et al., 1998; Rice and Xiang, 2000). These studies point to the need to consider these factors when using parameters of the killifish immune system as biomarkers of exposure to environmental stress. Furthermore, there is a need to develop tools to evaluate parameters of both the innate and the adaptive arms of the immune system, as well as tests to evaluate the functional consequences of immune change in populations of killifish that have adapted to environmental stressors.

\subsection{Carcinogenesis}

F. heteroclitus is currently the only known species exhibiting neoplasia in natural populations that also is amenable to laboratory studies. The killifish is, therefore, the best available model system to verify the putative cause-effect relationship between contaminant exposure and carcinogenesis in wild fishes.

Since 1990, the association between exposure to polycyclic aromatic hydrocarbons (PAHs) and development of a suite of toxicopathic liver lesions has been investigated in F. heteroclitus populations in the Elizabeth River (see below, Section 5.1.3). F. heteroclitus inhabiting the intertidal nearshore habitat in proximity to facilities of Atlantic Wood Industries exhibit a high prevalence of toxicopathic liver disease including a suite of neoplastic and pre-neoplastic hepatocellular and cholangiocellular lesions (Vogelbein et al., 1990, 1999), a wide range of nonneoplastic hepatic lesions (Vogelbein and Unger, 2006), exocrine pancreatic neoplasms (Fournie and Vogelbein, 1994; Vogelbein and Fournie, 1994) and vascular neoplasms (Vogelbein et al., 1997). Hepatocellular lesions include a suite of altered hepatocellular foci (e.g., eosinophilic, basophilic, clear cell, vacuolated, and amphophilic foci), hepatocellular adenoma, hepatocellular carcinoma and hepatoblastoma (Vogelbein et al., 1990; (Vogelbein and Unger, 2006). Cholangiocellular lesions include cholangiofibrosis, cholangioma and cholangiocarcinomas. Among pancreatic neoplasms acinar cell adenomas and carcinomas have been identified, and vascular neoplasms include hemangioendothelioma, hemangiosarcoma and hemangiopericytic sarcoma (Vogelbein and Zwerner, 2002). Field surveys within the Elizabeth River and in other chemically impacted parts of the Chesapeake Bay, US, indicate a strong association between PAH exposure and toxicopathic liver disease, with liver lesion prevalence and severity tracking a sediment PAH gradient. 
Elizabeth River F. heteroclitus have developed resistance to the acutely toxic components of creosote that has, in part, a genetic basis (Mulvey et al., 2002; Ownby et al., 2002; Mulvey et al., 2003). Because offspring of these fish are highly resistant to the acutely toxic components of creosote, this has provided an opportunity to conduct long-term studies to evaluate the carcinogenicity of the river sediments near one of the wood treatment facilities. Following a year-long sediment and dietary exposure regimen, fish developed a high $(40 \%)$ prevalence of altered hepatocellular foci and a moderate level of hepatic neoplasms (8.7\%) (Vogelbein and Unger, 2006). This has provided some of the strongest direct experimental evidence for a cause and effect relationship between chronic PAH exposure and fish neoplasia to date.

\subsection{Toxicant-altered gene expression}

Changes in gene expression in $F$. heteroclitus have been used to monitor exposure to contaminants and as an index of the adaptability of natural populations to environmental stressors. The influence of physical environmental variables and chemical contaminants on CYP gene expression were documented early in this species (Stegeman, 1979; Kloepper-Sams and Stegeman, 1989; Kloepper-Sams and Stegeman, 1992). F. heteroclitus has been a particularly effective model for analyzing induction of CYP1A in multiple organs as a marker of activation of the AHR, environmental exposure of animals to biochemically active levels of AHR agonists and resistance adaptation (Elskus and Stegeman, 1989; Van Veld et al., 1992, 1997; Nacci et al., 1999; Bello et al., 2001; Meyer et al., 2002). One of the recently identified members of the CYP 1 family, CYP1C1, also is inducible by aromatic hydrocarbons in F. heteroclitus (Wang et al., 2006), indicating possible involvement in toxic effects.

Differential display and subtractive hybridization have been used to examine up- or downregulation of known and novel mRNAs in toxicant-exposed $F$. heteroclitus. A number of genes, including UDP-glucose pyrophosphorylase, glucose 6phosphatase, plasma coagulation factor XI, SET protein, translocon-associated protein, and three ESTs, were differentially-expressed in $F$. heteroclitus obtained from the PAHimpacted Atlantic Wood Superfund site in the Elizabeth River, Virginia, compared to fish from a reference site (Meyer et al., 2005; see Section 5.1.3 for additional details). Alterations in novel mRNAs associated with laboratory exposure to the PAH anthracene (Peterson and Bain, 2004) and to trivalent chromium (Maples and Bain, 2004) were confirmed in F. heteroclitus from field sites contaminated with PAHs and chromium. Roling et al. (2004) used subtractive hybridization to correlate differential gene expression with laboratory exposure to pyrene in $F$. heteroclitus from a PAH-impacted site. Similarly, Gonzalez et al. (2006) used subtractive hybridization to show that $F$. heteroclitus exposed to arsenic during gametogenesis had offspring that upregulated myosin light chain 2, type II keratin, and tropomyosin, which correlated to an increase in trunk curvature.

A 542 spot cDNA array was used to assess differences in fish exposed in the laboratory to chromium complexes, including $\mathrm{Cr}$
(III) and $\mathrm{Cr}(\mathrm{VI})$, and arsenic, and in fish collected from field sites that are impacted with metals. Differential gene expression was observed between $F$. heteroclitus exposed to $\mathrm{Cr}$ (III) or $\mathrm{Cr}$ (VI) at the no-observable and lowest-observable effect concentrations (Roling et al., 2006; Roling and Baldwin, 2006). Cr(III) altered the expression of several glutathione $S$ transferases (GSTs) (Roling and Baldwin, 2006), while Cr(VI) altered the expression of genes involved in growth, energy metabolism, and to a lesser extent detoxification genes. Both larval and adult $F$. heteroclitus had perturbed expression of metabolic genes, while only larvae showed changes in GST expression following $\mathrm{Cr}(\mathrm{VI})$-exposure (Roling et al., 2006). In addition, cDNA microarrays were used in combination with chemistry data as a weight-of-evidence approach to demonstrate that remediation progressed as anticipated at a chromiumcontaminated Superfund site in Charleston, SC (Roling et al., 2007).

Very recently, Fisher and Oleksiak (2007) used a cDNA microarray containing 384 metabolic genes from liver and heart to compare gene expression in brains of $F$. heteroclitus collected from three polluted sites and six reference sites. The fish had been held in the laboratory under identical conditions for one year before analysis. The results showed that up to $17 \%$ of metabolic genes had evolved adaptive changes in gene expression in the populations inhabiting the polluted sites.

Thus, while some inroads have been made in understanding responses to toxicant exposure in natural populations, the questions that remain to be addressed rely on a new generation of genomic technologies that are in early stages of development. When applied to a powerful model organism such as $F$. heteroclitus and related species, genomics-based tools can have a critical role in elucidating unique pathways of toxicant action and response, revealing information on alterations in reproductive, health and immune status, and in monitoring remediation in natural environments.

\section{Ecological and evolutionary genetics}

Studies with $F$. heteroclitus have provided unique insights in the area of ecological and evolutionary genetics. Here, variation among natural groups and populations has permitted an unparalleled examination of environmental influences on the genome along physiological timescales (acclimation responses) to evolutionary timescales (heritable adaptive responses). Compared to genomics studies in traditional model species, a far richer understanding of genome-environment interactions can be derived from studies of natural populations of outbred species such as $F$. heteroclitus that are routinely exposed to stressors within an ecological context. Indeed, by nature of the dynamic and variable estuarine habitat which they occupy, $F$. heteroclitus exhibits extraordinary physiological resilience and has evolved tolerances to extremes of temperature, salinity, dissolved oxygen, and pollutants. Furthermore, F. heteroclitus is one species among many other closely and more distantly related Fundulus species that vary in physiological abilities and ecological niches occupied. This network of relationships make the Fundulidae particularly powerful for evolutionary and 
physiological studies (Powers et al., 1991; Crawford et al., 1999a; Whitehead and Crawford, 2006b). Here we highlight several areas in which unique attributes of Fundulus species as individuals and populations have proved crucial to our understanding of ecological and evolutionary genetics.

\subsection{Evolved tolerance to polluted habitats}

Although adaptation in the wild is difficult to prove, the occurrence of large, persistent populations of non-dispersive Fundulus species in highly contaminated estuaries, provides suggestive evidence of genetic adaptation (Endler, 1986). Weis and Weis (1989) reviewed much of the early literature on toxicity resistance in fish, providing some of the first and most intriguing evidence concerning the genetic, biochemical, and ecological mechanisms of tolerance in killifish. Three notable examples in which natural Fundulus populations exposed to chemical contaminants have provided unique insights into adaptation and tolerance are highlighted here.

\subsubsection{Tolerance to mercury and TCDD (Newark, NJ, USA)}

F. heteroclitus resident to Piles Creek, NJ, a small industrialized tributary contaminated with a variety of metal and organic pollutants, have been the subject of studies on the genetic, biochemical and ecological mechanisms of tolerance to the highly toxic methyl mercury. Embryos and gametes of this F. heteroclitus population are resistant to methyl mercury toxicity, but later life stages are not, and the adaptation appears to have a genetic basis (Weis et al., 1981; Khan and Weis, 1987b; Weis and Weis, 1989; Weis et al., 2001; Weis, 2002). The resistance exhibited by Piles Creek embryos is based in part on reduced chorionic permeability (Weis et al., 1981) and in part on an increased rate of development (Toppin et al., 1987). This altered rate of embryonic development may protect the highly sensitive embryos by decreasing the time over which they are exposed to methyl mercury. Some evidence suggested that the resistant phenotype in the embryos appeared to be inherited primarily maternally, not paternally, and was correlated with finray count, a characteristic believed to have a large genetic component (Weis et al., 1982). However, additional evidence indicated that methyl mercury-resistant gametes were also produced by resistant adults of both sexes (Khan and Weis, 1987b).

Following reports of mercury tolerance in $F$. heteroclitus from Newark Bay, Prince and Cooper (1995a,b) documented tolerance to TCDD in the same species collected from another site in Newark Bay. TCDD effects could not be accounted for by differences in TCDD uptake between fish from Newark Bay and reference sites. F. heteroclitus from Newark Bay were unresponsive to the induction of the AHR-mediated detoxification enzyme CYP1A following exposure to TCDD, toxicologically-similar DLCs, or other AHR agonists (Prince and Cooper, 1995a; Elskus et al., 1999; Arzuaga and Elskus, 2002), suggesting that an altered AHR pathway may be involved in resistance to DLCs. Newark Bay F. heteroclitus had slightly lower levels of overall AHR protein expression and DNA methylation did not appear to play a role in AHR pathway functionality in Newark Bay populations (Arzuaga and Elskus, 2002; Arzuaga et al., 2004).

\subsubsection{Tolerance to PCBS (New Bedford Harbor, MA, USA)}

Toxicity and tolerance to DLC has also been investigated in F. heteroclitus resident to New Bedford Harbor (NBH), designated a Superfund site because of widespread and very high levels of PCB contamination (Pruell et al., 1990; Lake et al., 1995; Nelson et al., 1996; Black et al., 1998a). Sediment PCB levels as high as $190,000 \mathrm{mg}$ PCB $/ \mathrm{kg}$ sediment or $19 \%$ by weight have been documented in the most contaminated areas of NBH (Weaver, 1982). F. heteroclitus inhabiting sites throughout NBH are exposed to DLC (Lake et al., 1995; Black et al., 1998a) exceeding levels that were lethal to fish from clean reference sites exposed via injection (Black et al., 1998a) or diet (Gutjahr-Gobell et al., 1999). Lethal concentrations between tolerant and sensitive populations differed by orders of magnitude, and exceeded the estimated range in sensitivities for all fish species tested for this category of pollutant (reviewed in Van Veld and Nacci, in press). Despite high tissue concentrations of DLCs, NBH $F$. heteroclitus are reproductively prolific (Nacci et al., 2002c) and have high condition indices (Nacci et al., 2001). Additional evidence suggests that demographic compensation, such as increased reproductive effort and/or migration, do not play important roles in supporting a persistent population in NBH (Nacci et al., 2002b; Nacci et al., 2002c; Nacci et al., in press). The history of site-specific pollution indicates that adaptation occurred relatively recently, within the past 50 years (Nacci et al., 2002b). Two generations of laboratory-bred $F$. heteroclitus from the PCB-contaminated NBH site were similarly insensitive to the lethal effects of PCBs in relation to two generations of $F$. heteroclitus from a nearby reference site (Nacci et al., 2002a). Thus, heritable adaptation through chemical tolerance to PCBs provides the best explanation for persistence of the $\mathrm{NBH}$ mummichog population. In this case, the magnitude of difference in sensitivities among populations suggests that the strength of selection for this evolved tolerance can be very large, and reflects a selective force much greater than typically demonstrated by natural agents (Kingsolver et al., 2001).

DLC resistance in NBH $F$. heteroclitus involves alterations in responsiveness of the AHR pathway in adults (Bello, 1999; Nacci et al., 1999; Bello et al., 2001; Karchner et al., 2002) as well as in embryos (Nacci et al., 1998; Roark et al., 2005). Exposure to BAP caused fewer DNA adducts in NBH fish relative to reference fish (Nacci et al., 2002c), consistent with an altered AHR pathway. Like parental fish, progeny from NBH were generally refractory to CYP1A induction suggesting that some mechanisms of tolerance are inherited (Bello, 1999). Other evidence suggested that short-term or non-heritable mechanisms may contribute to the observed differences between the NBH and reference fish. For example, freshly caught NBH fish had lower hepatic content of AHR than reference fish, but the difference was no longer detected after a 90 day depuration period in the laboratory (Bello, 1999). The DLC-tolerant phenotype of adults is not accompanied by changes in the expression of mRNA for AHR (AHR1 and AHR2), partner (ARNT), or repressor (AHRR) 
pathway components (Powell et al., 2000; Karchner et al., 2002). Recent studies have demonstrated that the AHR1 locus is highly polymorphic in Fundulus, and that there are different allele frequencies in DLC-sensitive and tolerant populations (Hahn et al., 2002; Yang, 2003; Hahn et al., 2004; S. Cohen, G. Yang, S.M. Tam, D. Champlin and D. Nacci, unpublished data) but some of the AHR1 protein variants encoded by these alleles do not display functional differences (Hahn et al., 2004). In broad geographic comparisons of a total of 22 contaminated and reference populations, significant differences in patterns of nonsynonymous versus synonymous substitutions in the transactivation region of the transcription factor AHR1 suggest that changes in selective pressures related to the AHR pathway are altering these allelic frequencies between sites (S. Cohen, G. Yang, S.M. Tam, D. Chaplin and D. Nacci, unpublished data). The AHR2 locus also is highly polymorphic and exhibits differences in allele frequencies among sensitive and tolerant populations of $F$. heteroclitus (Hahn et al., 2005). In light of the demonstrated role of AHR2 in DLC embryotoxicity in other fishes (Prasch et al., 2003), AHR2 variants may be more likely to be involved in the mechanism of resistance.

In contrast to AHR expression, which does not differ in embryos from NBH compared to those from a reference site (Powell et al., 2000), ER $\alpha$ expression is site-related (Greytak and Callard, 2007). Paradoxically, ER $\alpha$, which is estrogeninducible in teleosts, is hyporesponsive to estradiol in NBH embryos (Greytak and Callard, 2006). It may also be relevant that estrogen induction of vitellogenin is reduced in sexually mature fish. Furthermore, F. heteroclitus CYP19B, an estrogenresponsive gene in teleosts, was approximately two-fold higher in the brain of fish from NBH than in reference site fish (Greytak et al., 2005), while Patel et al. (2006) observed that ovarian aromatase activity was significantly decreased by $10 \mu \mathrm{g}$ $\mathrm{L}^{-1}$ BAP. Although endocrine disruptor research has focused mainly on estrogen-like chemicals and ER signaling, the possibility that killifish reproductive success is impacted by pollutants acting on androgen receptors (Sharpe et al., 2004; Boudreau et al., 2005) or thyroid receptors (Carletta et al., 2002) cannot be ruled out. By analogy to acquired resistance to AHRmediated chemical effects in populations at this and other polluted sites, it will be of interest to determine whether longterm exposure to an environment with hormone mimics leads to adaptive changes in hormonal signaling which, in turn, lead to changes in reproductive success.

\subsubsection{Tolerance to PAHs (Elizabeth River, VA, USA)}

$F$. heteroclitus has adapted to life in an inlet near Norfolk, VA, that is contaminated with very high levels of creosoteassociated and other chemicals, especially PAHs (Bieri et al., 1986; Padma et al., 1998). Despite a very high prevalence of liver and pancreatic lesions and neoplasms in adults (see above, Carcinogenesis), the Atlantic Wood (AW) population appears to be thriving. Individuals are resistant to the toxicity exerted by the sediments from the site, which are teratogenic to embryos and lethal to embryos and larvae bred from adult fish collected from reference sites (Meyer and Di Giulio, 2002; Ownby et al., 2002; Meyer and Di Giulio, 2003). AW F. heteroclitus display deviations in several biochemical parameters that could be related to their ability to survive in their contaminated environment, including increased expression of GST and pglycoprotein (Van Veld et al., 1991; Cooper et al., 1996; Armknecht et al., 1998; Cooper et al., 1999), increased hepatic UDP-glucuronyltransferase (Gaworecki et al., 2004), and increased hepatic anti-oxidant defenses (Meyer et al., 2003; Bacanskas et al., 2004). AW fish exhibit decreased inducibility of CYP1A mRNA and protein and decreased catalytic activity (Van Veld and Westbrook, 1995; Meyer and Di Giulio, 2002; Meyer et al., 2002). However, many of these changes are not heritable and thus cannot completely explain the resistant phenotype, which is at least partly heritable (Meyer and Di Giulio, 2002; Ownby et al., 2002; Meyer and Di Giulio, 2003).

While it was initially hypothesized that poor CYP1A inducibility promoted a fitness advantage via reduced metabolism of PAHs to teratogenic or lethal products, studies to assess the impacts of AW sediments on early life stage development and survival failed to support this contention (Meyer et al., 2002). Subsequent studies with pure compounds demonstrated marked synergistic toxicities between PAHs or PAH-like compounds that act as AHR agonists and other PAHs that inhibit CYP1A (Wassenberg and Di Giulio, 2004b). These studies included the model PAH-like compounds $\beta$-naphthoflavone (BNF, an AHR agonist) and $\alpha$-naphthoflavone (ANF, a CYP1A inhibitor) (Wassenberg and Di Giulio, 2004a) and environmentally-relevant PAHs, such as BAP (AHR agonist) and fluoranthene (CYP1A inhibitor) (Wassenberg et al., 2005). Collectively these and other studies suggest that some PAHs exert developmental effects via activation of the AHR, and that CYP1A plays a protective role via metabolism of AHR agonists. In addition to gaining insight into the adapted AW F. heteroclitus phenotype, this synergy has important implications for risk assessment. PAHs invariably occur as mixtures and current approaches for estimating the ecological risks of these mixtures assume additive toxicities of mixture components (Swartz, 1999; Barron et al., 2004).

These highlighted examples document both adverse and compensatory responses to chemical exposures using wild $F$. heteroclitus populations, illustrating not only mechanisms but costs of rapid adaptation. For example, an important potential fitness cost that is hypothesized to occur in response to intense selection is reduced genetic diversity. However, evidence does not support this hypothesis for the AW (Mulvey et al., 2002, 2003) or NBH (Cohen, 2002; Mulvey et al., 2003; Roark et al., 2005; McMillan et al., 2006) F. heteroclitus populations. In addition, there was no loss of genetic diversity in broader geographic surveys (3-22 populations) of contaminated and reference locations in comparisons of several loci including: a portion of the AHR1 locus, the mitochondrial d-loop, and $\mathrm{MH}$ Class II intron and exon segments (Cohen, 2002; Cohen et al., 2006; Yang, 2003; Tirindelli, 2007; S. Cohen, G. Yang, S.M. Tam, D. Chaplin and D. Nacci, unpublished data). While the mechanisms of adaptation in these $F$. heteroclitus populations are not known, these findings are consistent with the development of rapid resistance involving few loci, which has been noted in plants (e.g., Shaw, 1999; Nacci et al., 2002b), oligochaetes 
(Martinez and Levinton, 1996), and insects (for example, McKenzie and Batterham, 1994). More generally, where the genetic mechanism of adaptation is known to be associated with few loci, the ramifications of adaptation may be predictable (Taylor and Feyereisen, 1996) and are not necessarily costly (Cousteau et al., 2000). However, a number of fitness disadvantages have been observed in $F$. heteroclitus resident in contaminated sites, including poor prey-capture capacity, reduced salinity range tolerance for egg fertilization (Bush and Weis, 1983; Weis and Khan, 1991; Smith and Weis, 1997), and increased sensitivity to low oxygen and phototoxicity (Meyer and Di Giulio, 2003). Fundulus laboratory and field populations provide opportunities to test whether these manifestations represent generalized or specific fitness trade-offs.

\subsection{Evolution of host-parasite interactions}

F. heteroclitus and related species provide an attractive model system to investigate key questions regarding the evolution and ecology of host-parasite interactions in natural populations. Long-term surveys have documented the prevalence and intensity of parasite infections in populations of $F$. heteroclitus and other estuarine Fundulus species (Harris and Vogelbein, 2006). Ecological studies in killifish include investigation of the influence of biotic and abiotic factors (e.g. salinity, streamflow) on parasite distribution and abundance (Marcogliese, 1995; Janovy et al., 1997; Janovy, 2002). Killifish have also been used as model species to investigate the impacts of parasitism on the host. The trematode worm Crassiphiala bulboglossa, a parasite with an indirect life cycle for which fish are intermediate hosts, has been shown to affect the behavior of both infected and noninfected banded killifish $F$. diaphanous (Krause and Godin, 1994). Experimental infection with C. bulboglossa negatively affected the escape response of killifish to a predator and infected F. parvipinnis exhibited behaviors which made them more susceptible to predation by the definitive avian host, such as surfacing, shimmying, and jerking (Lafferty and Morris, 1996). Non-infected killifish can detect infected killifish by the presence of black spots on the skin, and fish prefer individuals that are not parasitized (Krause et al., 1996). These observations led Krause et al. (1999) to hypothesize that trematode infection could affect shoal composition in killifish. Consistent with this hypothesis, distribution of parasites in shoals is non-random, indicating that non-parasitized fish tend to prefer shoals with non-infected fish (Krause et al., 1999). Parasitism also affected shoal behavior; parasitized fish tend to occupy the front and periphery of shoals, and shoals with parasitized fish have a different geometry than shoals with non-infected fish (Ward et al., 2002). Finally, the presence of parasites in killifish has been used to indicate the presence of definitive hosts in an area (Marcogliese and Scholz, 1999), as indicators of changes in the food web, and as bioindicators of ecosystem health (Marcogliese and Cone, 1997; Marcogliese, 2005). For example, the presence and abundance of the nematode Eustrongylides ingotus in killifish, as well as mortalities in the definitive avian host, were higher in sites with higher organic loads, probably due to increased abundance of the first intermediate oligochaete host (Spalding et al., 1993). F. heteroclitus from the heavily polluted NBH showed unusual patterns and rates of parasitism, including higher prevalence and intensity of the trematodes Ascocotyle tenuicollis and Stomachicola rubea (Cohen, 2002; Hicks and Steele, 2003; Cohen et al., 2006) as well as parasites outside their normal range of occurrence (M. Huber, M. and R. Overstreet, unpublished). Others have found that Fundulus species resident in another highly polluted site harbored fewer parasites than those from local reference (uncontaminated) sites (Bergey et al., 2002). These findings have been interpreted as evidence of pollution-related disturbance to the complex life cycle typical of many parasites. These observations also demonstrate that resident Fundulus populations provide unique and appropriate field models to test hypotheses linking direct and indirect effects of pollution to parasitism and its outcome on population persistence.

F. heteroclitus have also been used as a model to determine how selective forces such as parasite population and disease dynamics, determine and maintain diversity of the Major Histocompatibility (MH) class II genes; genes that play an important role in immune system regulation. Cohen (2002) found high levels of diversity and population-specific differences in the patterns of DNA substitution in the peptide binding site of MH class II genes in F. heteroclitus from the heavily polluted NBH (see above, Section 5.1.2) and reference sites. Consistent with the potential immunosuppressive effects of contaminants but also consistent with altered parasite abundance in this highly disturbed ecosystem, NBH $F$. heteroclitus also showed higher prevalence and intensity of parasites (Cohen, 2002; Hicks and Steele, 2003; Cohen et al., 2006). However, fish from NBH were more resistant to acute experimental infection with a bacterial pathogen, Vibrio harveyi, than fish from reference sites (D. Nacci, unpublished data). These apparently conflicting observations point to the need for a comprehensive ecological and evolutionary approach to the study of these populations, one that considers the direct and indirect effects of pollutants on both the pathogens and the fish host.

\subsection{Evolutionary variation in glycolytic enzyme expression}

One of the dominant environmental parameters affecting $F$. heteroclitus is the clinal variation in temperature along the eastern seacoast of North America. F. heteroclitus populations near the northern extreme of its distribution experience mean annual temperatures approximately $14{ }^{\circ} \mathrm{C}$ colder than southern populations. The two most important explanations for the compensatory changes are changes in the protein sequences or in the levels of expression for enzymes that affect metabolism. The primary structure for enzymes are different among populations (Place and Powers, 1978; Powers and Place, 1978; Palumbi et al., 1980; Cashon et al., 1981; Brown et al., 1988; Van Beneden and Powers, 1989; Lauerman, 1990; Ropson et al., 1990; Pierce and Crawford, 1997a). The best example of functionally important variation in protein primary structure is the heart-type lactate dehydrogenase (LDH-B) (Powers et al., 1993).

Although differences in the protein primary structure can drive biologically important changes that affect enzyme kinetics, 
much more of the difference between the northern and southern LDH-B allozymes is due to differences in gene expression. For $L d h-B$, acclimation to a $10{ }^{\circ} \mathrm{C}$ temperature decrease is associated with a 1.4 fold increase in expression (Place and Powers, 1984; Segal and Crawford, 1994; Pierce and Crawford, 1997b; Crawford et al., 1999a). Fixed differences between populations account for an additional 1.8 fold difference (Crawford and Powers, 1989; Segal and Crawford, 1994). The combination of physiologically-induced changes and evolutionary adaptive changes in gene expression explains a 2.5 -fold difference between enzyme activities among fish from northern versus southern populations at their respective native temperatures (Crawford and Powers, 1989; Segal and Crawford, 1994; Crawford et al., 1999a). The difference in expression accounts for $70 \%$ of the compensatory changes for differences in native thermal environment and the remaining $30 \%$ is due to differences in kinetic parameters, $\mathrm{pH}$ and solute concentration.

The difference in LDH-B protein concentration among populations is due to an increased rate of RNA transcription in the northern populations (Crawford and Powers, 1989, 1992). This variation in transcription of $L d h-B$ is associated with a few nucleotide changes in the proximal promoter (Segal et al., 1996, 1999; Schulte et al., 1997, 2000). These changes in DNA sequence affect transcriptional binding sites thereby altering binding affinities (Segal et al., 1999) and impacting gene expression in vitro (Segal et al., 1996, 1999; Crawford et al., 1999a). More importantly, the pattern of nucleotide variation is non-random. There are too many fixed differences between populations at regulatory sites. This non-random pattern suggests that the nucleotide changes that affect gene expression are evolving by natural selection and, thus, are biologically important.

In summary, these changes in gene expression appear to be biologically important because they compensate for the change in thermal environment, affect physiological function, and are evolving by natural selection (Powers et al., 1991; Pierce and Crawford, 1996, 1997a; Crawford et al., 1999a; Crawford et al., 1999b; Oleksiak et al., 2005).

\subsection{Evolutionary variation in messenger RNA expression}

A small but influential series of microarray studies, using a variety of analytical approaches and a variety of taxa including Fundulus species, have contributed important data toward understanding the relative influences of different evolutionary forces on regulatory evolution (recently reviewed in Whitehead and Crawford, 2006b). The Fundulus studies in particular have indicated extensive variation in gene expression both among individuals within populations and between populations, and have considered taxonomic variation in gene expression within a phylogenetic and ecological context (Oleksiak and Crawford, 2002; Oleksiak et al., 2005; Whitehead and Crawford, 2006a).

Studies of gene expression evolution using Fundulus offer several advantages over other models. First, within-population variation can be measured, whereas individuals of many other model organisms such as yeast, worms, and fruit flies are so small that it has to date been difficult or impossible to obtain sufficient RNA to quantify inter-individual variation. Upwards of $70-95 \%$ of genes in Fundulus vary significantly in mRNA concentration among individuals. Since it is generally agreed that much of the variation in gene expression is heritable (Stamatoyannopoulos, 2004; Gibson and Weir, 2005; Whitehead and Crawford, 2005, 2006a), such variation is likely to provide considerable raw material for evolution. Second, the ecological basis for genomic variation is clearer for comparisons among Fundulus taxa than for other popular comparisons such as those between humans and chimpanzees (Enard et al., 2002) or between mice and humans (Lemos et al., 2005) or among strains of fruit flies (Rifkin et al., 2003). Finally, evolutionary studies using Fundulus populations offer the advantage that this is a group of relatively closely related yet adaptively divergent taxa. That is, niche breadth and physiological tolerances vary extensively among species of the same genus, and even among populations of the same species. When comparing taxa that are more distantly related, the influence of genetic drift on trait variation becomes complex and difficult to interpret.

\subsection{Adaptive patterns of DNA variation}

Adaptive patterns of DNA variation have been detected in Fundulus. For example, polymorphisms derived through natural selection have been identified in LDH-B protein (Crawford et al., 1989; Lauerman, 1990; Powers et al., 1993), in LDH-B proximal promoter (Segal et al., 1996, 1999). Nonneutral patterns of sequence variation have been detected in transactivation region of the AHR1 transcription factor (S. Cohen, G. Yang, S.M. Tam, D. Champlin, and D. Nacci, unpublished data), and in the Mhc class II B locus (Cohen, 2002; Cohen et al., 2006). Neutral patterns of allelic distribution have been detected for several enzymes (Place and Powers, 1978; Powers and Place, 1978; Palumbi et al., 1980; Cashon et al., 1981; Brown et al., 1988; Van Beneden and Powers, 1989; Lauerman, 1990; Ropson et al., 1990; Pierce and Crawford, 1997a). These existing studies have targeted discrete candidate loci because of the specific nature of research questions being addressed, and because of lack of availability of more extensive genomic resources. This literature provides a strong foundation on which to expand the identification of adaptive variation in Fundulus given future expansion of genomic resources.

The availability of full genome sequence information has facilitated efforts to identify genomic regions that are adaptively significant in humans (Payseur et al., 2002; Kayser et al., 2003; Voight et al., 2006) and in species of agronomic importance (Vigouroux et al., 2002). Expansion of tools applicable to species beyond traditional genomic models holds promise for extending these findings in humans and crop species by establishing the ecological context within which genomes are shaped. For example, genome scans have recently been applied to identify candidate loci responsible for local adaptation among populations of the common frog and among populations of deer mice distributed across altitudinal gradients (Storz and Dubach, 2004; Bonin et al., 2006), and among ecotypes of lake whitefish (Campbell and Bernatchez, 2004). In the context of Fundulus 
species these approaches hold promise for identifying genes responsible for adaptation to diverse ecological variables such as pollutants, temperature, salinity, and oxygen. Furthermore, plasticity itself is an evolvable trait (Schlichting and Pigliucci, 1998), and due to the well-documented resilience of killifish, genomics research in this taxonomic group holds promise for yielding insights into the genomic architecture that enables physiological plasticity itself.

Genomic technologies are enabling exploration of the underpinnings of acclimation and evolutionary change, driving the emergence of a new field: environmental genomics. As applied to traditional model organisms, environmental genomics has provided some key insights as to how the genome interacts with, integrates cues from, and is changed by the environment. Genomic technologies offer the opportunity to discover not only the mechanistic basis of adaptation, but additionally may hold promise for identifying the molecular basis of fitness trade-offs. For example, upregulation of a certain signaling pathway could be necessary for chemical tolerance, whereas downregulation of the same pathway could be necessary to optimize another fitness-related trait. Though regulatory conflicts through antagonistic pleiotropy are presumed to underlie some life-history trade-offs, few studies have identified the molecular basis for such trade-offs (Bochdanovits and de Jong, 2004).

Expansion of Fundulus genomic resources to enhance the genomic toolkit and to make resources accessible to the larger research community will accelerate progress toward understanding the genomic underpinnings of adaptation to suites of toxicological and ecological stressors. Large scale genomic resources, such as a sequenced and annotated BAC library, coupled with other genomics-based tools including fine-scale genome-wide microsatellite markers and restriction-site polymorphism markers, will make it possible to conduct highresolution genome scans for environmentally-relevant genes, greatly aiding molecular evolutionary and population genetic approaches. Finally, a broader suite of genomic tools for Fundulus will provide a powerful system to investigate genetic changes occurring in wild populations subject to intense and rapidly changing environmental pressures, including a fuller understanding of the mechanistic basis of adaptation and fitness trade-offs including the role of gene expression conflicts in antagonistic pleiotropy.

\section{Fundulus genomics: current status}

The scientific community is now in a powerful position to identify and make sense of variation within and among populations by employing genomic technologies. Genomics is the field of research, or set of tools, that examines most, if not all, of the DNA, genes, proteins or other products derived from the heritable material of the cell. The two most frequently identified tools for genomics are the sequences of the nuclear genome, which is approximately 1.5 billion basepairs per haploid genome in $F$. heteroclitus, and expressed sequence tags (ESTs). ESTs represent short, 500-700 basepair sequences from mRNAs reverse-transcribed to complementary DNAs.

\subsection{ESTS}

Expressed mRNAs are much less complex than genomic DNA because they lack introns, promoters and other nontranscribed DNA and only a subset of genes are expressed in a single tissue. This simplicity allows one to more readily define the proteins expressed by a gene and provides some hints about their functions. For these reasons, isolation and sequencing of mRNAs often are used to investigate genomes.

For F. heteroclitus there is a large collection of ESTs and complete cDNAs (Paschall et al., 2004). The National Center for Biotechnology Information lists approximately 55,000 nucleotide sequences. This is about $1 / 20$ the number of ESTs as zebrafish (Table 1). These $F$. heteroclitus ESTs form approximately 18,000 unique sequences (http://compbio.dfci. harvard.edu/tgi/cgi-bin/tgi/gimain.pl?gudb=killifish). Transcript-based UniGene analysis at NCBI via staged clustering yields 3415 unigenes for this dataset (http://www.ncbi.nlm.nih. gov/UniGene/UGOrg.cgi?TAXID)=8078). Most of the Fundulus sequences are from two laboratories: Crawford \& Oleksiak at the University of Miami $(\approx 48,000)$ and Towle at Mount Desert Island Biological Laboratory $(\approx 7000)$. These ESTs represent most tissues (brain, blood, bone, eye, fat tissue, gill, gall bladder, gut, heart, intestine, kidney, liver, opercular epithelium, skeletal muscle, skin, spleen) from several populations exposed to different salinities, temperatures, hypoxia and hydrocarbons. All developmental stages and fry were also used. This diversity of tissues from fish of many populations exposed to a variety of physiological stressors should provide a broad assortment of expressed genes. The information about these ESTs includes annotations based on similarity to human, other fish and data listed in SwissProt, gene abbreviations, enzyme commission numbers, Kyoto Encyclopedia of Genes and Genomes (KEGG) metabolic pathways and Gene Ontologies (GO) (Paschall et al., 2004).

\subsection{Microarrays}

There are a number of primary research publications that have used Fundulus microarrays produced from ESTs. As documented elsewhere in this review, these publications have been used to measure individual variation in gene expression, to examine the affect of polymorphism on tissue-specific expression on cardiac physiology, to study alterations in gene expression due to toxicant exposure and to explore evolutionary and ecological processes in Fundulus species. These microarray studies require appropriate bioinformatics. There are two sources of bioinformatics for most of the 55,000 ESTs: FunnyBase http://crawford.rsmas.miami.edu/ (Paschall et al., 2004) and DFCI Killifish Gene Index http://compbio.dfci. harvard.edu/tgi/cgi-bin/tgi/gimain.pl?gudb=killifish. Using good annotation to know which genes belong to which metabolic pathway allowed the determination of the relationship between cardiac metabolism and gene expression (Oleksiak et al., 2005), demonstrated that a higher frequency of oxidative-phosphorylation genes are affected by stabilizing selection (Whitehead and Crawford, 2006a), and provided 
Table 1

EST projects among fishes

\begin{tabular}{|c|c|c|c|c|}
\hline Common name & Scientific name & $\begin{array}{l}\text { No. of ESTs } \\
(\mathrm{NCBI})\end{array}$ & $\begin{array}{l}\text { No. of ESTs } \\
\text { (other sources) }\end{array}$ & Reference \\
\hline Cichlids & Astatotilapia burtoni & 3670 & 4000 & http://hcgs.unh.edu/cichlid/\#cDNA \\
\hline Killifish & Austrofundulus limnaeus & 91 & & \\
\hline Goldfish & Carassius auratus & 2688 & & \\
\hline Common carp & Cyprinus carpio & 19,866 & & \\
\hline Zebrafish & Danio rerio & $1,364,471$ & 833,880 & http://compbio.dfci.harvard.edu/tgi/cgi-bin/tgi/gimain.pl?gudb=zfish \\
\hline Pufferfish & Takifugu rubripes & 26,115 & 25,002 & http://compbio.dfci.harvard.edu/tgi/cgi-bin/tgi/gimain.pl?gudb=fugu \\
\hline Killifish & Fundulus heteroclitus & 55,267 & 53,977 & $\begin{array}{l}\text { http://genomics.rsmas.miami.edu/funnybase/super_craw3/ } \\
\mathrm{http} / / / \text { compbio.dfci.harvard.edu/tgi/cgi-bin/tgi/gimain.pl?gudb=killifish }\end{array}$ \\
\hline Stickleback & Gasterosteus aculeatus & 277,098 & 47,693 & http://cegs.stanford.edu/stickleback_EST_sequences.jsp \\
\hline Long-jaw mudsucker & Gillichthys mirabilis & 5107 & & \\
\hline Short-jaw mudsucker & Gillichthys seta & 66 & & \\
\hline Blue catfish & Ictalurus furcatus & 10,766 & & \\
\hline Channel catfish & Ictalurus punctatus & 46,297 & 44,037 & http://compbio.dfci.harvard.edu/tgi/cgi-bin/tgi/gimain.pl?gudb=catfish \\
\hline Chum salmon & Oncorhynchus keta & 40 & & \\
\hline Rainbow trout & Oncorhynchus mykiss & 269,112 & 244,984 & http://compbio.dfci.harvard.edu/tgi/cgi-bin/tgi/gimain.pl?gudb=r_trout \\
\hline Sockeye salmon & Oncorhynchus nerka & 674 & & \\
\hline Chinook salmon & Oncorhynchus tshawytscha & 13,992 & & \\
\hline Gulf toadfish & Opsanus beta & 624 & & \\
\hline Nile tilapia & Oreochromis niloticus & 470 & & \\
\hline Japanese medaka & Oryzias latipes & 344,336 & 147,802 & http://compbio.dfci.harvard.edu/tgi/cgi-bin/tgi/gimain.pl?gudb=o_latipes \\
\hline Flounder & Platichthys flesus & 8267 & & \\
\hline Guppy & Poecilia reticulata & 14 & & \\
\hline Atlantic salmon & Salmo salar & 432,888 & 236,009 & http://compbio.dfci.harvard.edu/tgi/cgi-bin/tgi/gimain.pl?gudb=salmon \\
\hline Spotted green pufferfish & Tetraodon nigroviridis & 314,823 & & \\
\hline Swordtail & $\begin{array}{l}\text { Xiphophorus maculatus } x \\
\text { Xiphophorus helleri }\end{array}$ & 9 & & \\
\hline Cichlids (all species) & & & 63,000 & http://hcgs.unh.edu/cichlid/\#cDNA \\
\hline Total & & $2,908,861$ & & \\
\hline
\end{tabular}

insight into tissue-specific gene expression (Whitehead and Crawford, 2005).

\subsection{Genomes}

Comparative genomics, the use of genomes from diverse species, is one of the most effective methods to address the difficulties in understanding genomes. Genomics of fishes seek to provide evolutionary comparisons to better annotate genes (providing information on function), define genomic architecture and roles of genes, and develop insights into the creation of novel structures. Fish genomic sequences were used to identify many human genes, and these were used as one of the primary pieces of evidence that the vertebrate genome had 30,00040,000 genes and not 70,000-140,000 (Roest Crollius et al., 2000).

Currently, DNA sequences among ray-finned fishes include approximately 5.4 million nucleotides that code for approximately 160,000 proteins, from 13,000 taxonomic groups (National Center for Biotechnology Information, NCBI). There are 349 fish genomes in the NCBI database. Most of these are mitochondrial genomes rather than nuclear ones. Of the fish gene sequences, 164,109 are unigenes. Unigenes attempt to distill the large number of ESTs encoding the same protein to a single entry. Unigenes do reduce the number of "genes" but fail to put all appropriate sequences together. For example, there are nearly 400,000 human unigenes for the approximately 25,000 genes.
The $F$. heteroclitus genome is not currently sequenced. Although there are many nuclear markers, such as microsatellites and amplified fragment length polymorphisms (Roest Crollius et al., 2000; Adams et al., 2006; McMillan et al., 2006) and a good deal of knowledge concerning specific loci (Crawford and Powers, 1989; Bernardi et al., 1993; Crawford et al., 1999b; Karchner et al., 1999; Schulte et al., 2000; Schulte, 2001), F. heteroclitus lags behind many other vertebrate systems in the production of a genome sequence. This is currently being addressed. A BAC (bacterial artificial chromosome) library has been constructed by the Amemiya laboratory at the Benaroya Research Institute (www.benaroyaresearch.org) using high molecular weight DNA isolated from the erythrocytes of an individual $F$. heteroclitus collected in Block Island, RI, a location situated within the northern population range of $F$. heteroclitus. In general, northern populations of $F$. heteroclitus show lower genetic variation than southern populations (e.g., Powers and Place, 1978; Crawford et al., 1999a; Adams et al., 2006). The genome size of $F$. heteroclitus has been estimated at $3 \mathrm{pg}$ per diploid nucleus, based on bulk fluorometric analysis (Hinegardner, 1968; Hinegardner and Rosen, 1972), while Gómez-Chiarri and Amemiya (Gómez-Chiarri, M. and Amemiya, C., unpublished) employed flow cytometry and a chicken standard to estimate the genome size at $2.75 \mathrm{pg}$ per diploid nucleus. The library consists of more than 92,000 clones with an average insert size of $140 \mathrm{~kb}$, resulting in an estimated 10 fold coverage of the F. heteroclitus genome. The availability of this library will greatly facilitate genomic research in Fundulus species. 


\subsection{Natural and constructed genetic modifications}

As emphasized above, wild populations of Fundulus spp. provide truly unique models of genetic and genomic variation. These populations provide natural genetic variants to explore functional differences in responses to stressors such as temperature (e.g., Crawford and Powers, 1989; Schulte et al., 1997; Whitehead and Crawford, 2006a; Schulte, 2007) and chemical pollutants (Nacci et al., 2002b). In addition and despite the lack of a full genomic sequence for $F$. heteroclitus, laboratory-constructed lines are being developed to address specific research needs. Progress is being made in the development of genetically modified strains, inbred lineages, clones, mutants, small interfering RNA- and morpholino antisense-based gene knockdown and transgenics for this species. These approaches, which will be enhanced by full genome sequencing, provide powerful methods for broadly understanding the molecular biology of this species, as well as for elucidating mechanisms underlying phenomena such as adaptations to environmental stressors and modes of toxicity.

\subsubsection{Transgenics}

The first transgenic $F$. heteroclitus, developed as a model for in vivo mutagenesis research using the bacteriophage phiX174, demonstrated the feasibility of all aspects of transgenesis including successful transfer of DNA constructs via cytoplasmic injection of 1-2 cell stage embryos, genomic integration and germline transmission of a transgene (Winn et al., 1995). Most importantly, the spontaneous mutant frequencies of the mutation target gene in the transgenic $F$. heteroclitus, a measure of the balance between DNA damage and repair manifested as the accumulation of background mutations and, the measure of relative sensitivity of the target gene, were comparable to those observed in transgenic mice that carried the identical mutation target gene (Burkhart et al., 1993). Efforts are currently underway to develop a transgenic $F$. heteroclitus using the identical $\lambda L I Z$ bacteriophage shuttle vector containing the $c I I$ and lacI mutation target genes carried by the leading rodent mutation model (Kohler et al., 1991) and the $\lambda$ transgenic medaka (Winn et al., 2000). There appear to be few, if any, technological challenges unique to $F$. heteroclitus, or to fish in general, to impede generation of transgenic lineages, with the exception of a limited genomic database.

\subsubsection{Clones}

Although natural clones of $F$. heteroclitus can be obtained (Dawley, 1992), the ability to generate clonal individuals in the laboratory from specific populations of interest can provide added benefits. In ongoing studies, clonal $F$. heteroclitus have been produced using inactivation of spermatozoa by UV radiation, followed by precisely timed pressure treatment to produce a diploid gynogen or clone (R.N. Winn, unpublished data).

\subsubsection{Morpholinos}

Morpholino oligonucleotides designed to transiently block translation of specific mRNAs have proven very powerful for studying the function of specific genes during development in zebrafish and for elucidating mechanisms of chemical effects on development in this species. For example, zebrafish morpholino studies (Billiard et al., 2006) were employed to confirm that the AHR mediates the deleterious effects of certain PAHs on the developing cardiovascular system and that inhibition of CYP1A greatly enhances this effect. This synergy was first suggested by more traditional, and less conclusive, biochemical studies in $F$. heteroclitus (Wassenberg and Di Giulio, 2004a; Wassenberg and Di Giulio, 2004b). While morpholino technology recently was shown to work in F. heteroclitus (Matson, C.W., Clark, B.W., Jenny, M.J., Fleming, C.R., Hahn, M.E. and R.T. Di Giulio, R.T., unpublished data, observations with CYP1A morpholino), routine employment of this powerful technique for less well-studied genes will have to await sequence data.

\subsubsection{Targeted mutagenesis: knockout mutants}

Reverse genetics or knockout approaches are designed to assign biological function to uncharacterized genes in a genome. This efficient target-selected gene inactivation approach, demonstrated in zebrafish (Wienholds et al., 2002, 2003) and, more recently in medaka (Taniguchi et al., 2006), provides a powerful means to explore gene function by retrieving mutants with complete loss-of-function phenotype. To generate knockouts males are exposed to the potent mutagen ENU ( $N$-ethyl- $N$-nitrosourea), crossed with wild-type females, and then the induced mutations are retrieved from a large library of F1 progeny using PCR-based amplification of target genes of interest, followed by mutation discovery by dideoxy resequencing. Homozygous mutants can be generated by the F3 generation. The development of knockout mutants has promise for providing significant expansion of tools available to a broad research community as is similarly being realized in zebrafish and medaka. Further development of a Fundulus genetic database will be a key impetus to these efforts.

There appear to be few impediments to further development of new tools to improve our understanding of disease processes, adaptation, mutations, cancer, resistance to toxicant exposure and others. Clearly, the expansion of the Fundulus genomic database would facilitate the generation of new models that can provide rapid advances in key research areas in which this species has proven to be an ideal biological model.

\section{Summary}

The unique attributes of $F$. heteroclitus have provided a wealth of basic and applied insights into physiological, molecular, toxicological, ecological, evolutionary and disease processes that operate to shape diversity and resilience of natural populations. Accordingly, F. heteroclitus is an unparalleled laboratory and field model for studying physiological plasticity, and for dissecting the basis for sensitivity or tolerance to stress. This review highlights how Fundulus genomics has begun to serve research fields such as physiology, toxicology, and evolutionary genetics. Fundulus research has also contributed importantly to our understanding of estuarine and coastal ecology (see Able, 2002; Able et al., 2007; Kimball and Able, 
2007). We envision that genomic tools have enormous potential as complementary measures permitting Fundulus researchers to link responses from controlled laboratory to complex field environments across levels of biological organization from molecules to populations and communities.

On May 4-5, 2006, a group of 35 scientists came together at the Hollings Marine Laboratory in Charleston SC for a Fundulus Genomics Strategy Workshop. The goal of the workshop was to facilitate the implementation of genome-enabled technology across the many disciplines in which $F$. heteroclitus serves as a critical organism of study. The workshop participants agreed to establish the Fundulus Genomics Consortium (FGC), a collaborative network of investigators interested in enhancing the value of $F$. heteroclitus as a model organism for the study of questions in environmental biology by catalyzing the development of genomic resources. Goals of the FGC are (1) to promote the sharing of physical and virtual resources between laboratories working with Fundulus species through an interactive web site and regular meetings including workshops, (2) to work toward the analysis and annotation of the $F$. heteroclitus genome, including specific agreements to facilitate the production of tools for physical mapping, library production and sequencing, and the analysis of gene expression, and (3) to refocus research questions in Fundulus biology within the framework of functional genomics. The compilation of this review on status and opportunities for research with Fundulus species provides a starting point for this collaboration. Membership in the FGC is by open declaration of interested parties and the membership list, and communication with the FGC is maintained through a mail list serve at fundulus_genomics@whoi.edu (to subscribe, go to http://mailman.whoi.edu/mailman/listinfo/fundulus_fundulus genomics). The FGC website is being developed as a central repository for the workshop report, initiatives, links and databases of interest for the Fundulus community, and currently is located at http://fgc.uwaterloo.ca/.

In their consensus statement, the workshop participants emphasized that $F$. heteroclitus is the teleost model for understanding how individuals and populations interact with their environment. The uniqueness of $F$. heteroclitus as a model species derives from the combination of features that no other model shares, including: ease of care and breeding, moderate size, wide distribution, commercial importance (as bait species), extreme euryhalinity, tolerance of hypoxia, eurythermia, population-specific adaptation to toxicants, well understood developmental biology, physiology and molecular biology and genomics. No other teleost species currently under study has this wide a group of beneficial characteristics. Furthermore, these fish are abundant in coastal environments near human population centers and, consequently, are exposed to many of the same stresses that accompany urban development, including increased risk of exposure to pathogens and contaminants. Thus, while $F$. heteroclitus serves as a powerful teleost model for environmental effects on human health, we currently lack the full suite of genomic tools that would allow us to develop theory, models and data fully to address pressing issues about coastal environmental degradation and animal health. The community of scientists who employ F. heteroclitus as an experimental organism should, indeed must, work together if we are to ensure that genomics-based tools are developed and made available at large, for the benefit of science, the environment, and the organisms, including humans, who rely upon a robust global ecosystem.

\section{Acknowledgements}

This material is based on work supported by grants from the National Science Foundation DBI-0420504 (LJB), OCE 0308777 (DLC, RNW, BBR), BES-0553523 (AW), IBN 0236494 (BBR), IOB-0519579 (DHE), IOB-0543860 (DWT), FSML-0533189 (SC); National Institute of Health NIEHS P42-ES007381(GVC, MEH), P42-ES10356 (RTD), ES011588 (MFO); and NCRR P20 RR-016463 (DWT); Natural Sciences and Engineering Research Council of Canada Discovery (DLM, TDS, WSM) and Collaborative Research and Development Programs (DLM); NOAA/National Sea Grant NA86RG0052 (LJB), NA16RG2273 (SIK, MEH,GVC, JJS); Environmental Protection Agency U91620701 (WSB), R82902201(SC) and EPA's Office of Research and Development (DEN). Special thanks go to the National Science Foundation for workshop funding under IOB0539158 (KGB) and to the Hollings Marine Laboratory, Grice Marine Laboratory of the College of Charleston and the South Carolina Aquarium in Charleston, SC, for hosting the Fundulus Genomics Workshops in 2005 and 2006. We thank other participants in these workshops, including Tracy Andacht, Robert Chapman, John Colbourne, David Duvernell, Paul Gross, Josh Hamilton, Iris Knoebl, Paul Malchow, Jason Podrabsky, John Postlethwait, Robert Preston, Marc Salit, Joe Shaw, Rong-Lin Wang, Greg Warr and Ana Zimmerman for their ideas and comments in the development of this manuscript, and Chris Amemiya (Benaroya Research Institute) for supporting the creation of the Fundulus BAC library.

\section{References}

Able, K.W., 2002. Killifishes: family Fundulidae. In: Collette, B.B., KleinMacPhee, G. (Eds.), Bigelow and Schroeder's Fishes of the Gulf of Maine. Smithsonian Institution Press, Washington, D.C., pp. 292-297.

Able, K.W., Hagan, S.M., Kovitvongsa, K., Brown, S.A., Lamonaca, J.C., 2007. Piscivory by the mummichog (Fundulus heteroclitus): evidence from the laboratory and salt marshes. J. Exp. Mar. Biol. Ecol. 345, 26-37.

Adams, S.M., Lindmeier, J.B., Duvernell, D.D., 2006. Microsatellite analysis of the phylogeography, Pleistocene history and secondary contact hypotheses for the killifish, Fundulus heteroclitus. Mol. Ecol. 15, 1109-1123.

Allen, D.M., 1995. Thermal control of rod outer segment length and shedding in a fish, Fundulus zebrinus. Exp. Eye Res. 61, 165-171.

Armknecht, S.L., Kaattari, S.L., Van Veld, P.A., 1998. An elevated glutathione $S$-transferase in creosote-resistant mummichog (Fundulus heteroclitus). Aquat. Toxicol. 41, 1-16.

Armstrong, P.B., Child, J.S., 1965. Stages in the normal development of Fundulus heteroclitus. Biol. Bull. 128, 143-168.

Arzuaga, X., Elskus, A., 2002. Evidence for resistance to benzo $[a]$ pyrene and $3,4,3^{\prime} 4^{\prime}$-tetrachlorobiphenyl in a chronically polluted Fundulus heteroclitus population. Mar. Environ. Res. 54, 247-251.

Arzuaga, X., Calcano, W., Elskus, A., 2004. The DNA de-methylating agent 5azacytidine does not restore CYP1A induction in PCB resistant Newark Bay killifish (Fundulus heteroclitus). Mar. Environ. Res. 58, 517-520.

Arzuaga, X., Wassenberg, D.M., Di Giulio, R.T., Elskus, A., 2006. The chlorinated AHR ligand 3, 3',4, 4',5-pentachlorobiphenyl (PCB126) 
promotes reactive oxygen species (ROS) production during embryonic development in the killifish (Fundulus heteroclitus). Aquat. Toxicol. 76, $13-23$.

Atz, J.W., 1986. History of Fundulus in the laboratory. Am. Zool. 26, 111-120.

Bacanskas, L.R., Whitaker, J., Di Giulio, R.T., 2004. Oxidative stress in two populations of killifish (Fundulus heteroclitus) with differing contaminant exposure histories. Mar. Environ. Res. 58, 597-601.

Baier-Anderson, C., Anderson, R.S., Haasch, M.L., 2000. Peroxisome proliferating agents, retinoid metabolism, and macrophage activation. Mar. Environ. Res. 50, 467-467.

Barron, M.G., Carls, M.G., Heintz, R., Rice, S.D., 2004. Evaluation of fish early life-stage toxicity models of chronic embryonic exposures to complex polycyclic aromatic hydrocarbon mixtures. Toxicol. Sci. 78, 60-67.

Belknap, A.M., Solomon, K.R., MacLatchy, D.L., Dubé, M.G., Hewitt, L.M., 2006. Identification of compounds associated with testosterone depressions in fish exposed to bleached kraft pulp and paper mill chemical recovery condensates. Environ. Toxicol. Chem. 25, 2322-2333.

Bello, S., 1999. Characterization of resistance to halogenated aromatic hydrocarbons in a population of Fundulus heteroclitus from a marine Superfund site. Joint Graduate Program in Oceanography and Oceanographic Engineering. Massachusetts Institute of Technology/Woods Hole Oceanographic Institution.

Bello, S.M., Franks, D.G., Stegeman, J.J., Hahn, M.E., 2001. Acquired resistance to Ah receptor agonists in a population of Atlantic killifish (Fundulus heteroclitus) inhabiting a marine Superfund site: in vivo and in vitro studies on the inducibility of xenobiotic metabolizing enzymes. Toxicol. Sci. 60, 77-91.

Bergey, L., Weis, J.S., Weis, P., 2002. Mercury uptake by the estuarine species Palaemonetes pugio and Fundulus heteroclitus compared with their parasites, Probopyrus pandalicola and Eustrongylides sp. Mar. Pollut. Bull. 44, 1046-1050.

Bernardi, G., Sordino, P., Powers, D.A., 1993. Concordant mitochondrial and nuclear DNA phylogenies for populations of the teleost fish Fundulus heteroclitus. Proc. Natl. Acad. Sci. U. S. A. 90, 9271-9274.

Berra, E., Ginouves, A., Pouyssegur, J., 2005. The hypoxia-inducible-factor hydroxylases bring fresh air into hypoxia signalling. EMBO Rep. 7, 41-45.

Bieri, R.H., Hein, C., Huggett, R.J., Shou, P., Slone, H., Smith, C., Su, C.W., 1986. Polycyclic aromatic hydrocarbons in surface sediments from the Elizabeth River subestuary. Int. J. Environ. Anal. Chem. 26, 97-113.

Bigelow, H.B., Schroeder, W.G., 1953. Fishes of the Gulf of Maine. US Fish \& Wildlife Service.

Billiard, S.M., Timme-Laragy, A.R., Wassenberg, D.M., Cockman, C., Di Giulio, R.T., 2006. The role of the aryl hydrocarbon receptor pathway in mediating synergistic developmental toxicity of polycyclic aromatic hydrocarbons to zebrafish. Toxicol. Sci. $92,526-536$.

Binder, R.L., Stegeman, J.J., 1980. Induction of aryl hydrocarbon hydroxylase activity in embryos of an estuarine fish. Biochem. Pharmacol. 29, 949-951.

Bjerkas, E., Holst, J.C., Bjerkas, I., Ringvold, A., 2003. Osmotic cataract causes reduced vision in wild Atlantic salmon postsmolts. Dis. Aquat. Org. 55, $151-159$.

Black, D.E., Gutjahr-Gobell, R., Pruell, R.J., Bergen, B., McElroy, A.E., 1998a. Effects of a mixture of non-ortho- and mono-ortho-polychlorinated biphenyls on reproduction in Fundulus heteroclitus (Linneaus). Environ. Toxicol. Chem. 17, 1396-1404.

Black, D.E., Gutjahr-Gobell, R., Pruell, R.J., Bergen, B., Mills, L., McElroy, A.E., 1998b. Reproduction and polychlorinated biphenyls in Fundulus heteroclitus (Linneaus) from New Bedford Harbor, Massachusetts, USA. Environ. Toxicol. Chem. 17, 1405-1414.

Bochdanovits, Z., de Jong, G., 2004. Antagonistic pleiotropy for life-history traits at the gene expression level. Proc. R. Soc. Lond., B Biol. Sci. 271, S75-S78.

Boleza, K.A., Burnett, L.E., Burnett, K.G., 2001. Hypercapnic hypoxia compromises bactericidal activity of fish anterior kidney cells against opportunistic environmental pathogens. Fish Shellfish Immunol. 11, 593-610.

Bonin, A., Taberlet, P., Miaud, C., Pompanon, F., 2006. Explorative genome scan to detect candidate loci for adaptation along a gradient of altitude in the common frog (Rana temporaria). Mol. Biol. Evol. 23, 773-783.
Bosworth, C.A., Chou, C.W., Cole, R.B., Rees, B.B., 2005. Protein expression patterns in zebrafish skeletal muscle: initial characterization and the effects of hypoxic exposure. Proteomics 5, 1362-1371.

Boudreau, M., Courtenay, S.C., MacLatchy, D.L., Berube, C.H., Parrott, J.L., Van der Kraak, G.J., 2004. Utility of morphological abnormalities during early-life development of the estuarine mummichog, Fundulus heteroclitus, as an indicator of estrogenic and antiestrogenic endocrine disruption. Environ. Toxicol. Chem. 23, 415-425.

Boudreau, M., Courtenay, S.C., MacLatchy, D.L., Berube, C.H., Hewitt, H.M., Van der Kraak, G.J., 2005. Morphological abnormalities during early-life development of the estuarine mummichog, Fundulus heteroclitus, as an indicator of androgenic and anti-androgenic endocrine disruption. Aquat. Toxicol. 71, 357-369.

Bradford, C.S., Taylor, M.H., 1987. Semilunar changes in estradiol and cortisol coincident with gonadal maturation and spawning in the killifish Fundulus heteroclitus. Gen. Comp. Endocrinol. 66, 71-78.

Brown, D.C., Ropson, I.J., Powers, D.A., 1988. Biochemical genetics of Fundulus heteroclitus L. V. Inheritance of 10 biochemical loci. J. Heredity 79, 359-365.

Burgess, D.W., Marshall, W.S., Wood, C.M., 1998. Ionic transport by the opercular epithelia of freshwater acclimated tilapia (Oreochromis niloticus) and killifish (Fundulus heteroclitus). Comp. Biochem. Physiol. A 121, $155-164$.

Burkhart, J.G., Winn, R.N., Van Beneden, R.J., Malling, H.V., 1993. Spontaneous and induced mutagenesis in transgenic animals containing ФX174. Environ. Mol. Mutagen. 21 (Supple. 22), 9.

Bush, C.P., Weis, J.S., 1983. Effects of salinity on fertilization success in two populations of Fundulus heteroclitus. Biol. Bull. 164, 406-417.

Campbell, D., Bernatchez, L., 2004. Genomic scan using AFLP markers as a means to assess the role of directional selection in the divergence of sympatric whitefish ecotypes (vol 21, pg 945, 2004) Mol. Biol. Evol. 21, $1164-1164$.

Carletta, M.A., Weis, P., Weis, J.S., 2002. Development of thyroid abnormalities in mummichogs, Fundulus heteroclitus, from a polluted site. Mar. Environ. Res. 54, 601-604.

Cashon, R.E., Van Beneden, R.J., Powers, D.A., 1981. Biochemical genetics of Fundulus heteroclitus 4 . Spatial variation in gene frequencies of Idh-a Idh-B 6-Pgdh-a and Est-S. Biochem. Genet. 19, 715-728.

Cerda, J., Calman, B.G., LaFleur, G.J., Limesand, S.W., 1996. Pattern of vitellogenesis and follicle maturational competence during the ovarian follicular cycle of Fundulus heteroclitus. Gen. Comp. Endocrinol. 103, $24-35$.

Choe, K.P., Havird, J., Rose, R., Hyndman, K., Piermarini, P., Evans, D.H., 2006. COX2 in a euryhaline teleost, Fundulus heteroclitus: primary sequence, distribution, localization, and potential function in gills during salinity acclimation. J. Exp. Biol. 209, 1696-1708.

Cliff, W.H., Beyenbach, K.W., 1992. Secretory renal proximal tubules in seawater- and freshwater-adapted killifish. Am. J. Physiol. 262, F108-F116.

Cochran, R.E., Burnett, L.E., 1996. Respiratory responses of the salt marsh animals, Fundulus heteroclitus, Leiostomus xanthurus, and Palaemonetes pugio to environmental hypoxia and hypercapnia and to the organophosphate pesticide, azinphosmethyl. J. Exp. Mar. Biol. Ecol. 195, 125-144.

Cohen, S., 2002. Strong positive selection and habitat-specific amino acid substitution patterns in MHC from an estuarine fish under intense pollution stress. Mol. Biol. Evol. 19, 1870-1880.

Cohen, S., Tirindelli, J., Gomez-Chiarri, M., Nacci, D., 2006. Functional implications of major histocompatibility $(\mathrm{MH})$ variation using estuarine fish populations. Integr. Comp. Biol. 46, 1016-1029.

Cooper, P.S., Vogelbein, W., Van Veld, P.A., 1996. Immunohistochemical and immunoblot detection of p-glycoprotein in normal and neoplastic fish liver. In: Ostrander, G.K. (Ed.), Techniques in Aquatic Toxicology. CRC/Lewis Publishers, Boca Raton, FL, pp. 307-325.

Cooper, P.S., Vogelbein, W.K., Van Veld, P.A., 1999. Altered expression of the xenobiotic transporter P-glycoprotein in liver and liver tumours of mummichog (Fundulus heteroclitus) from a creosote-contaminated environment. Biomarkers 4, 48-58.

Couillard, C.M., 2002. A microscale test to measure petroleum oil toxicity to mummichog embryos. Environ. Toxicol. 17, 195-202. 
Cousteau, C., Chevillon, C., ffrench-Constant, R., 2000. Resistance to xenobiotics and parasites: can we count the costs? Trends Ecol. Evol. 15, $378-383$.

Coward, P., Lee, D., Hull, M.V., Lehmann, J.M., 2001. 4-Hydroxytamoxifen binds to and deactivates the estrogen-related receptor gamma. Proc. Natl. Acad. Sci. U. S. A. 98, 8880-8884.

Crawford, R.B., Guarino, A.M., 1976. Effects of DDT in Fundulus: studies on toxicity, fate, and reproduction. Arch. Environ. Contam. Toxicol. 4, 334-338.

Crawford, D.L., Powers, D.A., 1989. Molecular basis of evolutionary adaptation at the lactate dehydrogenase-B locus in the fish Fundulus heteroclitus. Proc. Natl. Acad. Sci. U. S. A. 86, 9365-9369.

Crawford, D.L., Powers, D.A., 1992. Evolutionary adaptation to different thermal environments via transcriptional regulation. Mol. Biol. Evol. 9, 806-813.

Crawford, D.L., Constantino, H.R., Powers, D.A., 1989. Lactate dehydrogenase-B cDNA from the teleost Fundulus heteroclitus: evolutionary implications. Mol. Biol. Evol. 6, 369-383.

Crawford, D.L., Pierce, V.A., Segal, J.A., 1999a. Evolutionary physiology of closely related taxa: analyses of enzyme expression. Am. Zool. 39, 389-400.

Crawford, D.L., Segal, J.A., Barnett, J.L., 1999b. Evolutionary analysis of TATA-less proximal promoter function. Mol. Biol. Evol. 16, 194-207.

Crisp, T.M., Clegg, E.D., Cooper, R.L., Wood, W.P., Anderson, D.G., Baetchke, K.P., Hoffmann, J.L., Morrow, M.S., Rodier, D.J., Schaeffer, J.E., Touart, L.W., Zeeman, M.G., Patel, Y.M., 1998. Environmental endocrine disruption: an effects assessment and analysis. Environ. Health Perspect. 106, 11-56.

Daborn, K., Cozzi, R.R.F., Marshall, W.S., 2001. Dynamics of pavement cellchloride cell interactions during abrupt salinity change in Fundulus heteroclitus. J. Exp. Biol. 204, 1889-1899.

Davanzo, C., Kremer, J.N., 1994. Diel oxygen dynamics and anoxic events in an eutrophic estuary of Waquoit Bay, Massachusetts. Estuaries 17, 131-139.

Dawley, R.M., 1992. Clonal hybrids of the common laboratory fish Fundulus heteroclitus. Proc. Natl. Acad. Sci. U. S. A. 89, 2485-2488.

De Montellano, P.R.O., 1995. Structure, mechanism, and inhibition of cytochrome-P450. Drug Metab. Dispos. 23, 1181-1187.

Degnan, K.J., Karnaky Jr., K.J., Zadunaisky, J., 1977. Active chloride transport in the in vitro opercular skin of a teleost (Fundulus heteroclitus), a gill-like epithelium rich in chloride cells. J. Physiol. Lond. 271, 155-191.

Delamere, N.A., Tamiya, S., 2004. Expression, regulation and function of Na,KATPase in the lens. Prog. Retin. Eye Res. 23, 593-615.

Delpire, E., Gagnon, K.B., 2006. SPAK and OSR1, key kinases involved in the regulation of chloride transport. Acta Physiol. (Oxf.) 187, 103-113.

Diaz, R.J., 2001. Overview of hypoxia around the world. J. Environ. Qual. 30, $275-281$.

Diaz, R.J., Rosenberg, R., 1995. Marine benthic hypoxia: a review of its ecological effects and the behaviourial responses of benthic macrofauna. In: Ansell, A.D., Gibson, R.N., Barnes, M. (Eds.), Oceanography and Marine Biology: An Annual Review, vol. 33. Univ. College of London Press, pp. 245-303.

DiMichele, L., Powers, D.A., 1982a. LDH-B genotype-specific hatching times of Fundulus heteroclitus embryos. Nature 296, 563-564.

DiMichele, L., Powers, D.A., 1982b. Physiological basis for swimming endurance differences between LDH-B genotypes of Fundulus heteroclitus Science 216, 1014-1016.

DiMichele, L., Powers, D.A., 1984a. Developmental and oxygen consumption rate differences between lactate dehydrogenase B genotypes of Fundulus heteroclitus and their effect on hatching time. Physiol. Zool. 57, 52-56.

DiMichele, L., Powers, D.A., 1984b. The relationship between oxygen consumption rate and hatching in Fundulus heteroclitus. Physiol. Zool. 71, $400-406$.

DiMichele, L., Powers, D.A., 1991. Allozyme variation, development rate and differential mortality in the teleost Fundulus heteroclitus. Physiol. Zool. 57, 46-51.

DiMichele, L., Westerman, M.E., 1997. Geographic variation in development rate between populations of the teleost Fundulus heteroclitus. Mar. Biol. 128, $1-7$

DiMichele, L., Paynter, K.T., Powers, D.A., 1991. Evidence of lactate dehydrogenase-B allozyme effects in the teleost, Fundulus heteroclitus. Science 253, 898-900.

Dubé, M.G., MacLatchy, D.L., 2000. Endocrine responses of Fundulus heteroclitus to effluent from a bleached-kraft pulp mill before and after installation of reverse osmosis treatment of a waste stream. Environ. Toxicol. Chem. 19, 2788-2796.

Dubé, M.G., MacLatchy, D.L., 2001. Identification and treatment of a waste stream at a bleached-kraft pulp mill that depresses a sex steroid in the mummichog (Fundulus heteroclitus). Environ. Toxicol. Chem. 20, 985-995.

Dubé, M.G., Culp, J.M., Cash, K.J., Glozier, N.E., MacLatchy, D.L., Podemski, C.L., Lowell, R.B., 2002. Artificial streams for environmental effects monitoring (EEM): development and application in Canada over the past decade. Water Qual. Res. J. Can. 37, 155-180.

Edwards, S.L., Morrison-Shetlar, A.I., Claiborne, J.B., 2002. Molecular identification of $\mathrm{Na}^{+} / \mathrm{H}^{+}$exchanger cDNA in the gills of the euryhaline mummichog (Fundulus heteroclitus). Bull. Mt Des. Is. Biol. Lab. 20, 24.

Edwards, S.L., Wall, B.P., Morrison-Shetlar, A., Sligh, S., Weakley, J.C., Claiborne, J.B., 2005. The effect of environmental hypercapnia and salinity on the expression of NHE-like isoforms in the gills of a euryhaline fish (Fundulus heteroclitus). J. Exp. Zool. A 303, 464-475.

Eisler, R., 1986. Use of Fundulus heteroclitus in pollution studies. Am. Zool. 26, $286-288$.

Elskus, A.A., Stegeman, J.J., 1989. Induced cytochrome P-450 in Fundulus heteroclitus associated with environmental contamination by polychlorinated biphenyls and polynuclear aromatic hydrocarbons. Mar. Environ. Res. 27, 31-50.

Elskus, A.A., Monosson, E., McElroy, A.E., Stegeman, J.J., Woltering, D.S., 1999. Altered CYP1A expression in Fundulus heteroclitus adults and larvae: a sign of pollutant resistance? Aquat. Toxicol. 45.

Enard, W., Khaitovich, P., Klose, J., Zoellner, S., Heissig, F., Giavalisco, P., Nieselt-Struwe, K., Muchmore, E., Varki, A., Ravid, R., Doxiadis, G.M., Bontrop, R.E., Paeaebo, S., 2002. Intra- and interspecific variation in primate gene expression patterns. Science 296, 340-343.

Endler, J.A., 1986. Natural selection in the wild. Princeton University Press, Princeton, NJ, USA.

Engle, K.B., Callard, G.V., 2007. Endrocrinology of Leydig cells in nonmammalian vertebrates, Ch. 15. In: Payne, A., Hardy, M. (Eds.), The Leydig Cell in Health and Disease. Humana Press, Totowa, NJ, pp. 207-224.

Epstein, F.H., Katz, A.I., Pickford, G.E., 1967. Sodium- and potassiumactivated adenosine triphosphatase of gills: role in adaptation of teleosts to salt water. Science 156, 1245-1247.

Eriksson, O., Mayer-Gostan, N., Wistrand, P.J., 1985. The use of isolated fish opercular epithelium as a model tissue for studying intrinsic activities of loop diuretics. Acta Physiol. Scand. 125, 55-66.

Evans, D.H., Rose, R.E., Roeser, J.M., Stidham, J.D., 2004. NaCl transport across the opercular epithelium of Fundulus heteroclitus is inhibited by an endothelin to NO, superoxide, and prostanoid signaling axis. Am. J. Physiol. 286, R560-R568.

Evans, D.H., Piermarini, P.M., Choe, K.P., 2005. The multifunctional fish gill: dominant site of gas exchange, osmoregulation, acid-base regulation, and excretion of nitrogenous waste. Physiol. Rev. 85, 97-177.

Eveloff, J., Kinne, R., Kinne-Saffran, E., Murer, H., Silva, P., Epstein, F.H., Stoff, J., Kinter, W.B., 1978. Coupled sodium and chloride transport into plasma membrane vesicles prepared from dogfish rectal gland. Pflüg. Arch. Eur. J. Physiol. 378, 87-92.

Faisal, M., Weeks, B.A., Vogelbein, W.K., Huggett, R.J., 1991. Evidence of aberration of the natural cytotoxic cell activity in Fundulus heteroclitus (Pisces: Cyprinodontidae) from the Elizabeth River, Virginia. Vet. Immunol. Immunopathol. 29, 339-351.

Fangue, N.A., Hofmeister, M., Schulte, P.M., 2006. Intraspecific variation in thermal tolerance and heat shock protein gene expression in common killifish, Fundulus heteroclitus. J. Exp. Biol. 209, 2859-2872.

Fernandez-Salguero, P., Hilbert, D.M., Rudikoff, S., Ward, J.M., Gonzalez, F.J., 1996. Aryl-hydrocarbon receptor-deficient mice are resistant to 2,3,7,8tetrachlorodibenzo- $p$-dioxin-induced toxicity. Toxicol. Appl. Pharmacol. 140, $173-179$.

Fisher, M.A., Oleksiak, M.F., 2007. Convergence and divergence in gene expression among natural populations exposed to pollution. BMC Genomics 8,108 .

Flamarique, I.N., Harosi, F.I., 2000. Photoreceptors, visual pigments, and ellipsosomes in the killifish, Fundulus heteroclitus: a microspectrophotometric and histological study. Visual Neurosci. 17, 403-420. 
Flemmer, A.W., Gimenez, I., Dowd, B.F., Darman, R.B., Forbush, B., 2002. Activation of the $\mathrm{Na}-\mathrm{K}-\mathrm{Cl}$ otransporter $\mathrm{NKCC1}$ detected with a phosphospecific antibody. J. Biol. Chem. 277, 37551-37558.

Fournie, J.W., Vogelbein, W.K., 1994. Exocrine pancreatic neoplasms in the mummichog (Fundulus heteroclitus) from a creosote-contaminated site. Toxicol. Pathol. 22, 237-247.

Fournier, M., Lacroix, A., Voccia, I., Brousseau, P., 1998. Phagocytic and metabolic activities of macrophages from mummichog naturally exposed to pulp mill effluents in the Miramichi River. Ecotoxicol. Environ. Saf. 40, 177-183

Fries, C.R., 1986. Effects of environmental stressors and immunosuppressants on immunity in Fundulus heteroclitus. Am. Zool. 26, 271-282.

Fritz, E.S., Meredith, W.H., Lotrich, V.A., 1975. Fall and winter movements and activity level of the mummichog, Fundulus heteroclitus, in a tidal creek. Chesap. Sci. 16, 211-214.

Fuller, R.C., Carleton, K.L., Fadool, J.M., Spady, T.C., Travis, J., 2004. Population variation in opsin expression in the bluefin killifish, Lucania goodei: a real-time PCR study. J. Comp. Physiol., A Sens. Neural Behav. Physiol. 190, 147-154

Fuller, R.C., Carleton, K.L., Fadool, J.M., Spady, T.C., Travis, J., 2005. Genetic and environmental variation in the visual properties of bluefin killifish, Lucania goodei. J. Evol. Biol. 18, 516-523.

Gagnon, K.B., England, R., Delpire, E., 2006. Characterization of SPAK and OSR1, regulatory kinases of the $\mathrm{Na}-\mathrm{K}-2 \mathrm{Cl}$ cotransporter. Mol. Cell. Biol. 26, 689-698.

Gaworecki, K.M., Rice, C.D., van den Hurk, P., 2004. Induction of phenol-type sulfotransferase and glucuronosyltransferase in channel catfish and mummichog. Mar. Environ. Res. 58, 525-528.

Gibson, G., Weir, B., 2005. The quantitative genetics of transcription. Trends Genet. 21, 616-623.

Godard, C.A.J., Goldstone, J.V., Said, M.R., Dickerson, R.L., Woodin, B.R., Stegeman, J.J., 2005. The new vertebrate CYP1C family: cloning of new subfamily members and phylogenetic analysis. Biochem. Biophys. Res. Commun. 331, 1016-1024.

Goldstone, H.M.H., Stegeman, J.J., 2006. A revised evolutionary history of the CYP1A subfamily: gene duplication, gene conversion, and positive selection. J. Mol. Evol. 62, 708-717.

Gonzalez, H.O., Roling, J.A., Baldwin, W.S., Bain, L.J., 2006. Physiological changes and differential gene expression in mummichogs (Fundulus heteroclitus) exposed to arsenic. Aquat. Toxicol. 77, 43-52.

Gorr, T.A., Gassmann, M., Wappner, P., 2006. Sensing and responding to hypoxia via HIF in model invertebrates. J. Insect Physiol. 52, 349-364.

Gracey, A.Y., Troll, J.V., Somero, G.N., 2001. Hypoxia-induced gene expression profiling in the euryoxic fish Gillichthys mirabilis. Proc. Natl. Acad. Sci. U. S. A. 98, 1993-1998.

Greaney, G.S., Powers, D.A., 1977. Cellular regulation of an allosteric modifier of fish haemoglobin. Nature 270, 73-74

Greaney, G.S., Powers, D.A., 1978. Allosteric modifiers of fish hemoglobins: in vitro and in vivo studies of the effect of ambient oxygen and $\mathrm{pH}$ on erythrocyte ATP concentrations. J. Exp. Zool. A 203, 339-350.

Greaney, G.S., Place, A.R., Cashon, R.E., Smith, G., Powers, D.A., 1980. Time course of changes in enzyme activities and blood respiratory properties of killifish during long-term acclimation to hypoxia. Physiol. Zool. 53, 136-144.

Greeley, M.S., Calder, D.R., Taylor, M.H., Hols, H., Wallace, R.A., 1986. Oocyte maturation in the mummichog, Fundulus heteroclitus: effects of steroids on germinal vesicle breakdown of intact follicles in vitro. Gen. Comp. Endocrinol. 62, 281-289.

Greytak, S.R., Callard, G.V., 2006. Cloning of three estrogen receptor (ER) cDNAs in killifish (Fundulus heteroclitus): differences in constitutive and inducible expression in populations from polluted (New Bedford Harbor, NBH) and unpolluted (Scorton Creek, SC) environments. ENDO 2006, vol. 1. The Endocrine Society, Boston, Massachusetts, p. 200

Greytak, S.R., Callard, G.V., 2007. Cloning of three estrogen receptors (ER) from killifish (Fundulus heteroclitus): differences in expression in populations from polluted and reference environments. Gen. Comp. Endocrinol. 150, 174-188.

Greytak, S.R., Champlin, D., Callard, G.V., 2005. Isolation and characterization of two cytochrome P450 aromatase forms in killifish (Fundulus hetero- clitus): differential expression in fish from polluted and unpolluted environments. Aquat. Toxicol. 71, 371-389.

Griffith, R.W., 1974. Environment and salinity tolerance in the genus Fundulus. Copeia 2, 319-331.

Guengerich, F.P., Liebler, D.C., 1985. Enzymatic activation of chemicals to toxic metabolites. CRC Crit. Rev. Toxicol. 14, 259-307.

Gutjahr-Gobell, R.E., Black, D.E., Mills, L.J., Pruell, R.J., Taplin, B.K., Jayaraman, S., 1999. Feeding the mummichog (Fundulus heteroclitus) a diet spiked with non-ortho- and mono-ortho-substituted polychlorinated biphenyls: accumulation and effects. Environ. Toxicol. Chem. 18, 699-707.

Haasch, M.L., 2002. Effects of vehicle, diet and gender on the expression of PMP70- and CYP2K1/2M1-like proteins in the mummichog. Mar. Environ. Res. 54, 297-301.

Hahn, M.E., 2002. Aryl hydrocarbon receptors: diversity and evolution. Chem.Biol. Interact. 141, 131-160.

Hahn, M.E., Poland, A., Glover, E., Stegeman, J.J., 1994. Photoaffinity labeling of the Ah receptor: phylogenetic survey of diverse vertebrate and invertebrate species. Arch. Biochem. Biophys. 310, 218-228.

Hahn, M.E., Karchner, S.I., Shapiro, M.A., Perera, S.A., 1997. Molecular evolution of two vertebrate aryl hydrocarbon (dioxin) receptors (AHR1 and AHR2) and the PAS family. Proc. Natl. Acad. Sci. U. S. A. 94 13743-13748.

Hahn, M.E., Karchner, S.I., Franks, D.G., 2002. Aryl hydrocarbon receptor polymorphisms and dioxin resistance in Atlantic killifish (Fundulus heteroclitus). Mar. Environ. Res. 54, 409.

Hahn, M.E., Karchner, S.I., Franks, D.G., Merson, R.R., 2004. Aryl hydrocarbon receptor polymorphisms and dioxin resistance in Atlantic killifish (Fundulus heteroclitus). Pharmacogenetics 14, 131-143.

Hahn, M.E., Karchner, S.I., Franks, D.G., Evans, B.R., Nacci, D., Champlin, D., Cohen, S., 2005. Mechanism of PCB- and dioxin-resistance in fish in the Hudson River estuary: role of receptor polymorphisms. In: H.R.F.G.A. (Ed.), Final Report (Available at http://www.hudsonriver.org/ls/).

Hahn, M.E., Karchner, S.I., Evans, B.R., Franks, D.G., Merson, R.R., Lapseritis, J.M., 2006. Unexpected diversity of aryl hydrocarbon receptors in nonmammalian vertebrates: insights from comparative genomics. J. Exp. Zool. A $305,693-706$.

Harris, C.E., Vogelbein, W.K., 2006. Parasites of mummichogs, Fundulus heteroclitus, from the York River, Virginia, U.S.A., with a checklist of parasites of Atlantic Coast Fundulus spp. Comp. Parasitol. 73, 72-110.

Hegelund, T., Celander, M.C., 2003. Hepatic versus extrahepatic expression of CYP3A30 and CYP3A56 in adult killifish (Fundulus heteroclitus). Aquat. Toxicol. 64, 277-291.

Hewitt, L.M., Smyth, S.A.M., Dubé, M.G., Gilman, C.I., MacLatchy, D.L., 2002. Isolation of compounds from bleached kraft mill recovery condensates associated with reduced levels of testosterone in mummichog (Fundulus heteroclitus). Environ. Toxicol. Chem. 21, 1359-1367.

Hewitt, L.M., Dubé, M.G., Ribey, S.C., Culp, J.M., Lowell, R.B., Hedley, K., Kilgour, B., Portt, C., MacLatchy, D.L., Munkittrick, K.R., 2005. Investigation of cause in pulp and paper environmental effects monitoring. Water Qual. Res. J. Can. 40, 261-274.

Hicks, T., Steele, E., 2003. Histological effect of Ascocotyle tenuicollis (Digenea: Heterophyidae) metacercarial infection on the heart of Fundulus heteroclitus (Teleostei: Cyprinodontidae). J. SC Acad. Sci. 1, 10-18.

Hinegardner, R., 1968. Evolution of cellular DNA content in teleost fishes. Am. Nat. 102, 517-523.

Hinegardner, R., Rosen, D.E., 1972. Cellular DNA content and the evolution of teleostean fishes. Am. Nat. 106, 621-644.

Hirota, K., Semenza, G.L., 2005. Regulation of hypoxia-inducible factor 1 by prolyl and asparaginyl hydroxylases. Biochem. Biophys. Res. Commun. 338, 610-616.

Hsiao, S.-M., Meier, A.H., 1992. Free running circasemilunar spawning rhythm of Fundulus grandis and its temperature compensation. Fish Physiol. Biochem. 10, 259-265.

Hsiao, S.-M., Greeley Jr., M.S., Wallace, R.A., 1994. Reproductive cycling in female Fundulus heteroclitus. Biol. Bull. 186, 271-284.

Hsiao, S.-M., Limesand, S.W., Wallace, R.A., 1996. Semilunar follicular cycle of an intertidal fish: the Fundulus model. Biol. Reprod. 54, 809-818.

Janovy, J., 2002. Concurrent infections and the community ecology of helminth parasites. J. Parasitol. 88, 440-445. 
Janovy, J., Snyder, S.D., Clopton, R.E., 1997. Evolutionary constraints on population structure: the parasites of Fundulus zebrinus (Pisces: Cyprinodontidae) in the South Platte river of Nebraska. J. Parasitol. 83, 584-592.

Kajimura, S., Aida, K., Duan, C.M., 2006. Understanding hypoxia-induced gene expression in early development: in vitro and in vivo analysis of hypoxiainducible factor 1-regulated zebra fish insulin-like growth factor binding protein 1 gene expression. Mol. Cell. Biol. 26, 1142-1155.

Karchner, S.I., Powell, W.H., Hahn, M.E., 1999. Identification and functional characterization of two highly divergent aryl hydrocarbon receptors (AHR1 and AHR2) in the teleost Fundulus heteroclitus. Evidence for a novel subfamily of ligand-binding basic helix-loop-helix Per-ARNT-Sim (bHLHPAS) factors. J. Biol. Chem. 274, 33814-33824.

Karchner, S.I., Franks, D.G., Powell, W.H., Hahn, M.E., 2002. Regulatory interactions among three members of the vertebrate aryl hydrocarbon receptor family: AHR repressor, AHR1, and AHR2. J. Biol. Chem. 277, 6949-6959.

Karnaky Jr., K.J., 1986. Structure and function of the chloride cell of Fundulus heteroclitus and other teleosts. Am. Zool. 26, 209-224.

Karnaky Jr., K.J., Kinter, L.B., Kinter, W.B., Stirling, C.E., 1976. Teleost chloride cell. II. Autoradiographic localization of gill Na,K-ATPase in killifish Fundulus heteroclitus adapted to low and high salinity environments. J. Cell. Biol. 70, 157-177.

Kashiwada, S., Hinton, D.E., Kullman, S.W., 2005. Functional characterization of medaka CYP3A38 and CYP3A40: kinetics and catalysis by expression in a recombinant baculovirus system. Comp. Biochem. Physiol., C, Comp. Pharmacol. Toxicol. 141, 338-348.

Katoh, F., Hyodo, S., Kaneko, T., 2003. Vacuolar-type proton pump in the basolateral plasma membrane energizes ion uptake in branchial mitochondria-rich cells of killifish Fundulus heteroclitus, adapted to a low ion environment. J. Exp. Biol. 206, 793-803.

Kayser, M., Brauer, S., Stoneking, M., 2003. A genome scan to detect candidate regions influenced by local natural selection in human populations. Mol. Biol. Evol. 20, 893-900.

Kelly-Reay, K., Weeks-Perkins, B.A., 1994. Determination of the macrophage chemiluminescent response in Fundulus heteroclitus as a function of pollution stress. Fish Shellfish Immunol. 4, 95-105.

Keys, A.B., Willmer, E.N., 1932. "Chloride-secreting cells" in the gills of fishes with special reference to the common eel. J. Physiol. Lond. 76, 368-378.

Khan, A.T., Weis, J.S., 1987a. Effect of methylmercury on egg and juvenile viability in two populations of killifish Fundulus heteroclitus. Environ. Res. $44,272-278$.

Khan, A.T., Weis, J.S., 1987b. Effects of methylmercury on sperm and egg viability of 2 populations of killifish (Fundulus heteroclitus). Arch. Environ. Contam. Toxicol. 16, 499-505.

Kimball, M.E., Able, K.W., 2007. Nekton utilization of intertidal salt marsh creeks: tidal influences in natural Spartina, invasive Phragmites, and marshes treated for Phragmites removal. J. Exp. Mar. Biol. Ecol. 346, 87-101.

Kingsolver, J.G., Hoekstra, H.E., Hoekstra, J.M., Berrigan, D., Vignieri, S.N., Hill, C.E., Hoang, C.E., Hoang, A., Gibert, P., Beerli, P., 2001. The strength of phenotypic selection in natural populations. Am. Nat. 157, 245-261.

Kloepper-Sams, P.J., Stegeman, J.J., 1989. The temporal relationships between $\mathrm{P} 450 \mathrm{E}$ protein content, catalytic activity, and mRNA levels in the teleost Fundulus heteroclitus following treatment with $\beta$-naphthoflavone. Arch. Biochem. Biophys. 268, 525-535.

Kloepper-Sams, P.J., Stegeman, J.J., 1992. Effects of temperature-acclimation on the expression of hepatic cytochrome-P4501a messenger RNA and protein in the fish Fundulus heteroclitus. Arch. Biochem. Biophys. 299, $38-46$.

Kohler, S.W., Provost, G.S., Fieck, A., Kretz, P.L., Bullock, W.O., Putman, D.L., Sorge, J.A., Short, J.M., 1991. Analysis of spontaneous and induced mutations in transgenic mice using a lambda-Zap ${ }^{\circledR} /$ lacl shuttle vector. Environ. Mol. Mutagen. 18, 316-321.

Kraemer, L.D., Schulte, P.M., 2004. Prior PCB exposure suppresses hypoxiainduced up-regulation of glycolytic enzymes in Fundulus heteroclitus. Comp. Biochem. Physiol. C, Comp. Pharmacol. Toxicol. 139, 23-29.

Krause, J., Godin, J.G., 1994. The influence of parasitism on the shoaling behavior of the killifish (Fundulus diaphanus). Can. J. Zool. 72, 1775-1779.
Krause, J., Godin, J.G., Brown, D., 1996. Phenotypic variability within and between fish shoals. Ecology 77, 1586-1591.

Krause, J., Ruxton, G.D., Godin, J.G.J., 1999. Distribution of Crassiphiala bulboglossa, a parasitic worm, in shoaling fish. J. Anim. Ecol 68, 27-33.

Kültz, D., Chakravarty, D., Adilakshmi, T., 2001. A novel 14-3-3 gene is osmoregulated in gill epithelium of the euryhaline teleost Fundulus heteroclitus. J. Exp. Biol. 204, 2975-2985.

Lafferty, K.D., Morris, A.K., 1996. Altered behavior of parasitized killifish increases susceptibility to predation by bird final hosts. Ecology 77, $1390-1397$.

Lai, J.C.C., Kakuta, I., Mok, H.O.L., Rummer, J.L., Randall, D., 2006. Effects of moderate and substantial hypoxia on erythropoietin levels in rainbow trout kidney and spleen. J. Exp. Biol. 209, 2734-2738.

Lake, J.L., McKinney, R., Lake, C.A., Osterman, F.A., Heltshe, J., 1995. Comparisons of patterns of polychlorinated biphenyl congeners in water, sediment, and indigenous organisms from New Bedford Harbor, Massachusetts. Arch. Environ. Contam. Toxicol. 29, 207-220.

Landry, C.A., Steele, S.L., Manning, S., Cheek, A.O., 2007. Chronic hypoxia suppresses reproductive capacity in the estuarine fish, Fundulus grandis. Comp. Biochem. Physiol. A 148, 317-323.

Lauerman, T., 1990. The functional significance of the amino acid differences between allelic isozymes of heart type lactate dehydrogenase in Fundulus heteroclitus. Department of Biology, Ph.D. Johns Hopkins University, Baltimore, MD

Laurent, P., Chevalier, C., Wood, C.M., 2006. Appearance of cubiodal cells in relation to salinity in gills of Fundulus heteroclitus, a species exhibiting branchial $\mathrm{Na}^{+}$but not $\mathrm{Cl}^{-}$uptake in freshwater. Cell Tissue Res. 325, 481-492.

Law, S.H.W., Wu, R.S.S., Ng, P.K.S., Yu, R.M.K., Kong, R.Y.C., 2006. Cloning and expression analysis of two distinct HIF-alpha isoforms- gcHIF-1alpha and gcHIF-4alpha- from the hypoxia-tolerant grass carp, Ctenopharyngodon idellus. BMC Mol. Biol. 7.

LeBlanc, G.A., Bain, L.J., 1997. Chronic toxicity of environmental contaminants: sentinels and biomarkers. Environ. Health Perspect. 105 (Suppl 1), $65-80$.

LeBlanc, J., Couillard, C.M., Brethes, J.-C.M., 1997. Modifications of the reproductive period in mummichog (Fundulus heteroclitus) living downstream from a bleached kraft pulp mill in the Miramichi estuary, New Brunswick, Canada. Can. J. Fish. Aquat. Sci. 54, 2564-2573.

Lee, D.S., Gilbert, C.R., Hocutt, V.H., Jenkins, R.E., McAllister, D.C., Stauffer, J.R., 1980. Atlas of North American Freshwater Fishes. In: N.C.B. (Ed.), Survey, vol. Publication \#1980-12. North Carolina State Museum of Natural History.

Lemos, B., Meiklejohn, C.D., Caceres, M., Hartl, D.L., 2005. Rates of divergence in gene expression profiles of primates, mice and flies: stabilizing selection and variability among functional categories. Evolution $59,126-137$.

Lima, R.N., Kültz, D., 2004. Laser scanning cytometry and tissue microarray analysis of salinity effects on killifish chloride cells. J. Exp. Biol. 207, $1729-1739$

Lin, H., Pfeiffer, D.C., Vogl, A.W., Pan, J., Randall, D.J., 1994. Immunolocalization of $\mathrm{H}^{+}$-ATPase in the gill epithelia of rainbow trout. J. Exp. Biol. 195, 169-183.

Lin, Y.-W.P., LaMarca, M.J., Wallace, R.A., 1987. Fundulus heteroclitus gonadotropin(s) I. Homologous bioassay using oocyte maturation and steroid production by isolated ovarian follicles. Gen. Comp. Endocrinol. 67, $126-141$.

Lotrich, V.A., 1975. Summer home range and movements of Fundulus heteroclitus (Pisces: Cyprinodontidae) in a tidal creek. Ecology 56, 191-198.

Love, J.W., Rees, B.B., 2002. Seasonal differences in hypoxia tolerance in gulf killifish, Fundulus grandis (Fundulidae). Environ. Biol. Fish. 63, 103-115.

MacLatchy, D.L., Courtenay, S.C., Rice, C.D., Van der Kraak, G.J., 2003. Development of a short-term reproductive endocrine bioassay using steroid hormone and vitellogenin end points in the estuarine mummichog (Fundulus heteroclitus). Environ. Toxicol. Chem. 22, 996-1008.

Maglich, J.M., Caravella, J.A., Lambert, M.H., Willson, T.M., Moore, J.T., Ramamurthy, L., 2003. The first completed genome sequence from a teleost 
fish (Fugu rubripes) adds significant diversity to the nuclear receptor superfamily. Nucleic Acids Res. 31, 4051-4058.

Malvin, R.L., Schiff, D., Eiger, S., 1980. Angiotensin and drinking rates in the euryhaline killifish. Am. J. Physiol. 239, R31-R34.

Mancera, J.M., McCormick, S.D., 2000. Rapid activation of gill $\mathrm{Na}^{+}, \mathrm{K}^{+}$-ATPase in the euryhaline teleost Fundulus heteroclitus. J. Exp. Zool. 287, 263-274.

Maples, N.L., Bain, L.J., 2004. Trivalent chromium alters gene expression in the mummichog (Fundulus heteroclitus). Environ. Toxicol. Chem. 23, 626-631.

Marcogliese, D.J., 1995. Comparison of parasites of mummichogs and sticklebacks from brackish and freshwater ponds on Sable Island, Nova Scotia. Am. Midl. Nat. 133, 333-343.

Marcogliese, D.J., 2005. Parasites of the superorganism: are they indicators of ecosystem health? Int. J. Parasitol. 35, 705-716.

Marcogliese, D.J., Cone, D.K., 1997. Food webs: a plea for parasites. Trends Ecol. Evol. 12, 320-325.

Marcogliese, D.J., Scholz, T., 1999. Recent visitations by eels to Sable Island, Canada, confirmed by parasites. J. Fish Biol. 54, 685-687.

Marshall, W.S., 2002. $\mathrm{Na}^{+}, \mathrm{Cl}^{-}, \mathrm{Ca}^{2+}$ and $\mathrm{Zn}^{2+}$ transport by fish gills: retrospective review and prospective synthesis. J. Exp. Zool. 293, 264-283.

Marshall, W.S., Grosell, M., 2005. Ion transport, osmoregulation and acid-base balance. In: Evans, D.H., Clairborne, J.B. (Eds.), The Physiology of Fishes. CRC Press, Boca Raton, pp. 177-230.

Marshall, W.S., Bryson, S.E., Garg, D., 1993. Alpha 2-adrenergic inhibition of $\mathrm{Cl}^{-}$transport by opercular epithelium is mediated by intracellular $\mathrm{Ca}^{2+}$ Proc. Natl. Acad. Sci. U. S. A. 90, 5504-5508.

Marshall, W.S., Bryson, S.E., Darling, P., Whitten, C., Patrick, M., Wilkie, M., Wood, C.M., Buckland-Nicks, J., 1997. $\mathrm{NaCl}$ transport and ultrastructure of opercular epithelium from a freshwater-adapted euryhaline teleost, Fundulus heteroclitus. J. Exp. Zool. A 277, 23-37.

Marshall, W.S., Emberley, T.R., Singer, T.D., Bryson, S.E., McCormick, S.D., 1999. Time course of salinity adaptation in a strongly euryhaline estuarine teleost, Fundulus heteroclitus: a multivariable approach. J. Exp. Biol. 202, $1535-1544$.

Marshall, W.S., Lynch, E.M., Cozzi, R.R., 2002. Redistribution of immunofluorescence of CFTR anion channel and NKCC cotransporter in chloride cells during adaptation of the killifish Fundulus heteroclitus to sea water. J. Exp. Biol. 205, 1265-1273.

Marshall, W.S., Cozzi, R.R., Pelis, R.M., McCormick, S.D., 2005. Cortisol receptor blockade and seawater adaptation in the euryhaline teleost Fundulus heteroclitus. J. Exp. Zool. A 303, 132-142.

Martinez, D.E., Levinton, J., 1996. Adaptation to heavy metals in the aquatic oligochaete Limnodrilus hoffmeisteri: evidence for control by one gene. Evolution 50, 1339-1343.

Martinez, M.L., Landry, C.A., Boehm, R., Manning, S., Cheek, A.O., Rees, B.B., 2006. Effects of long-term hypoxia on enzymes of carbohydrate metabolism in the Gulf killifish, Fundulus grandis. J. Exp. Biol. 209, 3851-3861.

Matta, M.B., Linse, J., Cairncross, C., Francendese, L., Kocan, R.M., 2001. Reproductive and transgenerational effects of methylmercury or Aroclor 1268 on Fundulus heteroclitus. Environ. Toxicol. Chem. 20, 327-335.

McArdle, M.E., McElroy, A.E., Elskus, A.A., 2004. Enzymatic and estrogenic responses to fish exposed to organic pollutants in the New York-New Jersey (USA) Harbor Complex. Environ. Toxicol. Chem. 23, 953-959.

McKenzie, J.A., Batterham, P., 1994. The genetic, molecular and phenotypic consequences of selection for insecticide resistance. Trends Ecol. Evol. 9, $166-169$

McMillan, A.M., Bagley, M.J., Jackson, S.A., Nacci, D.E., 2006. Genetic diversity and structure of an estuarine fish (Fundulus heteroclitus) indigenous to sites associated with a highly contaminated urban harbor. Ecotoxicology 15, 539-548.

Meyer, A., Lydeard, C., 1993. The evolution of copulatory organs, internal fertilization, placentae, and viviparity in killifishes (Cyprinodontiformes) inferred from a DNA phylogeny of the tyrosine kinase gene X-src. Proc. Biol. Sci. 254, 153-162.

Meyer, J., Di Giulio, R.T., 2002. Patterns of heritability of decreased EROD activity and resistance to PCB 126-induced teratogenesis in laboratoryreared offspring of killifish (Fundulus heteroclitus) from a creosote- contaminated site in the Elizabeth River, VA, USA. Mar. Environ. Res. $54,621-626$.

Meyer, J.N., Di Giulio, R.T., 2003. Heritable adaptation and fitness costs in killifish (Fundulus beteroclitus) inhabiting a polluted estuary. Ecol. Appl. 13, 490-503.

Meyer, J.N., Nacci, D.E., Di Giulio, R.T., 2002. Cytochrome P4501A (CYP1A) in killifish (Fundulus heteroclitus): heritability of altered expression and relationship to survival in contaminated sediments. Toxicol. Sci. 68, 69-81.

Meyer, J.N., Smith, J.D., Winston, G.W., Di Giulio, R.T., 2003. Antioxidant defenses in killifish (Fundulus heteroclitus) exposed to contaminated sediments and model prooxidants: short-term and heritable responses. Aquat. Toxicol. 65, 377-395.

Meyer, J.N., Volz, D.C., Freedman, J.H., Di Giulio, R.T., 2005. Differential display of hepatic mRNA from killifish (Fundulus heteroclitus) inhabiting a Superfund estuary. Aquat. Toxicol. 73, 327-341.

Monteverdi, G.H., Di Giulio, R.T., 2000. Vitellogenin association and oocytic accumulation of thyroxine and 3, 5, 3'-triiodothyronine in gravid Fundulus heteroclitus. Gen. Comp. Endocrinol. 120, 198-211.

Moore, L.B., Maglich, J.M., McKee, D.D., Wisely, B., Willson, T.M., Kliewer, S.A., Lambert, M.H., Moore, J.T., 2002. Pregnane X receptor (PXR), constitutive androstane receptor (CAR), and benzoate $\mathrm{X}$ receptor (BXR) define three pharmacologically distinct classes of nuclear receptors. Mol. Endocrinol. 16, 977-986.

Moseley, A., Graw, J., Delamere, N.A., 2002. Altered Na,K-ATPase pattern in gamma-crystallin mutant mice. Invest. Ophth. Vis. Sci. 43, 1517-1519.

Mulvey, M., Newman, M.C., Vogelbein, W., Unger, M.A., 2002. Genetic structure of Fundulus heteroclitus from PAH-contaminated and neighboring sites in the Elizabeth and York Rivers. Aquat. Toxicol. 61, 195-209.

Mulvey, M., Newman, M.C., Vogelbein, W.K., Unger, M.A., Ownby, D.R., 2003. Genetic structure and mtDNA diversity of Fundulus heteroclitus populations from polycyclic aromatic hydrocarbon-contaminated sites. Environ. Toxicol. Chem. 22, 671-677.

Nacci, D., Coiro, L., Kuhn, A., Champlin, D., Munns, W., Specker, J., Cooper, K., 1998. Nondestructive indicator of ethoxyresorufin- $O$-deethylase activity in embryonic fish. Environ. Toxicol. Chem. 17, 2481-2486.

Nacci, D., Coiro, L., Champlin, D., Jayaraman, S., McKinney, R., Gleason, T.R., Munns, W.R., Specker, J.L., Cooper, K.R., 1999. Adaptations of wild populations of the estuarine fish Fundulus heteroclitus to persistent environmental contaminants. Mar. Biol. 134, 9-17.

Nacci, D., Jayaraman, S., Specker, J., 2001. Stored retinoids in populations of an estuarine fish, Fundulus heteroclitus, indigenous to highly PCB-contaminated and reference sites. Arch. Environ. Contam. Toxicol. 40, 511-518.

Nacci, D., Gleason, T., Gutjahr-Gobell, R., Huber, M., Munns, W.R.J., 2002a. Effects of environmental stressors on wildlife populations. In: Newman, M.C. (Ed.), Coastal and Estuarine Risk Assessment: Risk on the Edge. CRC Press/Lewis Publishers, Washington, DC.

Nacci, D.E., Champlin, D., Coiro, L., McKinney, R., Jayaraman, S., 2002b. Predicting the occurrence of genetic adaptation to dioxinlike compounds in populations of the estuarine fish Fundulus heteroclitus. Environ. Toxicol. Chem. 21, 1525-1532.

Nacci, D.E., Kohan, M., Pelletier, M., George, E., 2002c. Effects of benzo[a] pyrene exposure on a fish population resistant to the toxic effects of dioxinlike compounds. Aquat. Toxicol. 57, 203-215.

Nacci, D., Coiro, L., Wasserman, D., Di Giulio, R.T., 2005. A non-destructive technique to measure cytochrome p4501A enzyme activity in living embryos of the estuarine fish Fundulus heteroclitus. In: Ostrander, G.K. (Ed.), Techniques in Aquatic Toxicology, vol. 2. Taylor and Francis Publishers, Boca Raton, FL, pp. 209-225.

Nacci, D., Walters, S., Gleason, T., Munns, W.R., Jr., in press. Using a spatial modeling approach to explore ecological factors relevant to the persistence of estuarine fish (Fundulus heterclitus) in a PCB-contaminated estuary. In: Akcakaya, H.R., Stark, J.D., Bridges, T.S. (Eds.), Demographic Toxicity: Methods in Ecological Risk Assessment. Oxford University Press, New York, NY,

Nebert, D.W., Russell, D.W., 2002. Clinical importance of the cytochromes P450. Lancet 360, 1155-1162.

Nelson, D.R., 2003. Comparison of P450s from human and fugu: 420 million years of vertebrate P450 evolution. Arch. Biochem. Biophys. 409, 18-24. 
Nelson, W.G., Bergen, B.J., Benyi, S.J., Morison, G., Voyer, R.A., Strobel, C.J., Rego, S., Thursby, G., Pesch, E., 1996. New Bedford Harbor long-term monitoring assessment report: baseline sampling. In: U.E.P.A.N.H.a.E.E.R. (Ed.), Laboratory. Atlantic Ecology Division, Narragansett, Rhode Island, USA (EPA/600/R-96/097).

Nevid, N.J., Meier, A.H., 1995. Timed daily administrations of hormones and antagonists of neuroendocrine receptors alter day-night rhythms of allograft rejection in the Gulf killifish, Fundulus grandis Gen. Comp. Endocrinol. 97, $327-339$.

Nikinmaa, M., Rees, B.B., 2005. Oxygen-dependent gene expression in fishes. Am. J. Physiol. 288, R1079-R1090.

Oleksiak, M.F., Crawford, D.L., 2002. $5^{\prime}$ genomic structure of human Sp3. Mol. Biol. Evol. 19, 2026-2029.

Oleksiak, M.F., Wu, S., Parker, C., Karchner, S.I., Stegeman, J.J., Zeldin, D.C., 2000. Identification, functional characterization, and regulation of a new cytochrome P450 subfamily, the CYP2Ns. J. Biol. Chem. 275, 2312-2321.

Oleksiak, M.F., Wu, S., Parker, C., Qu, W., Cox, R., Zeldin, D.C., Stegeman, J.J., 2003. Identification and regulation of a new vertebrate cytochrome P450 subfamily, the CYP2Ps, and functional characterization of CYP2P3, a conserved arachidonic acid epoxygenase/19-hydroxylase. Arch. Biochem. Biophys. 411, 223-234.

Oleksiak, M.F., Roach, J.L., Crawford, D.L., 2005. Natural variation in cardiac metabolism and gene expression in Fundulus heteroclitus. Nat. Genet. 37, $67-72$.

Omura, Y., Ali, M.A., 1981. Ultrastructure of the pineal organ of the killifish, Fundulus heteroclitus, with special reference to the secretory function. Cell Tissue Res. 219, 355-369.

Ownby, D.R., Newman, M.C., Mulvey, M., Vogelbein, W.K., Unger, M.A., Arzayus, L.F., 2002. Fish (Fundulus heteroclitus) populations with different exposure histories differ in tolerance of creosote-contaminated sediments. Environ. Toxicol. Chem. 21, 1897-1902.

Padma, T.V., Hale, R.C., Roberts, M.H., 1998. Toxicity of water-soluble fractions derived from whole creosote and creosote-contaminated sediments. Environ. Toxicol. Chem. 17, 1606-1610.

Pait, A.S., Nelson, J.O., 2003. Vitellogenesis in male Fundulus heteroclitus (killifish) induced by selected estrogenic compounds. Aquat. Toxicol. 64, $331-342$.

Palumbi, S.R., Sidell, B.D., Van, B.R., Smith, G.D., Powers, D.A., 1980. Glucosephosphate isomerase of the teleost Fundulus heteroclitus: isozymes, allozymes and their physiological roles. J. Comp. Physiol. 138, 49-58.

Paschall, J.E., Oleksiak, M.F., VanWye, J.D., Roach, J.L., Whitehead, J.A., Wyckoff, G.J., Kolell, K.J., Crawford, D.L., 2004. FunnyBase: a systems level functional annotation of Fundulus ESTs for the analysis of gene expression. BMC Genomics 5, 96.

Patel, M.R., Scheffler, B.E., Wang, L., Willett, K.L., 2006. Effects of benzo(a) pyrene exposure on killifish (Fundulus heteroclitus) aromatase activities and mRNA. Aquat. Toxicol. 77, 267-278.

Patrick, M.L., Wood, C.M., 1999. Ion and acid-base regulation in the freshwater mummichog (Fundulus heteroclitus): a departure from the standard model for freshwater teleosts. Comp. Biochem. Physiol. A 122, 445-456

Patrick, M.L., Pärt, P., Marshall, W.S., Wood, C.M., 1997. Characterization of ion and acid-base transport in the fresh water adapted mummichog (Fundulus heteroclitus). J. Exp. Zool. A 279, 208-219.

Paynter, K.T., DiMichele, L., Hand, S.C., Powers, D.A., 1991. Metabolic implications of LDH-B genotype during early development in Fundulus heteroclitus. J. Exp. Zool. A 257, 24-33.

Payseur, B.A., Cutter, A.D., Nachman, M.W., 2002. Searching for evidence of positive selection in the human genome using patterns of microsatellite variability. Mol. Biol. Evol. 19, 1143-1153.

Perry, D.M., Weis, J.S., Weis, P., 1988. Cytogenetic effects of methylmercury in embryos of the killifish, Fundulus heteroclitus. Arch. Environ. Contam. Toxicol. 17, 569-574

Peterson, J.S.K., Bain, L.J., 2004. Differential gene expression in anthraceneexposed mummichogs (Fundulus heteroclitus). Aquat. Toxicol. 66, 345-355.

Petrino, T.R., Lin, Y.-W.P., Wallace, R.A., 1989. Steroidogenesis in Fundulus heteroclitus I. Production of 17alpha-hydroxy, 20beta-dihydroprogesterone, testosterone, and 17beta-estradiol by prematurational follicles in vitro. Gen. Comp. Endocrinol. 73, 147-156.
Petrino, T.R., Lin, Y.-W.P., Wallace, R.A., 1993. Steroidogenesis in Fundulus heteroclitus V. Purification, characterization, and metabolism of $17 \alpha, 20 \beta-$ dihydroxy-4-pregnen-3-one by intact follicles and its role in oocyte maturation. Gen. Comp. Endocrinol. 92, 1-15.

Phillips, B., Harrison, P., 1999. Overview of the endocrine disruptor issue. In: Hester, R.E., Harrison, R.M. (Eds.), Endocrine Disrupting Chemicals, vol. 12. Royal Society of Chemistry, Cambridge, UK, pp. 1-27.

Philpott, C.W., Copeland, D.E., 1963. Fine structure of chloride cells from three species of Fundulus. J. Cell. Biol. 18, 389-404.

Pierce, V.A., Crawford, D.L., 1994. Rapid enzyme assays investigating the variation in the glycolytic pathway in field-caught populations of Fundulus heteroclitus. Biochem. Genet. 32, 315-330.

Pierce, V.A., Crawford, D.L., 1996. Variation in the glycolytic pathway: the role of evolutionary and physiological processes. Physiol. Zool. 69, 489-508.

Pierce, V.A., Crawford, D.L., 1997a. Phylogenetic analysis of glycolytic enzyme expression. Science 276, 256-259.

Pierce, V.A., Crawford, D.L., 1997b. Phylogenetic analysis of thermal acclimation of the glycolytic enzymes in the genus Fundulus. Physiol. Zool. 70, 597-609.

Place, A.R., Powers, D.A., 1978. Genetic bases for protein polymorphism in Fundulus heteroclitus (L.).I. Lactate dehydrogenase (LDH-B), malate dehydrogenase (MDH-A), glucosephosphate isomerase (GPI-B), and phosphoglucomutase (PGM-A). Biochem. Genet. 16, 577-591.

Place, A.R., Powers, D.A., 1979. Genetic variation and relative catalytic efficiencies: lactate dehydrogenase B allozymes of Fundulus heteroclitus. Proc. Natl. Acad. Sci. U. S. A. 76, 2354-2358.

Place, A.R., Powers, D.A., 1984. Kinetic characterization of the lactate dehydrogenase (LDH-B4) allozymes of Fundulus heteroclitus. J. Biol. Chem. 259, 1309-1318.

Podrabsky, J.E., Javillonar, C., Hand, S.C., Crawford, D.L., 2000. Intraspecific variation in aerobic metabolism and glycolytic enzyme expression in heart ventricles. Am. J. Physiol. 279, R2344-R2348.

Powell, W.H., Hahn, M.E., 2002. Identification and functional characterization of hypoxia-inducible factor 2alpha from the estuarine teleost, Fundulus heteroclitus: interaction of HIF-2alpha with two ARNT2 splice variants. J. Exp. Zool. A 294, 17-29.

Powell, W.H., Karchner, S.I., Bright, R., Hahn, M.E., 1999. Functional diversity of vertebrate ARNT proteins: identification of ARNT2 as the predominant form of ARNT in the marine teleost, Fundulus heteroclitus. Arch. Biochem. Biophys. 361, 156-163.

Powell, W.H., Bright, R., Bello, S.M., Hahn, M.E., 2000. Developmental and tissue-specific expression of AHR1, AHR2, and ARNT2 in dioxin-sensitive and -resistant populations of the marine fish Fundulus heteroclitus. Toxicol. Sci. 57, 229-239.

Powell, W.H., Evans, B.R., Hahn, M.E., 2002. Interactive effects of hypoxia and 2,3,7,8-tetrachlorodibenzo- $p$-dioxin (TCDD) during development in Fundulus heteroclitus. Mar. Environ. Res. 54, 304-305.

Powers, D.A., Place, A.R., 1978. Biochemical genetics of Fundulus heterolitus (L.). I. Temporal and spatial variation in gene frequencies of LDH-B, MDHA, GPI-B, and PGM-A. Biochem. Genet. 16, 593-607.

Powers, D.A., Greaney, G.S., Place, A.R., 1979. Physiological correlation between lactate dehydrogenase genotype and haemoglobin function in killifish. Nature 277, 240-241.

Powers, D.A., Lauerman, T., Crawford, D., DiMichele, L., 1991. Genetic mechanisms for adapting to a changing environment. In: Campbell, A., Baker, B.S., Jones, E.W. (Eds.), Annual Review of Genetics, vol. 25. Annual Reviews, Inc., Palo Alto, CA, pp. 629-659.

Powers, D.A., Smith, M., Gonzalez-Villasenor, I., DiMichelle, L., Crawford, D.L., Bernardi, G., Lauerman, T., 1993. A multidisciplinary approach to the selectionist/neutralist controversy using the model teleost, Fundulus heteroclitus. In: Futuyma, D., Antonovics, J. (Eds.), Oxford Surveys in Evolutionary Biology, vol. 9. Oxford University Press, New York, NY, pp. 43-108.

Prasch, A.L., Teraoka, H., Carney, S.A., Dong, W., Hiraga, T., Stegeman, J.J., Heideman, W., Peterson, R.E., 2003. Aryl hydrocarbon receptor 2 mediates 2,3,7,8-tetrachlorodibenzo- $p$-dioxin developmental toxicity in zebrafish. Toxicol. Sci. 76, 138-150.

Prasch, A.L., Andreasen, E.A., Peterson, R.E., Heideman, W., 2004. Interactions between 2,3,7,8-tetrachlorodibenzo-p-dioxin (TCDD) and hypoxia 
signaling pathways in zebrafish: hypoxia decreases responses to TCDD in zebrafish embryos. Toxicol. Sci. 78, 68-77.

Preston, R.L., Flowers, A.E., Lahey, B.C., McBride, S.R., Petersen, C.W., Kidder, G.W., 2006. Measurement of the dessication of Fundulus heteroclitus embryos in controlled humidities. Bull. Mt Des. Is. Biol. Lab. 45, 101-103.

Prince, R., Cooper, K.R., 1995a. Comparisons of the effects of 2,3,7,8tetrachlorodibenzo- $p$-dioxin on chemically impacted and nonimpacted subpopulations of Fundulus heteroclitus 1: TCDD toxicity. Environ. Toxicol. Chem. 14, 579-587.

Prince, R., Cooper, K.R., 1995b. Comparisons of the effects of 2,3,7,8tetrachlorodibenzo- $p$-dioxin on chemically impacted and nonimpacted subpopulations of Fundulus heteroclitus. 2. Metabolic considerations. Environ. Toxicol. Chem. 14, 589-595.

Pruell, R.J., Norwood, C.B., Bowen, R.D., Boothman, W.S., Rogerson, P.F., Hackett, M., Butterworth, B.C., 1990. Geochemical study of sediment contamination in New Bedford Harbor, Massachusetts. Mar. Environ. Res. $29,77-101$.

Quattro, J.M., Woods, H.A., Powers, D.A., 1993. Sequence analysis of teleost retina-specific lactate dehydrogenase-C: evolutionary implications for the vertebrate lactate dehydrogenase gene family. Proc. Natl. Acad. Sci. U. S. A. 90, 242-246.

Rees, B.B., Bowman, J.A., Schulte, P.M., 2001. Structure and sequence conservation of a putative hypoxia response element in the lactate dehydrogenase-B gene of Fundulus. Biol. Bull. 200, 247-251.

Rice, C.D., Xiang, Y., 2000. Immune function, hepatic CYP1A, and reproductive biomarker responses in the gulf killifish, Fundulus grandis, during dietary exposures to endocrine disruptors. Mar. Environ. Res. 50, $163-168$

Rifkin, S.A., Kim, J., White, K.P., 2003. Evolution of gene expression in the Drosophila melanogaster subgroup. Nat. Genet. 33, 138-144.

Roark, S.A., Nacci, D., Coiro, L., Champlin, D., Guttman, S.I., 2005. Population genetic structure of a nonmigratory estuarine fish (Fundulus heteroclitus) across a strong gradient of polychlorinated biphenyl contamination. Environ. Toxicol. Chem. 24, 717-725.

Roest Crollius, H., Jaillon, O., Bernot, A., Dasilva, C., Bouneau, L., Fischer, C., Fizames, C., Wincker, P., Brottier, P., Quetier, F., Saurin, W., Weissenbach, J., 2000. Estimate of human gene number provided by genome-wide analysis using Tetraodon nigroviridis DNA sequence. Nat. Genet. 25, 235-238.

Roling, J.A., Baldwin, W.S., 2006. Alterations in hepatic gene expression by trivalent chromium in Fundulus heteroclitus. Mar. Environ. Res. 62, S122-S127.

Roling, J.A., Bain, L.J., Baldwin, W.S., 2004. Differential gene expression in mummichog (Fundulus heteroclitus) following treatment with pyrene and fluoranthene: comparison to a creosote contaminated site. Mar. Environ. Res. 57, 377-395.

Roling, J.A., Bain, L.J., Gardea-Torresdey, J., Bader, J.A., Baldwin, W.S., 2006. Hexavalent chromium reduces larval growth and alters gene expression in mummichogs (Fundulus heteroclitus). Environ. Toxicol. Chem. 25, $2725-2733$.

Roling, J.A., Bain, L.J., Gardea-Torresdey, J., Key, P.B., Baldwin, D., 2007. Using mummichog (Fundulus heteroclitus) arrays to monitor the effectiveness of remediation at a superfund site in Charleston, South Carolina. Environ. Toxicol. Chem. 26, 1205-1213.

Ropson, I.J., Powers, D.A., 1989. The allelic isozymes of hexose-6-phosphate dehydrogenase Isolated from Fundulus heteroclitus - physical characteristics and kinetic properties. Mol. Biol. Evol. 6, 171-185.

Ropson, I.J., Brown, D.C., Powers, D.A., 1990. Biochemical genetics of Fundulus heteroclitus L. VI Geographical variation in the gene frequencies of 15 loci. Evolution 44, 16-26.

Roszell, L.E., Anderson, R.S., 1993. In vitro immunomodulation by pentachlorophenol in phagocytes from an estuarine teleost, Fundulus heteroclitus, as measured by chemiluminescence activity. Arch. Environ. Contam. Toxicol. 25, 492-496.

Roszell, L.E., Anderson, R.S., 1994. Inhibition of phagocytosis and superoxide production by pentachlorophenol in two leukocyte subpopulations from Fundulus heteroclitus. Mar. Environ. Res. 38, 195-206.
Roszell, L.E., Anderson, R.S., 1996. Effect of chronic in vivo exposure to pentachlorophenol on non-specific immune functions in Fundulus heteroclitus. Mar. Environ. Res. 42, 191-194.

Safe, S., 2004. Endocrine disruptors and human health: is there a problem. Toxicology 205, 3-10.

Schlichting, C., Pigliucci, M., 1998. Phenotypic evolution: a reaction norm perspective. Sinauer, Sunderland, Mass.

Schofield, C.J., Ratcliffe, P.J., 2005. Signalling hypoxia by HIF hydroxylases. Biochem. Biophys. Res. Com. 338, 617-626.

Schulte, P.M., 2001. Environmental adaptations as windows on molecular evolution. Comp. Biochem. Physiol. B 128, 597-611.

Schulte, P.M., 2007. Responses to environmental stressors in an estuarine fish: interacting stressors and the impacts of local adaptation. J. Therm. Biol. 32, $152-161$.

Schulte, P.M., Gomez-Chiarri, M., Powers, D.A., 1997. Structural and functional differences in the promoter and $5^{\prime}$ flanking region of $L d h-b$ within and between populations of the teleost Fundulus heteroclitus. Genetics 145, 759-769.

Schulte, P.M., Glemet, H.C., Fiebig, A.A., Powers, D.A., 2000. Adaptive variation in lactate dehydrogenase-B gene expression: role of a stress-responsive regulatory element. Proc. Natl. Acad. Sci. U. S. A. 97, 6597-6602.

Scott, W.B., Crossman, E.J., 1998. Freshwater Fishes of Canada. Galt House Publications Ltd., Oakville, Canada.

Scott, G.R., Richards, J.G., Forbush, B., Isenring, P., Schulte, P.M., 2004a Changes in gene expression in the gills of the euryhaline killifish Fundulus heteroclitus after abrupt salinity transfer. Am. J. Physiol. 287, C300-C309.

Scott, G.R., Rogers, J.T., Richards, J.G., Wood, C.A., Schulte, P.M., 2004b. Intraspecific divergence of ionoregulatory physiology in the euryhaline teleost Fundulus heteroclitus: possible mechanisms of freshwater adaptation. J. Exp. Biol. 207, 3399-3410.

Scott, G.R., Claiborne, J.B., Edwards, S.L., Schulte, P.M., Wood, C.M., 2005 a. Gene expression after freshwater transfer in gills and opercular epithelia of killifish: insight into divergent mechanisms of ion transport. J. Exp. Biol. 208, 2719-2729.

Scott, G.R., Keir, K.R., Schulte, P.M., 2005b. Effects of spironolactone and RU486 on gene expression and cell proliferation after freshwater transfer in the euryhaline killifish. J. Comp. Physiol. B 175, 499-510.

Segal, J.A., Crawford, D.L., 1994. LDH-B enzyme expression: the mechanisms of altered gene expression in acclimation and evolutionary adaptation. Am. J. Physiol. 267, R1150-R1153.

Segal, J.A., Schulte, P.M., Powers, D.A., Crawford, D.L., 1996. Descriptive and functional characterization of variation in the Fundulus heteroclitus $L d h-B$ proximal promoter. J. Exp. Zool. A 275, 355-364.

Segal, J.A., Barnett, J.L., Crawford, D.L., 1999. Functional analyses of natural variation in Sp1 binding sites of a TATA-less promoter. J. Mol. Evol. 49, 736-749.

Selman, K., Wallace, R.A., 1983. Oogenesis in Fundulus heteroclitus III. Vitellogenesis. J. Exp. Zool. A 226, 441-457.

Selman, K., Wallace, R.A., 1986. Gametogenesis in Fundulus heteroclitus. Am. Zool. 26, 173-192.

Semple, J.W., Green, H.J., Schlte, P.M., 2002. Molecular cloning and characterization of two Na/K-ATPase isoforms in Fundulus heteroclitus. Mar. Biotechnol. 4, 512-519.

Shang, E.H.H., Wu, R.S.S., 2004. Aquatic hypoxia is a teratogen and affects fish embryonic development. Environ. Sci. Technol. 38, 4763-4767.

Shang, E.H.H., Yu, R.M.K., Wu, R.S.S., 2006. Hypoxia affects sex differentiation and development, leading to a male-dominated population in zebrafish (Danio rerio). Environ. Sci. Technol. 40, 3118-3122.

Sharp, J.R., Neff, J.M., 1982. The toxicity of mercuric-chloride and methylmercuric chloride to Fundulus heteroclitus embryos in relation to exposure conditions. Environ. Biol. Fish. 7, 277-284.

Sharpe, R.L., MacLatchy, D.L., Courtenay, S.C., Van Der Kraak, G.J., 2004. Effects of a model androgen (methyl testosterone) and a model antiandrogen (cyproterone acetate) on reproductive endocrine endpoints in a short-term adult mummichog (Fundulus heteroclitus) bioassay. Aquat. Toxicol. 67, 203-215.

Shaughnessy, K., Hewitt, M.L., Dubé, M.G., MacLatchy, D.L., 2007. Toxicity identification evaluation of kraft pulp mill condensates associated with 
testosterone depressions in mummichog (Fundulus heteroclitus). Ecotoxicol. Environ. Saf. 67, 140-148.

Shaw, A.J., 1999. The evolution of heavy metal tolerance in plants: adaptations, limits and costs. In: Forbes, V.E. (Ed.), Current topics in ecotoxicology and environmental chemistry. Taylor and Francis, Philadelphia, PA.

Shimizu, A., 2003. Effect of photoperiod and temperature on gonadal activity and plasma steroid levels in a reared strain of the mummichog (Fundulus heteroclitus) during different phases of its annual reproductive cycle. Gen. Comp. Endocrinol. 131, 310-324.

Silva, P., Stoff, J., Field, M., Fine, L., Forrest, J.N., Epstein, F.H., 1977. Mechanism of active chloride secretion by shark rectal gland: role of $\mathrm{Na}-\mathrm{K}-$ ATPase in chloride transport. Am. J. Physiol. 233, F298-F306.

Singer, T.D., Tucker, S.J., Marshall, W.S., Higgins, C.F., 1998. A divergent CFTR homologue: highly regulated salt transport in the euryhaline teleost $F$. heteroclitus. Am J Physiol 274, C715-C723.

Skinner, M.A., Courtenay, S.C., Parker, W.R., Curry, R.A., 2005. Site fidelity of mummichogs (Fundulus heteroclitus) in an Atlantic Canadian estuary. Water Qual. Res. J. Can. 40, 288-298.

Smith, G., Weis, J., 1997. Predator/prey interactions of mummichogs: effects of living in a polluted environment. J. Exper. Mar. Biol. Ecol. 209, 75-87.

Smith, K.J., Able, K.W., 2003. Dissolved oxygen dynamics in salt marsh pools and its potential impacts on fish assemblages. Mar. Ecol. Prog. Ser. 258, 223-232.

Spalding, M.G., Bancroft, G.T., Forrester, D.J., 1993. The epizootiology of eustrongylidosis in wading birds (Ciconiiformes) in Florida. J. Wildl. Dis. 29, $237-249$.

Stamatoyannopoulos, J.A., 2004. The genomics of gene expression. Genomics 84, 449-457.

Stegeman, J.J., 1978. Influence of environmental contamination on cytochrome P-450 mixed-function oxygenases in fish: implications for recovery in the Wild Harbor Marsh. J. Fish. Res. Board Can. 35, 668-674.

Stegeman, J.J., 1979. Temperature influence on basal activity and induction of mixed function oxygenase activity in Fundulus heteroclitus. J. Fish. Res. Board Can. 36 I4000-I1405.

Stierhoff, K.L., Targett, T.E., Grecay, P.A., 2003. Hypoxia tolerance of the mummichog: the role of access to the water surface. J. Fish Biol. 63, 580-592.

Storz, J.F., Dubach, J.M., 2004. Natural selection drives altitudinal divergence at the albumin locus in deer mice, Peromyscus maniculatus. Evolution 58, $1342-1352$.

Sumpter, J.P., Johnson, A.C., 2005. Lessons from endocrine disruption and their application to other issues concerning trace organics in the aquatic environment. Environ. Sci. Technol. 39, 4321-4332.

Swartz, R.C., 1999. Consensus sediment quality guidelines for polycyclic aromatic hydrocarbon mixtures. Environ. Toxicol. Chem. 18, 780-787.

Taniguchi, Y., Takeda, S., Furutani-Seiki, M., Kamei, Y., Todo, T., Sasado, T., Deguchi, T., Kondoh, H., Mudde, J., Yamazoe, M., Hidaka, M., Mitani, H., Toyoda, A., Sakaki, Y., Plasterk, R.H.A., Cuppen, E., 2006. Generation of medaka gene knockout models by target-selected mutagenesis. Genome Biol. 7, R116.

Tarrant, A.M., Greytak, S.R., Callard, G.V., Hahn, M.E., 2006. Estrogen receptor-related receptors in the killifish Fundulus heteroclitus: diversity, expression, and estrogen responsiveness. J. Mol. Endocrinol. 37, $105-120$.

Taylor, M., Feyereisen, R., 1996. Molecular biology and evolution of resistance to toxicants. Mol. Biol. Evol. 13, 719-734.

Taylor, M.H., 1986. Environmental and endocrine influences on reproduction of Fundulus heteroclitus. Am. Zool. 26, 159-171.

Taylor, M.H., 1991. Entrainment of the semilunar reproductive cycle of Fundulus heteroclitus. In: Scott, A.P., Sumpter, J.P., Kime, D.E., Rolfe, M.S. (Eds.), Reproductive Physiology of Fish, vol. 91. Fish Symposium, Sheffield, United Kingdom, pp. 157-159.

Taylor, M.H., 1999. A suite of adaptations for intertidal spawning. Am. Zool. 39, 313-320.

Taylor, M.H., DiMichele, L., 1983. Spawning site utilization in a Delaware population of Fundulus heteroclitus (Pisces: Cyprinodontidae). Copeia 1983, 719-725.

Taylor, M.H., Leach, G.J., DiMichele, L., Levilan, W.M., Jacob, W.F., 1979. Lunar spawning cycle in the mummichog, Fundulus heteroclitus (Pisces: Cyprinodontidae). Copeia 1979, 291-297.
Teal, J.M., Farrington, J.W., Burns, K.A., Stegeman, J.J., Tripp, B.W., Woodin, B., Phinney, C., 1992. The West Falmouth oil spill after twenty years- fate of fuel- oil compounds and effects on animals. Mar. Pollut. Bull. 24, 607-614.

Timme-Laragy, A.R., Levin, E.D., Di Giulio, R.T., 2006. Developmental and behavioral effects of embryonic exposure to the polybrominated diphenylether mixture DE-71 in the killifish (Fundulus heteroclitus). Chemosphere 62, 1097-1104.

Timmerman, C., Chapman, L.J., 2004. Patterns of hypoxia in a coastal salt marsh: implications for ecophysiology of resident fishes. Fla. Sci. 67, 80-91.

Tirindelli, J., 2007. A comparison of immunogenetic profiles between PCB contaminated and reference killifish populations. Master of Science. San Francisco State University, San Francisco.

Ton, C., Stamatiou, D., Liew, C.C., 2003. Gene expression profile of zebrafish exposed to hypoxia during development. Physiol. Genomics 13, 97-106.

Toomey, B.H., Bello, S., Hahn, M.E., Cantrell, S., Wright, P., Tillitt, D.E., Di Giulio, R.T., 2001. 2,3,7,8-Tetrachlorodibenzo-p-dioxin induces apoptotic cell death and cytochrome P4501A expression in developing Fundulus heteroclitus embryos. Aquat. Toxicol. 53, 127-138.

Toppin, S.V., Heber, M., Weis, J.S., Weis, P., 1987. Changes in reproductive biology and life history in Fundulus heteroclitus in a polluted environment. In: Vernberg, W., Calabrese, A., Thurberg, F., Vernberg, F.J. (Eds.), Pollution Physiology of Estuarine Organisms. University of South Carolina Press, Columbia, SC.

Towle, D.W., Gilman, M.E., Hempel, J.D., 1977. Rapid modulation of gill $\mathrm{Na}^{+} \mathrm{K}^{+}$-dependent ATPase activity during acclimation of the killifish Fundulus heteroclitus to salinity change. J. Exp. Zool. 202, 179-186.

Tremblay, G.B., Kunath, T., Bergeron, D., Lapointe, L., Champigny, C., Bader, J.A., Rossant, J., Giguere, V., 2001. Diethylstilbestrol regulates trophoblast stem cell differentiation as a ligand of orphan nuclear receptor ERR beta. Genes Dev. 15, 833-838.

Trinkaus, J.P., 1963. The cellular basis of Fundulus epiboly: adhesivity of blastula and gastrula cells in culture. Dev. Biol. 7, 513-532.

Trinkaus, J.P., 1998. Gradient in convergent cell movement during Fundulus gastrulation. J. Exp. Zool. A 281, 328-335.

Urushitani, H., Shimizu, A., Katsu, Y., Iguchi, T., 2002. Early estrogen exposure induces abnormal development of Fundulus heteroclitus. J. Exp. Zool. A 293, 693-702.

Urushitani, H., Nakai, M., Inanaga, H., Shimohigashi, Y., Shimizu, A., Katsu, Y., Iguchi, T., 2003. Cloning and characterization of estrogen receptor alpha in mummichog, Fundulus heteroclitus. Mol. Cell. Endocrinol. 203, 41-50.

Van Beneden, R.J., Powers, D.A., 1985. The isozymes of glucosephosphate isomerase (Gpi-A2 and Gpi-B2) from the teleost fish Fundulus heteroclitus (L). J. Biol. Chem. 260, 4596-4603.

Van Beneden, R.J., Powers, D.A., 1989. Structural and functional differentiation of two clinically distributed glucosephosphate isomerase allelic isozymes from the teleost Fundulus heteroclitus. Mol. Biol. Evol. 6, 155-170.

Van der Meer, D.L.M., van den Thillart, G.E.E.J.M., Witte, F., de Bakker, M.A.G., Besser, J., Richardson, M.K., Spaink, H.P., Leito, J.T.D., Bagowski, C.P., 2005. Gene expression profiling of the long-term adaptive response to hypoxia in the gills of adult zebrafish. Am. J. Physiol. 289, R1512-R1519.

Van Praag, D., Farber, S.J., Minkin, E., Primor, N., 1987. Production of eicosanoids by the killifish gills and opercular epithelia and their effect on active transport of ions. Gen. Comp. Endocrinol. 67, 50-57.

Van Veld, P.A., Westbrook, D.J., 1995. Evidence for depression of cytochrome P4501A in a population of chemically resistant mummichog (Fundulus heteroclitus). Environ. Sci. 3, 221-234.

Van Veld, P.A., Ko, U.C., Vogelbein, W.K., Westbrook, D.J., 1991. Glutathione$s$-transferase in intestine, liver and hepatic lesions of mummichog (Fundulus heteroclitus) from a creosote contaminated environment. Fish Physiol. Biochem. 9, 369-376.

Van Veld, P.A., Vogelbein, W.K., Smolowitz, R., Woodin, B.R., Stegeman, J.J., 1992. Cytochrome P450Ia1 in hepatic lesions of a teleost fish (Fundulus heteroclitus) collected from a polycyclic aromatic hydrocarbon-contaminated site. Carcinogenesis 13, 505-507.

Van Veld, P.A., Vogelbein, W.K., Cochran, M.K., Goksoyr, A., Stegeman, J.J., 1997. Route-specific cellular expression of cytochrome P4501A (CYP1A) in fish (Fundulus heteroclitus) following exposure to aqueous and dietary benzo[a]pyrene. Toxicol. Appl. Pharmacol. 142, 348-359. 
Van Veld, P.A., Nacci, D., in press. Toxicity resistance. In: Di Giulio, R.T., Hinton, D.E. (Eds.), The Toxicology of Fishes, Taylor and Francis, Boca Raton, FL.

Vigouroux, Y., McMullen, M., Hittinger, C.T., Houchins, K., Schulz, L., Kresovich, S., Matsuoka, Y., Doebley, J., 2002. Identifying genes of agronomic importance in maize by screening microsatellites for evidence of selection during domestication. Proc. Natl. Acad. Sci. U. S. A. 99, 9650-9655.

Virani, N.A., Rees, B.B., 2000. Oxygen consumption, blood lactate and interindividual variation in the gulf killifish, Fundulus grandis, during hypoxia and recovery. Comp. Biochem. Physiol. A 126, 397-405.

Vogelbein, W., Zwerner, D.E., Unger, M.A., Smith, C.L., Fournie, J.W., 1997. Hepatic and extra-hepatic neoplasms in a teleost fish from a polycyclic aromatic hydrocarbon-contaminated habitat in Chesapeake Bay, USA. In: Rossi, L., Richardson, R., Harshbarger, J. (Eds.), Spontaneous Animal Tumors: A Survey. Press Point di Abbiategrasso, Milan, Italy, pp. 55-64.

Vogelbein, W.K., Fournie, J.W., 1994. Ultrastructure of normal and neoplastic exocrine pancreas in the mummichog, Fundulus heteroclitus. Toxicol. Pathol. 22, 248-260.

Vogelbein, W.K., Zwerner, D.E., 2002. Prevalence, histopathology and ultrastructure of vascular neoplasms in mummichogs (Fundulus heteroclitus) from a creosote-contaminated site. Proceedings: 4th International Symposium of Aquatic Animal Health, New Orleans, LA, USA.

Vogelbein, W.K., Fournie, J.W., Van Veld, P.A., Huggett, R.J., 1990. Hepatic neoplasms in the mummichog Fundulus heteroclitus from a creosotecontaminated site. Cancer Res. 50, 5978-5986.

Vogelbein, W.K., Fournie, J.W., Cooper, P.S., Van Veld, P.A., 1999. Hepatoblastomas in the mummichog, Fundulus heteroclitus (L.), from a creosote-contaminated environment: a histologic, ultrastructural and immunohistochemical study. J. Fish Dis. 22, 419-431.

Vogelbein, W.K., Unger, M.A., 2006. Liver carcinogenesis in a non-migratory fish: the association with polycyclic aromatic hydrocarbon exposure. Bull. Eur. Ass. Fish. Pathol. 26, 31-37.

Voight, B.F., Kudaravalli, S., Wen, X.Q., Pritchard, J.K., 2006. A map of recent positive selection in the human genome. Plos Biol. 4, 446-458.

Voyer, R.A., Hennekey, R.J., 1972. Effects of dissolved oxygen on two life stages of the mummichog. Prog. Fish-Cult. 34, 222-225.

Wang, L., Scheffler, B.E., Willett, K.L., 2006. CYP1C1 messenger RNA expression is inducible by benzo[ $a]$ pyrene in Fundulus heteroclitus embryos and adults. Toxicol. Sci. 93, 331-340.

Wannamaker, C.M., Rice, J.A., 2000. Effects of hypoxia on movements and behavior of selected estuarine organisms from the southeastern United States. J. Exp. Mar. Biol. Ecol. 249, 145-163.

Ward, A.J.W., Hoare, D.J., Couzin, I.D., Broom, M., Krause, J., 2002. The effects of parasitism and body length on positioning within wild fish shoals. J. Animal Ecol. 71, 10-14.

Wassenberg, D.M., Di Giulio, R.T., 2004a. Synergistic embryo toxicity of polycyclic aromatic hydrocarbons aryl hydrocarbon receptor agonists with cytochrome P4501A inhibitors in Fundulus heteroclitus. Environ. Health Perspect. 112, 1658-1664.

Wassenberg, D.M., Di Giulio, R.T., 2004b. Teratogenesis in Fundulus heteroclitus embryos exposed to a creosote-contaminated sediment extract and CYP1A inhibitors. Mar. Environ. Res. 58, 163-168.

Wassenberg, D.M., Nerlinger, A.L., Battle, L.P., Di Giulio, R.T., 2005. Effects of the polycyclic aromatic hydrocarbon heterocycles, carbazole and dibenzothiophene, on in vivo and in vitro CYP1A activity and polycyclic aromatic hydrocarbon-derived embryonic deformities. Environ. Toxicol. Chem. 24, 2526-2532.

Weaver, G., 1982. PCB pollution in the New Bedford, Massachusetts, area: a status report. In: O.o.C.Z.M. (Ed.), Executive Office of Environmental Affairs. Massachusetts Zone Management.

Weis, J., Khan, A., 1991. Reduction in prey capture ability and condition in mummichogs from a polluted habitat. Trans. Amer. Fish. Soc. 120, 127-129.

Weis, J., Weis, P., 1989. Tolerance and stress in a polluted environment: the case of the mummichog. Bioscience 39, 89-95.

Weis, J., Weis, P., Heber, M., Vaidya, S., 1981. Methylmercury tolerance of killifish (Fundulus heteroclitus) embryos from a polluted vs non-polluted environment. Mar. Biol. 65, 283-287.
Weis, J.S., 2002. Tolerance to environmental contaminants in the mummichog, Fundulus heteroclitus. Hum. Ecol. Risk Assess. 8, 933-953.

Weis, J.S., Weis, P., Heber, M., 1982. Variation in response to methylmercury by killifish (Fundulus heteroclitus) embryos. In: Pearson, J.G., Foster, F., Bishop, W.E. (Eds.), Aquatic Toxicology and Hazard Assessment: Fifth Conference, ASTM STP 766. American Society for Testing and Materials, Philadelphia, PA.

Weis, J.S., Smith, G., Zhou, T., Santiago-Bass, C., Weis, P., 2001. Effects of contaminants on behavior: biochemical mechanisms and ecological consequences. Bioscience 51, 209-217.

Weis, J.S., Samson, J., Zhou, T., Skurnick, J., Weis, P., 2003. Evaluating prey capture by larval mummichogs (Fundulus heteroclitus) as a potential biomarker for contaminants. Mar. Environ. Res. 55, 27-38.

Weis, P., Weis, J.S., 1974. Cardiac malformations and other effects due to insecticides in embryos of the killifish, Fundulus heteroclitus. Teratology 10, 263-267.

Weis, P., Weis, J.S., 1977. Methylmercury teratogenesis in the killifish, Fundulus heteroclitus. Teratology 16, 317-325.

Wenger, R.H., Stiehl, D.P., Camenisch, G., 2005. Integration of oxygen signaling at the consensus HRE. Science STKE 2005 (306), re12 (Oct 18).

Whitehead, A., Crawford, D.L., 2005. Variation in tissue-specific gene expression among natural populations. Genome Biol. 6, R13.

Whitehead, A., Crawford, D.L., 2006a. Neutral and adaptive variation in gene expression. Proc. Natl. Acad. Sci. U. S. A. 103, 5425-5430.

Whitehead, A., Crawford, D.L., 2006b. Variation within and among species in gene expression: raw material for evolution. Mol. Ecol. 15, 1197-1211.

Wienholds, E., Schulte-Merker, S., Walderich, B., Plasterk, R.H.A., 2002. Target-selected inactivation of the zebrafish rag1 gene. Science 297, 99-102.

Wienholds, E., van Eeden, F., Kosters, M., Mudde, J., Plasterk, R.H.A., Cuppen, E., 2003. Efficient target-selected mutagenesis in zebrafish. Genome Res. $13,2700-2707$.

Willett, K., Steinberg, M., Thomsen, J., Narasimhan, T.R., Safe, S., McDonald, S., Beatty, K., Kennicutt, M.C., 1995. Exposure of killifish to benzo[a] pyrene: comparative metabolism, DNA adduct formation and aryl hydrocarbon (Ah) receptor agonist activities. Comp. Biochem. Physiol. B $112,93-103$.

Winn, R.N., Van Beneden, R.J., Burkhart, J.G., 1995. Transfer, methylation and spontaneous mutation frequency of $\Phi X 174 \operatorname{am} 3 \operatorname{cs} 70$ sequences in medaka (Oryzias latipes) and mummichog (Fundulus heteroclitus): implications for gene-transfer and environmental mutagenesis in aquatic species. Mar. Environ. Res. 40, 247-265.

Winn, R.N., Norris, M.B., Brayer, K.J., Muller, S.L., Torres, C., 2000. Detection of mutations in transgenic fish carrying a lambda bacteriophage cII transgene target. Proc. Natl. Acad. Sci. U. S. A. 97, 12655-12660.

Wood, C.M., Marshall, W.S., 1994. Ion balance, acid-base regulation and chloride cell function in the common killifish, Fundulus heteroclitus - a euryhaline estuarine teleost. Estuaries 17, 34-52.

Wu, R.S.S., Zhou, B.S., Randall, D.J., Woo, N.Y.S., Lam, P.K.S., 2003. Aquatic hypoxia is an endocrine disruptor and impairs fish reproduction. Environ. Sci. Technol. 37, 1137-1141.

Yang, G., 2003. Analysis of evolved resistance and population genetic structure of the estuarine teleost Fundulus heteroclitus (Atlantic killifish) using AHR1. Environmental Science and Public Policy, Senior undergraduate thesis. Harvard College, Cambridge, MA.

Zhao, J., Mak, P., Tchoudakova, A., Callard, G., Chen, S., 2001. Different catalytic properties and inhibitor responses of the goldfish brain and ovary aromatase isozymes. Gen. Comp. Endocrinol. 123, 180-191.

Zhou, T., Rademacher, D.J., Steinpreis, R.E., Weis, J.S., 1999. Neurotransmitter levels in two populations of larval Fundulus heterclitus after methylmercury exposure. Comp. Biochem. Physiol. C, Comp. Pharmacol. Toxicol. 124, 287-294.

Zhou, T., Scali, R., Weis, J.S., 2001. Effects of methylmercury on ontogeny of prey capture ability and growth in three populations of larval Fundulus heteroclitus. Arch. Environ. Contam. Toxicol. 41, 47-54. 